\title{
Systematics of the mayfly taxon Acentrella (Ephemeroptera: Baetidae), with description of new Asian and African species
}

\author{
Систематика поденок таксона Acentrella (Ephemeroptera: \\ Baetidae) с описанием новых видов из Азии и Африки
}

\author{
Nikita J. Kluge ${ }^{1} \&$ Eugenia A. Novikova ${ }^{2}$ \\ Н.Ю. КАюге ${ }^{1}$ Е.А. Новикова ${ }^{2}$
}

\footnotetext{
${ }^{1}$ Department of Entomology, St. Petersburg State University, Universitetskaya nab., 7/9, St. Petersburg 199034, Russia. E-mail: kluge@FK13889.spb.edu. Website: http://www.insecta.bio.pu.ru

${ }^{1}$ Кафедра энтомологии, биолого-почвенный факультет, С.-Петербургский государственный университет, Университетская наб., 7/8, С.-Петербург 199034, Россия.

2 Department of Ichthyology and Hydrobiology, St. Petersburg State University, Vasilievskiy Ostrov, 16th line, 29, St. Petersburg 199034, Russia.

${ }^{2}$ Кафедра ихтиологии и гидробиологии, биолого-почвенный факультет, С.-Петербургский государственный университет, 16 линия ВО, 29, С.-Петербург 199034, Россия.
}

KEY WORDS: systematics, morphology, Ephemeroptera, cladoendesis, microlepides, unistyliger, penial bridge, gonovectis, Protopatellata, Anteropatellata, Baetovectata, Baetungulata, Baetofemorata, Baetosternata, Acentrellini, Acentrella, Jubabaetis, Tanzaniops, Liebebiella, Platybaetis, new species.

КЛЮЧЕВЫЕ СЛОВА: систематика, морфология, Ephemeroptera, кладоэндезис, микролепиды, унистилигер, гоновектис, Protopatellata, Anteropatellata, Baetovectata, Baetungulata, Baetofemorata, Baetosternata, Acentrellini, Acentrella, Jubabaetis, Tanzaniops, Liebebiella, Platybaetis, новые виды.

ABSTRACT. This paper continues publications on phylogenetic analysis of Ephemeroptera according to the approach, which is named here "cladoendesis". A new term "microlepides" is suggested for peculiar cuticular texture. Autapomorphies of Liberevenata in genital structure are described, new terms "unistyliger", "penial bridge" and "gonovectis" are introduced. Autapomorphy of Anteropatellata in tibial structure is re-defined, and a new circumscriptional taxon name Protopatellata taxon $\mathbf{n}$. is established. In Anteropatellata, the following new subsequently subordinated holophyletic taxa are established and characterized: Baetovectata taxon n., Baetungulata taxon n., Baetofemorata taxon n. and Baetosternata taxon $\mathbf{n}$. A new typified name Acentrellini tribus n. is introduced, to form a hierarchical name Acentrella/fg1 for a taxon belonging to Baetofemorata-non-Baetosternata. System of Acentrella/fg1 is revised. All Holarctic representatives of Acentrella/fg1 are temporarily placed to a plesiomorphon Acentrella/fg2. Key to larvae and male imagoes of Palearctic species of Acentrella/fg2 is given; they are divided into four species groups. Group lapponica is a plesiomorphon, characterized by presence of hind wings; larvae, subimagoes, imagoes and eggs are described for lapponica [Acentrella], charadra [Acentrella] and chantauensis [Baetis]; feropagus [Acentrel$l a]$, known as larvae only, is redescribed basing on material from far north-east of Russia; comments on joosti [Baetis] are given. Group fenestratum includes a single speciesfenestratum [Pseudocloeon]; larvae, subimagoes, imagoes and eggs are described. Group inexpectatum includes 2 species - inexpectatum [Pseudocloeon] and gnom [Pseudocloeon]; their larvae, subimagoes, imagoes and eggs are described. Group sibiricum includes 3 species - sibiricum [Pseudocloeon], diptera sp.n. [Acentrella] (new species from Siberia and Russian Far East) and scabriventris sp.n. [Acentrella] (new species from Kyrgyzstan and Tajikistan); their larvae, subimagoes, imagoes and eggs are described. African and Oriental representatives of Acentrella/fg1 constitute a holophyletic taxon Jubabaetis/g1 characterized by an autapomorphy in structure of left mola. Jubabaetis/g1 is divided to African taxon Tanzaniops/g(1) and Oriental taxon Jubabaetis/g2. A new species lunamontana sp.n. [Acentrella (Tanzaniops)] is described as larvae, subimagoes and imagoes from Uganda. Holophyletic taxon Jubabaetis/g2 is divided into a plesiomorphon Liebebiella/g(1) and holophyletic taxa Jubabaetis/g3 and Platybaetis/g(1). Three species of Liebebiella/g(1) are described as larvae, subimagoes and imagoes: verum [Pseudocloeon] (= deigma [Liebebiella], syn.n.), bispinosa sp.n. [Acentrella (Liebebiella)] and cylindroculata sp.n. [Acentrella (Liebebiella)] (new species from Sulawesi). Two species of Platybaetis/g(1) from Sulawesi are described as larvae, subimagoes and imagoes: mamasae sp.n. [Platybaetis] and wallacei [Platybaetis].

РЕЗЮМЕ. Данная статья продолжает серию публикаций по анализу филогении подёнок в соответствии с подходом, который назван здесь “кладоэндезис”. Новый термин “микролепиды” предложен для 
особого рельефа кутикулы. Описываются аутапоморфии Liberevenata в строении гениталий и вводятся новые термины “унистилигер”, “мост пениса" и "гоновектис". Переописана аутапоморфия Anteropatellata в строении голени и установлен новый таксон Protopatellata taxon n. В составе Anteropatellata установлены и охарактеризованы новые последовательно соподчинённые таксоны Baetovectata taxon n., Baetungulata taxon n., Baetofemorata taxon n. и Baetosternata taxon n. Вводится новое типифицированное название Acentrellini tribus n., чтобы образовать иерархическое название Acentrella/fg1 для таксона, относящегося к Baetofemorata-non-Baetosternata. Пересматривается система Acentrella/fg1. Все голарктические представители Acentrella/fg1 временно помещаются в плезиоморфон Acentrella/fg2. Даются ключи для определения личинок и самцов имаго палеарктических видов Acentrella/fg2, которые делятся на 4 группы видов. Группа lapponica является плезиоморфоном, характеризующимся наличием задних крыльев; описываются личинки, субимаго, имаго и яйца lapponica [Acentrella], charadra [Acentrella] и chantauensis [Baetis]; feropagus [Acentrella], известный только по личинкам, переописывается по материалу с крайнего северо-востока России; даны замечания о joosti [Baetis]. Группа fenestratum включает единственный вид fenestratum [Pseudocloeon]; описываются его личинки, субимаго, имаго и яйца. Группа inexpectatum включает 2 вида - inexpectatum [Pseudocloeon] и gnom [Pseudocloeon]; описываются их личинки, субимаго, имаго и яйца. Группа sibiricum включает 3 вида - sibiricum [Pseudocloeon], diptera sp.n. [Acentrella] (новый вид из Сибири и Дальнего Востока) и scabriventris sp.n. [Acentrella] (новый вид из Киргизии и Таджикистана); описываются их личинки, субимаго, имаго и яйца. Африканские и ориентальные представители Acentrella/fg1 образуют голофилетический таксон Jubabaetis/g1, характеризующийся аутапоморфией в строении левой молы. Jubabaetis/g1 делится на африканский таксон Tanzaniops/g(1) и ориентальный таксон Jubabaetis/ g2. По личинкам, субимаго и имаго из Уганды описывается новый вид lunamontana sp.n. [Acentrella (Tanzaniops)]. Голофилетический таксон Jubabaetis/ g2 делится на плезиоморфон Liebebiella/g(1) и голофилетические таксоны Jubabaetis/g3 и Platybaetis/g(1). По личинкам, субимаго и имаго описываются три новых вида Liebebiella/g(1): verum [Pseudocloeon] (= deigma [Liebebiella], syn.n.), bispinosa sp.n. [Acentrella (Liebebiella)] и cylindroculata sp.n. [Acentrella (Liebebiella)] (новые виды из Сулавеси). По личинкам, субимаго и имаго из Сулавеси описываются два вида Platybaetis/g(1): mamasae sp.n. [Platybaetis] и wallacei [Platybaetis].

\section{Introduction}

The most comprehensive analysis of mayfly phylogeny is given in the book "The phylogenetic system of
Ephemeroptera" [Kluge, 2004]. Updated electronic version of this monograph is available from "www.insecta.bio.pu.ru". The method of phylogenetic analysis used there can be named cladoendesis - i.e., "branch-coupling" (from Greek $\kappa \lambda \alpha \delta o \zeta+\varepsilon v-\delta \varepsilon \sigma 1 \varsigma$ ). Cladoendesis is based on a specially elaborated rational text layout and a powerful, rank-free, dual nomenclature system [Kluge, 2010]. This allows to arrange all characters among taxa, make clear links between characters of subordinated and higher taxa, clarify phylogenetic significance of characters, adequately use in phylogenetic analysis all know apomorphies, and find ways to discover new apomorphies [Kluge, 2000; 2004]. Cladoendesis is opposed to a non-scientific approach of counting characters and calculating parsimony (which is not compatible with any modern evolutionary theory). "The phylogenetic system of Ephemeroptera" gives detailed cladoendetic system of all mayflies except for Leptophlebiidae and Baetidae. The present paper starts a series of publications on cladoendesis of Baetidae.

For most species, described in this paper, imagoes were reared from larvae in field conditions during trips to various regions of Russian Federation (Urals, Siberia, Far East), Kyrgyzstan, Tajikistan, Mongolia, Indonesia (Java, Sulawesi) and Uganda. All material, including holotypes and paratypes of new species, is permanently deposited in the Zoological Institute of Russian Academy of Sciences (Saint Petersburg, Russia); temporarily locates in the Department of Entomology of Saint Petersburg State University. In the lists of material examined, the following arbitrary signs are used: $\mathbf{L}-$ larva; S - subimago; I — imago; L-S-I $\sigma^{\top}$ - male imago reared from larva, with larval and subimaginal exuviae; L-S-I + - female imago reared from larva, with larval and subimaginal exuviae; L-S $\sigma^{7}$ - male subimago reared from larva, with subimaginal exuviae; $\mathbf{L} / \mathbf{S} \sigma^{7}$ - male subimago extracted from mature larva.

Before description of taxa, it is necessary to give two comments: (1) on status of the old generic name Pseudocloeon and (2) on a new term for description of color patterns.

\section{A. General remarks}

\section{A.1. Status of the generic name Pseudocloeon}

Most species, which are here attributed to Acentrella/fg1, have been originally described in the genus Pseudocloeon. The generic name Pseudocloeon Klapalek, 1905 is older than Acentrella Bengtsson, 1912. Originally, the genus Pseudocloeon was characterized as having fore wing venation as in Baetis [see below, Baetovectata (1)], but lacking hind wings, as Cloeon. In the original description 4 species are mentioned as belonging to the genus Pseudocloeon: kraepelini Klapalek, 1905 [Pseudocloeon], dubia Walsh, 1862 [Cloe], oldendorfii Weyenbergh, 1883 [Oxycypha] and an unnamed species from Ceylon — "Cloeon sp." described by Eaton, 1883-1888: 182. The type species originally had not been designated; basing on the fact that only one of these species — Pseudocloeon kraepelini — was referred in the original description as binomen with the 
generic name "Pseudocloeon", this species is regarded as the type species of the generic name Pseudocloeon by monotypy. As it was discovered later, loss of hind wings took place independently in many non-related taxa within Baetovectata [Novikova \& Kluge, 1987; Waltz \& McCafferty, 1987a-b]; so the genus Pseudocloeon, as characterized and outlined by Klapalek, is polyphyletic. Recently this polyphyletic group is split into a number of smaller, more natural taxa. The question, to which of these taxa the old name Pseudocloeon should be applied, remains to be opened. The type species Pseudocloeon kraepelini was described basing on specimens, collected by Karl Kraepelin 24.II-12.III.1904 in Buitenzorg (now Bogor) in Java. Details of this trip can be learned from the paper by Weidner [1972]. After this, nobody vas able to collect this species. The type material is deposited in Zoologisches Museum in Hamburg. Lectotype was designated and redescribed by Waltz and McCafferty in 1985; its photos, made by Dr Ralph Peters in 2009, are available from web <http:// www.insecta.bio.pu.ru/z/Eph-spp/fig/photokraepelini(Pseudocloeon)-typi.htm $>$. Waltz and McCafferty [1985] regarded this species to belong to Labiobaetis, and on this base they synonymized Labiobaetis Novikova \& Kluge, 1987 with Pseudocloeon Klapalek, 1905 . This synonymy is wrong, because shape of gonostyli of $P$. kraepelini is quite different from that of Labiobaetis. In order to clarify situation, we tried to collect this species. 24-26.II.2008 V. Ivanov and S. Melnitsky collected mayflies in Bogor, paying special attention to two-winged baetids; 6-11.VIII.2009 N. Kluge and L. Sheyko reared many imagoes from larvae collected in Cipanas and Cibodas, $30 \mathrm{~km}$ south-east from Bogor. Among the species collected, there are several ones agreeing with the diagnosis of Pseudocloeon, but no one of them is conspecific with the lectotype of $P$. kraepelini. The most common species of that region is verum Müller-Liebenau, 1982 [Pseudocloeon] (see below); it is widely distributed in Indochina, Sumatra, Java, Bali and Lombok; its larvae inhabit various kinds of current waters, clean and polluted. Numerous adults of this species were collected in botanic garden in center of Bogor. Ulmer [1939] mixed imagoes of this species with $P$. kraepelini, and MüllerLiebenau [1981] designated male imaginal specimen of this species as a lectotype of $P$. kraepelini. This designation is invalid, because the specimen does not belong to the type series [Waltz \& McCafferty, 1985]. These two species, verum [Pseudocloeon] and kraepelini [Pseudocloeon], have similar shape of gonostyli, but differ by shape of anteronotal protuberance and structure of gonovectes. Gonovectes of kraepelini [Pseudocloeon] are intensively pigmented, thick and bent under blunt angle; unlike them, gonovectes of verum [Pseudocloeon] are colorless, very thin, bent under acute angle and undulate (Fig. 149).

\section{A.2. Homology of some color marks}

Among various color marks, some are connected with muscle insertions and, thus, can be well homologized. A mark on cuticle, corresponding to area of muscle insertion is termed here sigillum (plural sigilla) — a term currently used for spiders, mites and some insects.

Abdominal terga and sterna of larval and adult mayflies often have a pair of medioanterior sigilla and a pair of medioposterior sigilla, which correspond to anterior insertions of two pairs of the most median longitudinal muscles, whose posterior ends are attached to the anterior margin of the next segment; the pair of muscles arising from medioposterior sigilla are the outermost among longitudinal abdominal muscles, and the pair of muscles arising from medioanterior sigilla locate just under them (Fig. 190); other median longitudinal muscles locate deeper. Both medioanterior and medioposterior sigilla are present on each of $1^{\text {st }}-9^{\text {th }}$ abdominal tergum and $2^{\text {nd }}-8^{\text {th }}$ abdominal sternum; $9^{\text {th }}$ sternum has a single (medioanterior) pair of sigilla, from which arise muscles, going to medio-anterior junction of paraprocts (mIX-X on Fig. 3). The medioanterior sigilla are often elongate-oblique, while the medioposterior sigilla are often roundish (Fig. 99); sometimes shape of these sigilla is different (Figs 110, 134). Color of the medioanterior and medioposterior sigilla differs among taxa and stages of development: they can be either darker than background - i.e., represent maculae (Figs 110, 134, 190), or lighter than background - i.e., represent blanks; sometimes their color is the same as background - i.e., they are not expressed (Fig. 191).

Besides abdomen, characteristic sigilla occur on some other parts of the body. Particularly, pronotum can have characteristic sigilla of composite shape (Fig. 133).

\section{B. Systematic position of Acentrella/fg1 and morphological notes}

Genus-group names mentioned below have the following authorsips: Acanthametropus Tshernova, 1948; Acentrella Bengtsson, 1912; Acerpenna Waltz \& McCafferty, 1987; Afrobaetodes Demoulin, 1970; Afroptiloides Gillies, 1990; Afroptilum Gillies, 1990; Alainites Waltz \& McCafferty (in Waltz, McCafferty \& Thomas), 1994; Ameletopsis Phillips, 1930; Ameletus Eaton, 1885; Americabaetis Kluge, 1992; Ametropus Albarda, 1878; Andesiops Lugo-Ortiz \& McCaffery, 1999; Aturbina Lugo-Ortiz \& McCafferty, 1996; Baetiella Ueno, 1931; Baetis Leach, 1815; Baetodes Needham \& Murphy, 1924; Baetopus Keffermüller, 1960; Bungona Harker, 1957; Callibaetis Eaton, 1881; Camelobaetidius Demoulin, 1966; Caribaetis Kluge, 1992; Centroptella Braasch \& Soldan, 1980; Centroptiloides Lestage, 1918; Centroptilum Eaton, 1869; Chane Nieto, 2003; Cheleocloeon Wuillot \& Gillies, 1993; Chopralla Waltz \& McCafferty, 1987; Cloeodes Traver, 1938; Cloeon Leach, 1815; Dactylobaetis Traver \& Edmunds, 1968; Deceptiviosa Lugo-Ortiz \& McCafferty, 1999; Demoreptus Lugo-Ortiz \& McCafferty, 1997; Diphetor Waltz \& McCafferty, 1987; Dipteromimus McLachlan, 1875; Echinobaetis Mol, 1989; Edmundsiops Lugo-Ortiz \& McCaffery, 1999; Ephemera Linnaeus, 1758; Ephemerella Walsh, 1862; Fallceon Waltz \& McCafferty, 1987; Glossidion Lugo-Ortiz \& McCafferty, 1998; Guajirolus Flowers, 1985; Hemipannota Elouard, Gillies \& Wuillot, 1990; Heterocloeon McDunnough, 1925; Intercloeon Kluge \& Novikova, 1992; Jubabaetis Müller-Liebenau, 1980; Labiobaetis Novikova \& Kluge, 1987; Leptophlebia Westwood, 1840; Liebebiella Waltz \& McCafferty, 1987; Mayobaetis Waltz \& McCafferty, 1985; Metamonius Eaton, 1885; Metretopus Eaton, 1901; Micksiops McCafferty, LugoOrtiz \& Barber-James, 1997; Nanomis Lugo-Ortiz \& McCaffery, 
1999; Nesameletus Tillyard, 1933; Nigrobaetis Kazlauskas (in Novikova \& Kluge), 1987; Offadens Lugo-Ortiz \& McCafferty, 1998 Oniscigaster McLachlan, 1873; Ophelmatostoma Waltz \& McCafferty, 1987; Palaeocloeon Kluge, 1997; Papuanatula Lugo-Ortiz \& McCaffery, 1999; Paracloeodes Day, 1955; Patites Thomas \& Dia 2000; Platybaetis Müller-Liebenau, 1980; Plauditus Lugo-Ortiz \& McCafferty, 1998; Prebaetodes Lugo-Ortiz \& McCafferty, 1996; Pseudocloeon Klapalek, 1905; Procloeon Bengtsson, 1915; Prosopistoma Latreille, 1833; Pseudocentroptiloides Jacob (in Jacob \& Glazaczow), 1987; Pseudocentroptilum Bogoescu, 1947; Pseudopannota Waltz \& McCafferty, 1987; Rallidens Penniket, 1966; Raptobaetopus Müller-Liebenau, 1978; Rhithrocloeon Gillies, 1985 Rhodobaetis Jacob, 2003; Securiops Jacobus, McCafferty \& Gattolliat, 2006; Similicloeon Kluge \& Novikova, 1992; Siphlaenigma Penniket, 1962; Siphlonurus Eaton, 1868; Takobia Novikova \& Kluge, 1987; Tanzaniops McCafferty \& Barber-James, 2005; Tenuibaetis Kang \& Yang (in Kang, Chang \& Yang), 1994; Waltzoyphius McCafferty \& Lugo-Ortiz (in Lugo-Ortiz \& McCafferty), 1995; Zelusia Lugo-Ortiz \& McCafferty, 1998.

According to the rank-free classification suggested in "The phylogenetic system of Ephemeroptera" [Kluge, 2004], mayflies discussed here, belong to the taxon Anteropatellata. Their systematic position is the following:

B.1. EPHEMEROPTERA s.str., or EUPLECTOPTERA

B.1.1. ANTERITORNA

B.1.1.1. Plesiomorphon TridentisetA, or Baetis/fg1

B.1.1.1.1. TETRAMEROTARSATA, or Baetis/fg2

B.1.1.1.1.1. LiBEREVENATA, or Baetis/fg3

B.1.1.1.1.1.1. TuRBANOCULATA, or Baetis/fg4

B.1.1.1.1.1.1.1. Anteropatellata, or Baetis/fg5

B.1.1.1.1.1.1.1.1. BAETOVECTATA taxon n., or Baetis/fg6

B.1.1.1.1.1.1.1.1.1. Baetungulata taxon n., or Baetis/fg7

B.1.1.1.1.1.1.1.1.1.1. BAETOFEMORATA taxon n., or Baetis/fg8

B.1.1.1.1.1.1.1.1.1.1.1. BAETOSTERnATA taxon n., or Baetis/fg9

\section{B.1. Euplectoptera, or Ephemeroptera s.str.}

Monosemantic circumscriptional name: Euplectoptera Tillyard,1932.

Non-monosemantic circumscriptional name: EPHEMEROPTERA Hyatt \& Arms, 1890, s.str.

Hierarchical typified name: Ephemera/fg3 (sine Phtharthus; incl. Prosopistoma).

To the general characteristic of Ephemeroptera given in "The phylogenetic system of Ephemeroptera" [Kluge, 2004], the following details should be added:

Cuticular texture of subimaginal tarsi. Besides microtrichia (which are small, setae-like cuticular outgrowths, each produced by a single hypodermal cell), insect cuticle can bear wide and flat outgrowths, which, by analogy with "microtrichia" can be termed "microlepides". Microlepides (singular microlepis, from Greek $\mu 1 \kappa \rho \circ \varsigma$ and $\lambda \varepsilon \pi \mathrm{t} \varsigma, \lambda \varepsilon \pi \mathrm{i} \delta \mathrm{o} \varsigma$ ) are small (as small as microtrichia), wide, semicircular or triangular outgrowths of cuticle, immovably attached to the cuticular surface by their wide sides and situated regularly, resembling fish scales. Probably, microlepides represent a modification of net-like relief, which is found on certain areas of cuticle.

In mayfly subimago, most part of cuticle is covered by microtrichia and other small cuticular outgrowths. Subimaginal thorax and abdomen have taxon-specific areas covered by microtrichiae, areas with net-like relief, and smooth areas. Subimaginal wings are always entirely covered by microtrichia only, while imaginal wings are always smooth. Subimaginal legs often have femur and tibia covered by microtrichia directed distally; tarsus often lacks microtrichia, being covered by microlepides directed distally. Imaginal leg has no such sharp difference between texture of tarsus and tibia; its distal part can be covered by microlepides, which are less prominent than in subimago. Microlepides which cover subim- aginal tarsi, can be either blunt (i.e. with outer margins semicircular or transverse), or sharply pointed. Presence of microtrichiae, pointed microlepides or blunt microlepides on these or that tarsomeres is characteristic for certain mayfly taxa [e.g., see below, Baetungulata (4) and Baetofemorata (2)].

Composition. The taxon Euplectoptera is divided into Posteritorna and Anteritorna (see below).

\section{B.1.1. Anteritorna}

Circumscriptional name: ANTERITORNA Kluge, 1993.

Hierarchical typified name: Ephemera/fg4 (sine Prosopistoma; incl. Baetis et al.).

REFERENCES: Anteritorna: Kluge, 2004.

Diagnosis of this taxon is given in "The phylogenetic system of Ephemeroptera" [Kluge, 2004]. The taxon Anteritorna is divided into a holophyletic taxon Bidentiseta and a plesiomorphon Tridentiseta (see below).

\section{B.1.1.1. Plesiomorphon Tridentiseta, or Baetis/fg1}

Circumscriptional name: Tridentiseta Kluge, Studemann, Landolt \& Gonser, 1995.

Hierarchical typified name: Baetis/fg1 (incl. Siphlonurus et al.) [f: Baetida Leach, 1815: 137; g: Baetis Leach, 1815: 137, typus Ephemera fuscata Linnaeus, 1761 [design ICZN Opinion 787, 1966]. REFERENCES: Tridentiseta: Kluge, 2004.

Tridentiseta is a plesiomorphon consisting of Tetramerotarsata (or Baetis/fg2) (see below), Siphlonurus/fg1, Dipteromimus/fg1, Ameletus/fg1, Metretopus/fg1, Acanthametropus/fg1, Ametropus/fg1, Nesameletus/f1=Metamonius/g1, Vetulata (or Oniscigaster/fg1), Ameletopsis/fg1 and Rallidens/fg1 [Kluge, 2004].

\section{B.1.1.1.1. Tetramerotarsata, or Baetis/fg2}

Circumscriptional name: Tetramerotarsata Kluge, 1997a.

Hierarchical typified name: Baetis/fg2 (sine Siphlonurus et al.; incl. Siphlaenigma).

Possible ranking names in non-phylogenetic classifications:

- superfamily Baetoidea;

- family Baetidae s.1.

REFERENCES: Tetramerotarsata: Kluge, 1997a; 2004.

Autapomorphies. This holophyletic taxon is characterized by a number of autapomorphies, arranged in 13 points in "The phylogenetic system of Ephemeroptera" [Kluge, 2004]. The $1^{\text {st }}$ of them is a peculiar tarsal segmentation, which needs the following closer definition:

(1) Segmentation of adult tarsi (Figs 4-5). Tarsi of middle and hind legs of imago and subimago are 4-segmented, the $1^{\text {st }}$ segment is immovably fused with tibia (while most other mayflies have 5-segnented tarsi, whose $1^{\text {st }}$ segment is fused with tibia). Formerly we had no idea, how four tarsomeres of Tetramerotarsata correspond to the initial five tarsomeres [Kluge, 1997a; 2004]. Actually, in Tetramerotarsata the initial $1^{\text {st }}$ and $2^{\text {nd }}$ tarsomeres are completely fused together, without any traces of the boundary between them. This can be revealed from the following fact: Certain tarsomeres are ventrally-apically produced into an apical spine, which represents a pointed, immovable, sclerotized, cuticular projection; each tarsomere can bear only one apical spine; number of such spine-bearing tarsomeres is taxon-specific, being identical in imago and subimago and identical on middle and hind legs of both sexes; in some species of Liberevenata fore tarsus of female (which always has 5 tarsomeres) has the same number of spine-bearing tarsomeres as middle and hind tarsi (which always have 4 tarsomeres); in all these cases position of the spine-bearing tarsomeres indicates that the $1^{\text {st }}$ tarsomere of the 4-segmented middle and hind tarsi corresponds to the $1^{\text {st }}$ and $2^{\text {nd }}$ tarsomeres of the 5- 
segmented fore tarsus. In order to indicate serial homology between tarsomeres of different pairs of legs, tarsomeres of the 4-segmented middle and hind tarsus should be termed not

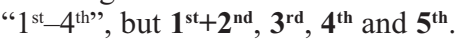

Fore tarsus of male never has apical spines. On other legs, maximum number of apical spines is 3 ; in this case, on 5 -segmented fore leg of female $2^{\text {nd }}, 3^{\text {rd }}$ and $4^{\text {th }}$ tarsomeres are spine-bearing (Fig. 4), and on 4-segmentede middle and hind legs of both sexes $1^{\text {st }}+2^{\text {nd }}, 3^{\text {rd }}$ and $4^{\text {th }}$ tarsomeres are spine-bearing (Fig. 5). In certain taxa number of apical spines is less than 3; on fore leg of female it can be either the same as on middle and hind legs, or different [see below, Acentrella/fg1 (10), Acentrella/fg2 (4), Jubabaetis/g1 (2) and Platybaetis (3)].

Composition. The taxon Tetramerotarsata is divided into Siphlaenigma/fg(1) (monospecific taxon distributed in New Zealand only) and Liberevenata (distributed everywhere, except for New Zealand) (see below).

\section{B.1.1.1.1.1. LibereVenata, or Baetis/fg3}

Circumscriptional name: LiBerevenATA Kluge, 1997a

Hierarchical typified name: Baetis/fg3 (sine Siphlaenigma; incl. Palaeocloeon)

Possible ranking names in non-phylogenetic classifications:

- family Baetidae;

- subfamily Baetinae.

REFERENCES: Liberevenata: Kluge, 1997a; 2004

Autapomorphies. This holophyletic taxon is characterized by a number of autapomorphies, arranged in 7 points in "The phylogenetic system of Ephemeroptera" [Kluge, 2004]. The $4^{\text {th }}$ and $6^{\text {th }}$ of them are features of genital apparatus. Basing on new investigations of genital structure in various representatives of Turbanoculata, these features can be formulated as one composite modification of male genital apparatus; thus, total number of points should be diminished to 6 :

(4) Male genital apparatus (Figs 1-3). Median part of styliger is strongly reduced, while its lateral parts remain to be well developed; these lateral parts of styliger represent a pair of gonostyli pedestals, or unistyligers (Fig. 3: us): they are completely separated one from another; each of them is thick, cylindrical, bears the gonostylus and contains the gonostylar muscle (Fig. 3: m.gs) - i.e. muscle attached to the gonostylus base and serving for adduction of the gonostylus as a whole. Some authors wrongly take the unistyligers for the first segments of gonostyli; actually, gonostyli of mayflies (and insect styli in general) never have muscles inside. Penis (which initially has a pair of sclerotized penial arms articulated to the posterior angles of $10^{\text {th }}$ abdominal tergum and to the anterior angles of styliger) is reduced and modified in such a manner, that consists of a more or less sclerotized penial bridge (Fig. 2: pb) and a pair of sclerotized gonovectes (singular - gonovectis) (Fig. 2: gv); lateral ends of the penial bridge are articulated with posterior angles of $10^{\text {th }}$ abdominal tergum; each gonovectis arises from the penial bridge near its lateral end and is directed medially, at rest is invaginated into the $9^{\text {th }}$ abdominal segment; a pair of gonovectal muscles (Fig. 3: m.gv) go from gonovectes to lateral parts of $9^{\text {th }}$ abdominal sternum; pair of gonoducts (Fig. 3: gd) terminate on apices of gonovectes.

In the genital apparatus initial for Ephemeroptera, styliger can be turned ventrally as a whole by the single median muscle of $9^{\text {th }}$ abdominal sternum (i.e. styligeral muscle) and thanks to this provides protraction of penis [Kluge 2004: Fig. 11]. Unlike it, in Liberevenata this movement is impossible due to reduction of the median part of styliger, to which styligeral muscle is attached. Becoming useless, the styligeral muscle can be weakened (Fig. 3: m.s) or lost.
Probably, the most primitive genital structure among Liberevenata exists in Afroptilum: the median styligeral muscle is well developed and terminates on a special median styligeral sclerite which locates between unistyligers; unistyligers are movable, with membranous bases; because of this, when the median styligeral muscle contracts, unistyligers, instead of turning ventrally as a whole, are brought together, so they act as additional, proximal segments of gonostyli; this movement does not provide protraction of penis. Gonovectes are movable, so that they can move out of their pockets in caudal direction, passing ventrally of the penial bridge, and protract gonopores.

In selected taxa of Liberevenata genital apparatus is simplified and modified in this or that direction. In most Anteropatellata the median styligeral sclerite is lost, and the unistyligers are immovable, so protraction of the median styligeral muscle does not provide adduction of unistyligers. In some taxa (e.g., Baetosternata, Labiobaetis/g1, Echinobaetis, Afroptiloides) the median styligeral muscle is lost. In some taxa (e.g., Cloeon/g1, Rhithrocloeon/g1) gonovectes are immovably fused by their apices with the penial bridge. In Baetovectata, vice verse, gonovectes are especially movable and strongly arched (Figs 1-3) [see below, Baetovectata (2)]. In some taxa penial bridge is desclerotized and non-expressed.

Details of genital apparatus are known for recent representatives only; extinct Palaeocloeon has external shape of unistyligers the same as recent Turbanoculata.

Some details of genital apparatus are difficult for examination, because last abdominal segments of fresh specimens contain numerous non-translucent white inclusions. Because of them, muscles located in the $9^{\text {th }}$ abdominal segment are invisible on slides in Canadian balsam. These white inclusions can be successfully dissolved in warm water during 2-4 hours. Some species have such kind of abdominal coloration, which disappears after treating by warm water; in this case $9^{\text {th }}$ abdominal sternum with genitals should be detached from the rest of abdomen before treating by warm water.

(5) Gonostylus has one distal segment (instead of two initial segments). Non-unique apomorphy. Among Liberevenata this single distal segment disappears in Rhithrocloeon/ g1 only.

(6) Imaginal and subimaginal paracercus is vestigial, one-segmented. Non-unique apomorphy. Larval paracercus can be either well-developed, or also vestigial [e.g., see below, Acentrella/fg1 (5)].

Composition. The taxon Liberevenata is divided into an extinct plesiomorphon Palaeocloeon/fg(1) and a holophyletic taxon Turbanoculata (see below).

\section{B.1.1.1.1.1. Turbanoculata, or Baetis/fg4}

Circumscriptional name: Turbanoculata Kluge, 1997a.

Hierarchical typified name: Baetis/fg4 (sine Palaeocloeon; incl. Centroptiloides).

Possible ranking names in non-phylogenetic classifications:

— family Baetidae s.str.;

- subfamily Baetinae.

REFERENCES: Turbanoculata: Kluge, 1997a; 2004.

Autapomorphies. This holophyletic taxon differs from Palaeocloeon in adult stages by turban eyes of male and by separated furcasternal protuberances [Kluge, 2004]. Its differential diagnosis for larval stage is unclear, because larvae of Palaeocloeon are unknown.

Composition. The taxon Turbanoculata is divided into a plesiomorphon Protopatellata Kluge \& Novikova, taxon nov. (hierarchical name: Afroptilum/f1=Centroptiloides/g1 [f: Afroptilinae Kluge, 1997a; g: Centroptiloides Lestage, 


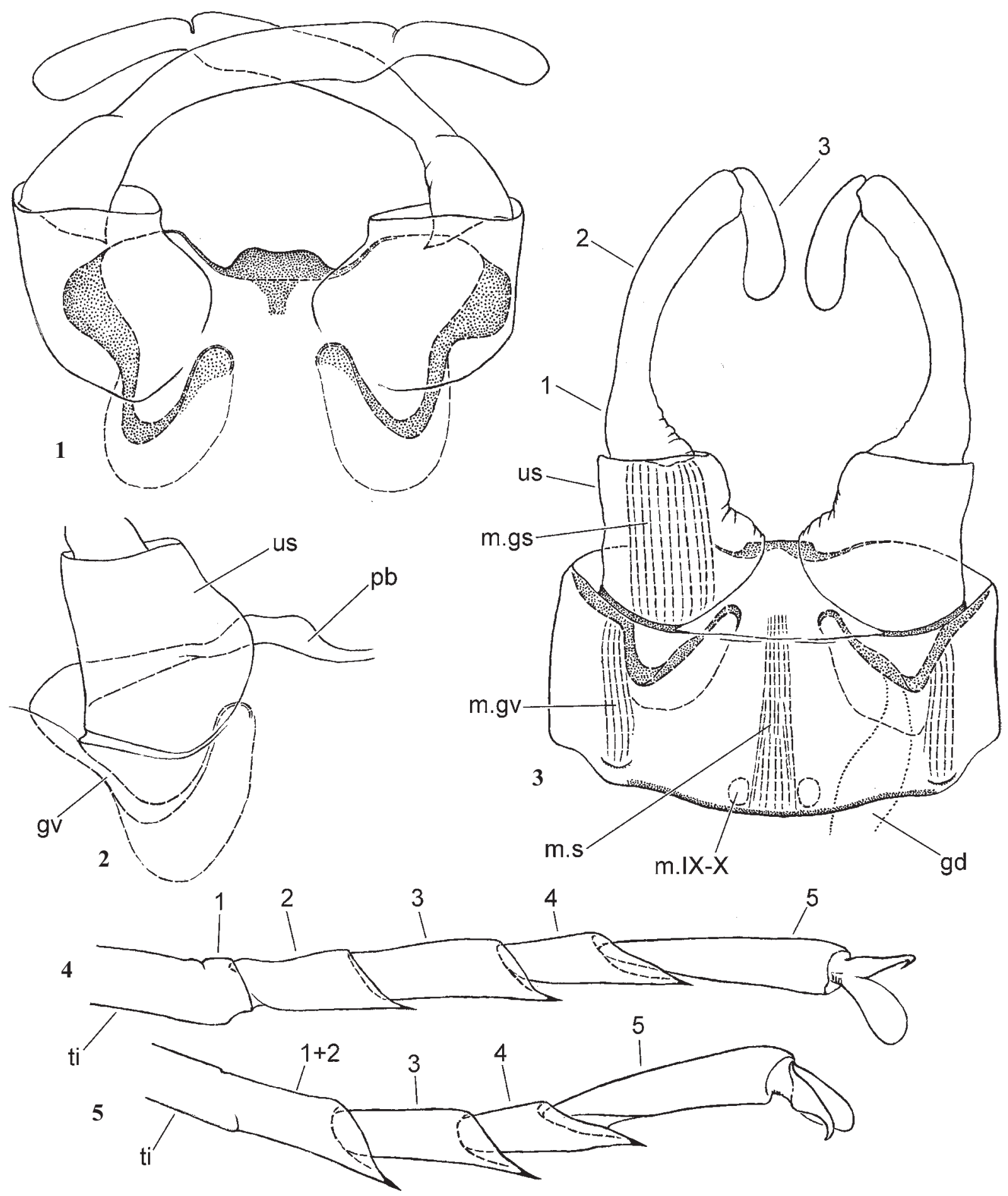

Figs 1-5: Acentrella/fg2 lapponica [Acentrella], imago: 1-3 - genitals of male imago, ventral view (right gonostylar muscle not shown): $\mathbf{1}, \mathbf{2}, \mathbf{3}-1^{\text {st }}, 2^{\text {nd }}$ and $3^{\text {rd }}$ segments of gonostylus; $\mathbf{g d}$ - gonoduct; $\mathbf{g v}$ - gonovectis; $\mathbf{m}$.IX-X — areas of anterior attachment of paired intersegmental ventral muscles going from base of $9^{\text {th }}$ segment to base of $10^{\text {th }}$ segment of abdomen; $\mathbf{m}$.gs - gonostylar muscle, located in unistyliger; $\mathbf{m . g v}$ - muscle-retractor of gonovectis; $\mathbf{m . s}$ - median sterno-styligeral muscle; $\mathbf{p b}$ - penial bridge; us - unistyliger; $4-5-$ tarsi of fore and middle legs of female imago: $1, \mathbf{2}, \mathbf{3}, \mathbf{4}, \mathbf{5}-1^{\text {st }}, 2^{\text {nd }}, 3^{\text {rd }}, 4^{\text {th }}$ and $5^{\text {th }}$ tarsomeres; $1+2$ - completely fused $1^{\text {st }}$ and $2^{\text {nd }}$ tarsomeres.

Pис. 1-5: Acentrella/fg2 lapponica [Acentrella], имаго: 1-3 - гениталии самца имаго, вентрально (правая гоностилярная мышца

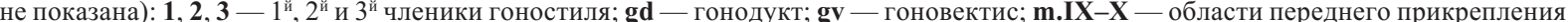
парной межсегментарной мышцы, идущей от основания IX сегмента к основанию X сегмента брюшка; $\mathbf{m} . \mathbf{g s}$ - гоносилярная мышца, расположенная в унистилигере; $\mathbf{m . g v}$ - мышца-ретрактор гоновектиса; $\mathbf{m} . \mathbf{s}$ - медиальная стерно-стилигеральная мышца; $\mathbf{p b}-$ мост пениса; us - унистилигер; 4-5 - лапки передней и средней ног самки имаго: $\mathbf{1 , 2}, \mathbf{3}, \mathbf{4}, \mathbf{5}-1^{\text {й }}, 2^{\text {й }}, 3^{\text {й }}, 4^{\text {й }} 5^{\text {й тарсомеры; }} \mathbf{1 + 2}$

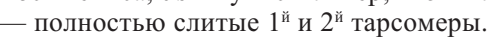


1918]) (distributed mainly in tropical Africa) and the holophyletic taxon Anteropatellata (distributed everywhere, except for New Zealand) (see below).

\section{B.1.1.1.1.1.1. Anteropatellata, or Baetis/fg5}

Circumscriptional name: AnTEROPATEllata Kluge, 1997a.

Hierarchical typified name: Baetis/fg5 (sine Centroptiloides; incl. Cloeon).

Possible ranking name in non-phylogenetic classifications:

- subfamily Baetinae;

- tribe Baetini.

REFERENCES: Anteropatellata: Kluge, 1997a; 2004.

Autapomorphy. This holophyletic taxon is characterized by secondary restoration of patella-tibial suture on fore legs [Kluge, 1997a; 2004]; this character needs to be defined as the following:

(1) Presence of patella-tibial suture on fore leg (Table 1). On fore legs patella-tibial suture is absent only in male imago and subimago, but present in female imago and subimago and in larvae of both sexes (Fig. 18). On middle and hind legs this suture is present in all stages and sexes (except for a few taxa whose patella-tibial suture is modified or lost on all legs).

Table 1. Presence of patella-tibial suture in Anteropatellata. Таблица 1. Наличие пателло-тибиального шва y Anteropatellata

\begin{tabular}{|l|c|c|c|c|c|c|}
\hline \multirow{3}{*}{ stage } & \multicolumn{3}{|c|}{ male } & \multicolumn{3}{c|}{ female } \\
\cline { 2 - 8 } & $\begin{array}{c}\text { fore } \\
\text { leg }\end{array}$ & $\begin{array}{c}\text { middle } \\
\text { leg }\end{array}$ & $\begin{array}{c}\text { hind } \\
\text { leg }\end{array}$ & $\begin{array}{c}\text { fore } \\
\text { leg }\end{array}$ & $\begin{array}{c}\text { middle } \\
\text { leg }\end{array}$ & $\begin{array}{c}\text { hind } \\
\text { leg }\end{array}$ \\
\hline larva & + & + & + & + & + & + \\
\hline subimago & - & + & + & + & + & + \\
\hline imago & - & + & + & + & + & + \\
\hline
\end{tabular}

Unlike Anteropatellata, plesiomorphons Siphlaenigma, Palaeocloeon and Protopatellata have the same position of patella-tibial suture, as in most Ephemeroptera: their patellatibial suture is retained on middle and hind legs only, being lost on fore legs of all stages and both sexes.

Composition. Complete composition of Anteropatellata is unclear; among the taxa examined, here belong the following ones: Baetovectata (see below); Cloeon/fg1 (incl. Procloeon, Pseudocentroptilum, Similicloeon, Intercloeon, Pseudocentroptiloides, Securiops); Centroptilum/g(1); Baetopus/g1 (incl. Raptobaetopus); Cheleocloeon/g(1); Afrobaetodes/g(1).

\section{B.1.1.1.1.1.1.1. BaEtovectata taxon nov., or Baetis/fg6}

Circumscriptional name: BaEtovectata Kluge \& Novikova, taxon nov.

Hierarchical typified name: Baetis/fg6 (sine Cloeon et al.; incl. Callibaetis et al.).

Possible ranking names in non-phylogenetic classifications:

- subfamily Baetinae;

- tribe Baetini.

This taxon is recognizable by presence of double intercalaries on wings, that is a well-known character. Basing on this character, most Baetovectata had been placed to the subfamily Baetinae sensu Kazlauskas, 1972, which was opposed to the subfamily Cloeoninae; but Callibaetis has so striking difference from other Baetovectata in larval structure, that it was placed either to a separate subfamily Callibaetinae Riek, 1973, or to the subfamily Cloeoninae sensu Landa \& Soldan, 1985. Here we establish for all baetids with double intercalaries a new taxon Baetovectata, whose holophyly is supported by unique genital structure, nearly uniform in all representatives.

\section{Autapomorphies.}

(1) Marginal intercalary veins of fore wing are two in each space (Figs 29, 198). Sometimes in selected fields or even in all fields only one intercalary is present (e.g., in selected representatives of Callibaetis/fg1, Cloeodes/g1). Unlike Baetovectata, other Turbanoculata (i.e., Palaeocloeon, Protopatellata, Cloeon/fg1, Centroptilum, Baetopus/fg1, Cheleocloeon and Afrobaetodes) never have more than one intercalary in each space, that is initial for Liberevenata [Kluge, 1997a; 2004].

(2) Penis has peculiar shape of gonovectes [see Liberevenata (4)]: they are narrow, arched, deeply invaginated into $9^{\text {th }}$ abdominal segment (Figs 1-3, 38, 70, 77, 87, 96, 109, 114, 132, 140, $149,161,162,197)$. In subimago gonovectes are already sclerotized, so that sclerotized gonovectes are distinguishable on subimaginal exuviae (unlike other mayflies, whose subimaginal cuticle has no sclerotized internal penial arms). Exception is made by chantauensis [Baetis], whose gonovectes are thick and only slightly arched (Figs. 57, 60, 61).

(3) In mature larva ready to molt to subimago, buds of subimaginal gonostyli are folded under larval cuticle in such a manner, that $2^{\text {nd }}$ segment of gonostylus as a whole is directed caudally or medially, but not laterally (unlike other Turbanoculata). Probably the primitive condition for Baetovectata is the "Nigrobaetis-type", when the $2^{\text {nd }}$ segment as a whole is directed caudally; in this case the $2^{\text {nd }}$ segment can be either dipped into the $1^{\text {st }}$ segment, or can be curved by its convexity medially, so that its proximal part is directed medially and apex laterally. Derived are the "Baetis-type", "Labiobaetis-type" and "Acentrella-type" [see below, Acentrella/fg1 (9)], when the $2^{\text {nd }}$ and $3^{\text {rd }}$ segments are directed medially [Kluge, 2004].

Composition. Complete composition of Baetovectata is unclear; among the taxa examined, here belong the following ones: Baetungulata (see below); Callibaetis/fg1; Cloeodes/g1 (incl. Centroptella, Chopralla, Bungona); Paracloeodes/g(1); Waltzoyphius/g(1); Aturbina/g(1).

\section{B.1.1.1.1.1.1.1.1.1. Baetungulata taxon nov., or Baetis/fg7}

Circumscriptional name: Baetungulata Kluge \& Novikova, taxon nov.

Hierarchical typified name: Baetis/fg7 (sine Callibaetis et al.; incl. Nigrobaetis et al.).

Possible ranking names in non-phylogenetic classifications:

— subfamily Baetinae;

- tribe Baetini;

- genus Baetis.

This taxon approximately corresponds to the subfamily Baetinae sensu Kazlauskas, 1972 and includes most baetids whose larvae have Baetis-like and Acentrella-like appearance, being adopted to inhabitance in running waters. Most representatives (and among them all European ones) were traditionally placed to the genera Baetis and Pseudocloeon, among which Baetis in such sense was a plesiomorphon, and Pseudocloeon was a polyphyletic taxon. To make the classification more natural, we included Pseudocloeon into Baetis and divided this large genus Baetis s.l. into several subgenera - Baetis s.str., Nigrobaetis, Takobia, Labiobaetis, Acentrella, Baetiella and others [Novikova \& Kluge, 1987]. At the same year Waltz $\&$ McCafferty [1987a-b] attributed to these taxa generic ranks. Recently some authors regard these taxa as separate genera, while others include them in the genus Baetis s.l. [Jacob, 2003]. Here we establish for this group a newly circumscribed taxon Baetungulata, whose holophyly is supported by several apomorphies, each of which is, however, non-unique. 

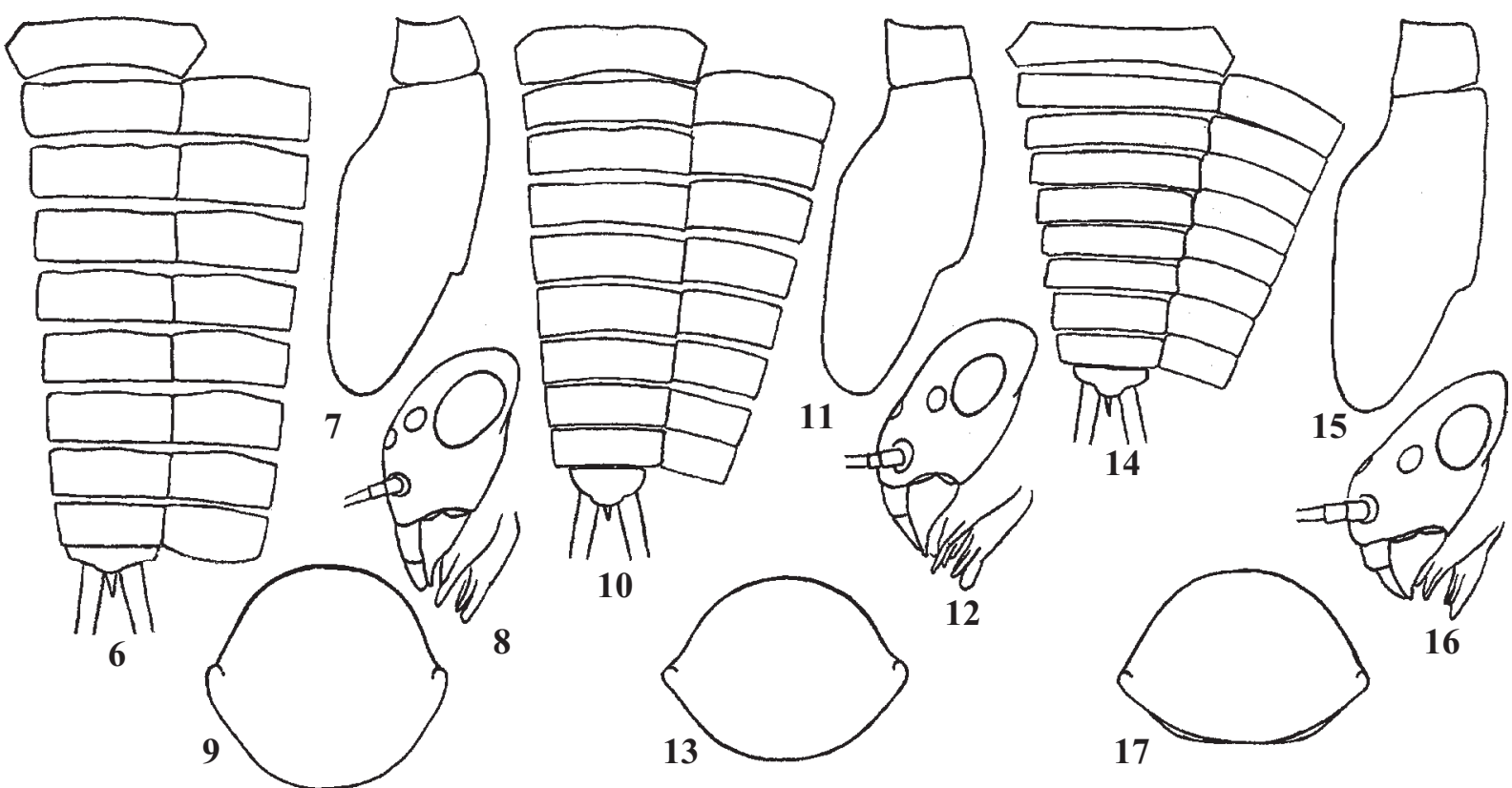

Figs 6-17: Comparison of larval proportions. 6-9-Rhodobaetis/g1 bicaudatus [Baetis] (as example of two-tailed larva with typical Baetis-like appearance); 10-13 - Acentrella/g2 fenestratum [Pseudocloeon]; 14-17 - Acentrella/g2 sibiricum [Pseudocloeon]. 6, 10, 14 - exuviae of abdominal terga spread on slide; 7, 11, 15 - exuviae of left half of pro- and mesonotum, at the same scale; $8,12,16$ - head, lateral view; 9, 13,17 - transverse section at hind margin of abdominal segment III.

Рис. 6-17: Сравнение личиночных пропорций. 6-9-Rhodobaetis/g1 bicaudatus [Baetis] (как пример двухвостой личинки типично Baetis-подобного облика); 10-13 - Acentrella/g2 fenestratum [Pseudocloeon]; 14-17 — Acentrella/g2 sibiricum [Pseudocloeon]. 6, 10, 14 - экзувии тергитов брюшка, расправленные на препарате; 7, 11, 15 - экзувии левой половины про- и мезонотума, в том же масштабе; 8, 12, 16 - голова, латерально; 9, 13, 17 - поперечное сечение заднего края III сегмента брюшка.

\section{Autapomorphies.}

(1) In larva, on inner side of claw instead of two equal rows of denticles [see Tetramerotarsata (11) in "The phylogenetic system of Ephemeroptera"] [Kluge, 2004] only one, inner-anterior row is developed (Fig. 32, 47). This row of denticles is nearly always present, except for a single species Takobia/g1 maxillare [Centroptilum], whose denticles are lost. Nearly always, the second (inner-posterior) row of denticles is completely absent; if it is present (in Heterocloeon/ g1, Andesiops/g1), its denticles are much shorter than denticles of the inner-anterior row. Besides Baetungulata, a similar single inner-anterior row of denticles is found in some mayfly groups where two rows are never present - in Pentamerotarsata, Ephemerella/fg1, Leptophlebia/fg1.

(2) Tergalii have lost ability to make rhythmical respiratory movements (while, as in all mayflies, tergalial muscles are retained, and tergalii are able to change pose). Nonunique apomorphy.

(3) Maxillary palp is 2-segmented (the same in many other taxa). In Guajirolus/fg1 (incl. Chane) and Pseudopannota/g2 (sine Ophelmatostoma; incl. Hemipannota) first segment of maxillary palp is divided into two parts, so palp superficially looks as 3-segmented.

(4) At least on fore leg of male subimago tarsal segments 1-4 are covered mainly by blunt microlepides (see B.1). Thus, texture of subimaginal legs is the following: Femora and tibiae ere covered by microtrichiae (as in most other Ephemeroptera). On fore tarsus of male segments 1-4 are covered mainly by blunt microlepides; only in distal part of each segment pointed microlepides can be present (unlike some other Tetramerotarsata, whose fore tarsus of male is entirely covered by pointed microlepides). Distal segment of fore tarsus of male and tarsi of other legs are covered either by pointed, or by blunt microlepides [see below, Baetofemorata (2)].

Composition. Complete composition of Baetungulata is unclear; among the taxa examined, here belong the following ones: Baetofemorata (see below); Nigrobaetis/g1 (incl. Diphetor, Takobia, Alainites); Labiobaetis/g1 (incl. Pseudopannota, Hemipannota, Ophelmatostoma); Echinobaetis/g(1); Acerpenna/g(1); Camelobaetidius/g1 (incl. Dactylobaetis); Baetodes/ g1 (incl. Prebaetodes); Fallceon/g(1); Caribaetis/g(1); Americabaetis/g(1); Mayobaetis/g(1); Edmundsiops/g(1); Andesiops/g1 (incl. Deceptiviosa); Nanomis/g(1); Zelusia/g(1); Offadens/g(1); Guajirolus/g1 (incl. Chane).

\section{B.1.1.1.1.1.1.1.1.1.1. BaEtofemorata taxon nov., or Baetis/fg8}

Circumscriptional name: BAEtofemorata Kluge \& Novikova, taxon nov.

Hierarchical typified name: Baetis/fg8 (sine Nigrobaetis et al.; incl. Acentrella et al.).

Possible ranking names in non-phylogenetic classifications:

— subfamily Baetinae:

- tribe Baetini;

- genus Baetis.

This taxon has been circumscribed and characterized by Waltz \& McCafferty [1987a-b], who described femoral patch and revealed its phylogenetic significance. However, the holophyletic group characterized by presence of the femoral patch (villopore) has no taxonomic status. Here we establish for it a new taxon Baetofemorata.

\section{Autapomorphies.}

(1) In larva, each femur in its proximal part of inner side bears villopore - a patch of small $(0.02 \mathrm{~mm}$ long) bristles closely pressed together [Waltz \& McCafferty, 1987a-b]. 
Besides Baetofemorata, similar bristles occur in some species of Labiobaetis/g1, being less closely accumulated.

(2) On all legs of subimago each tarsal segment is covered mainly by blunt microlepides; only in distal part of each segment pointed microlepides can be present [as on segments 1-4 of male fore tarsus - see Baetungulata (4)]. The same in some other taxa.

Composition. Complete composition of Baetofemorata is unclear; among the taxa examined, here belong the following ones: Baetosternata (see below), Acentrella/fg1 (see below), Patites/g(1) and some other taxa.

\section{B.1.1.1.1.1.1.1.1.1.1. BAETOSTERnata taxon nov., or Baetis/fg9}

Circumscriptional name: BaEtosternata Kluge \& Novikova, taxon nov.

Hierarchical typified name: Baetis/fg9 (sine Acentrella et al.; incl. Baetiella et al.)

Possible ranking names in non-phylogenetic classifications:

- tribe Baetini;

— genus Baetis;

- subgenus Baetis in genus Baetis.

This taxon is established basing on a newly discovered character in genital structure.

Autapomorphy.

(1) Median styligeral muscle [non-functional-see Liberevenata (4)] is completely lost. This is a non-unique apomorphy: besides Baetosternata, this muscle is lost in some Baetungulata-non-Baetofemorata (e.g., Labiobaetis/g1 and Echinobaetis) and in some Protopatellata (e.g., Afroptiloides).

Composition. The taxon Baetosternata, besides Baetis s.str., includes taxa known as genera and subgenera Baetiella, Rhodobaetis, Glossidion, Tenuibaetis.

\section{Systematics of Acentrella/fg1}

In the present paper we use the following classification of examined taxa:

C.1. Acentrella/fg1

C.1.1. Plesiomorphon Acentrella/fg2

C.1.1.1. Plesiomorphon: group lapponica

C.1.1.1-1. Acentrella/fg2 lapponica [Acentrella]

C.1.1.1-2. Acentrella/fg2 feropagus [Acentrella]

C.1.1.1-3. Acentrella/fg2 sinaica [Acentrella]

C.1.1.1-4. Acentrella/fg2 charadra $[$ Acentrella]

C.1.1.1-5. Acentrella/fg2 chantauensis [Baetis]

C.1.1.1-6. Acentrella/fg2 joosti [Baetis]

C.1.1.2. Group fenestratum

C.1.1.2-1. Acentrella/fg2 fenestratum [Pseudocloeon]

C.1.1.3. Group inexpectatum

C.1.1.3-1. Acentrella/fg2 inexpectatum [Pseudocloeon]

C.1.1.3-2. Acentrella/fg2 gnom [Pseudocloeon]

C.1.1.4. Group sibiricum

C.1.1.4-1. Acentrella/fg2 sibiricum [Pseudocloeon]

C.1.1.4-2. Acentrella/fg2 diptera sp.n. [Acentrella]

C.1.1.4-3. Acentrella/fg2 scabriventris sp.n. [Acentrella]

C.1.1.5. Uncertain group: Acentrella/fg2 sp.

C.1.2. Jubabaetis/g1

C.1.2.1. Tanzaniops/g(1), or Tanzaniops

C.1.2.1-1. Tanzaniops/g(1) lunamontana sp.n. [Acentrella (Tanzaniops)

C.1.2.1-2. Tanzaniops/g(1) spinosa [Tanzaniella]

C.1.2.2. Jubabaetis/g2

C.1.2.2.1. Plesiomorphon Liebebiella/g(1), or Liebebiella

C.1.2.2.1-1. Liebebiella/g(1) verum [Pseudocloeon]

C.1.2.2.1-2. Liebebiella/g(1) bispinosa sp.n. [Acentrella (Liebebiella)]
C.1.2.2.1-3. Liebebiella/g(1) cylindroculata sp.n. [Acentrella (Liebebiella)]

C.1.2.2.1-4. Liebebiella/g(1) proximum [Pseudocloeon]

C.1.2.2.1-5. Liebebiella/g(1) sp.

C.1.2.2.2. Jubabaetis/g3

C.1.2.2.2-1. Jubabaetis/g3 sp.

C.1.2.2.3. Platybaetis/g(1), or Platybaetis

C.1.2.2.3-1. Platybaetis/g(1) mamasae sp.n. [Platybaetis]

C.1.2.2.3-2. Platybaetis/g(1) wallacei [Platybaetis]

C.1.2.2.3-3. Platybaetis/g(1) probus [Platybaetis]

C.1.2.2.3-4. Platybaetis/g(1) sp.

\section{C.1. Acentrella/fg1}

(Figs 1-5, 10-206)

Systematic position: Baetofemorata-Acentrella/fg1.

Hierarchical typified name: Acentrella/fg1 (incl. Jubabaetis) [f: Acentrellini Kluge \& Novikova, tribus n., type genus Acentrella; g: Acentrella Bengtsson, 1912, typus A. lapponica Bengtsson, 1912 (monotypy)].

Possible ranking names in non-phylogenetic classifications:

- tribe Acentrellini;

- genus Acentrella

- subgenus Acentrella in genus Baetis.

This taxon is circumscribed here for the first time; it consists of mayflies formerly attributed to the genera or subgenera Acentrella, Tanzaniops, Liebebiella, Jubabaetis and Platybaetis. Two-winged representatives were also attributed to the artificial genus Pseudocloeon (see A.1).

Autapomorphies and characters of unclear phylogenetic status. The most reliable diagnostic characters of Acentrella/fg1 are presence a regular setal row on larval tibia [see (3)] and shape of anteronotal protuberance of adults [see (6)], while the both characters are not unique.

LARVAL CHARACTERS:

(1) Labial palp has $2^{\text {nd }}$ segment without large inner-apical projection, $3^{\text {rd }}$ segment widened and rounded. Muscle in $2^{\text {nd }}$ segment can be either retained (Fig. 39, 128, 152), or lost (Fig. 101).

(2) Larva is adapted for inhabitance on stones in rapid current; it lost the primary siphlonuroid swimming specialization (which is retained in most other Baetofemorata) and has general appearance of "Acentrella-type" (Figs 10-17, 18): body is short, with ventral side flattened; thorax is enlarged, with leg bases widely separated; abdomen is diminished. Head, retaining plesiomorphic hypognathous position (as in other Tetramerotarsata), at the same time is depressed dorso-ventrally, so mouthparts are shortened, and frons is somewhat projected above clypeus (Figs 12, 16, 123-124). Legs are widely separated, long; femur has a row of long dense setae along outer margin; tibia has a similar setal row [see (3)]; tarsi are twisted so that claws are directed perpendicular to the general leg flatness. Each abdominal tergum is shortened thanks to reduction of its anterior part, so that medioanterior sigilla are adjacent to anterior margin of tergum and do not form separate maculae (Figs 110,134) (on sterna medioanterior sigilla retain form of oblique stripes separated from anterior margin — Figs 23, 99, 113). Cerci are long, their primary swimming setae are more or less reduced: either diminished (Fig. 94), or vestigial (Figs 156, 166, 167), rarely completely lost (Table 2). Paracercus is reduced [see (5)]. Because of these modifications, larva lost ability for normal swimming: its legs, being widely separated, can not be stretched backward and pressed to the body; its abdomen, being too short, can not make undulate movements; its caudalii, consisting of long and nearly nude cerci, cannot serve as a swimming flipper. In natural condition larva does not swim, but crawls on stone surface. If put it into a glass with stagnant water and smooth walls, larva tries to swim: making 


\begin{tabular}{|c|c|c|c|c|c|c|c|c|c|c|c|c|c|c|c|c|c|c|c|c|c|c|}
\hline กิ & 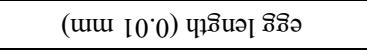 & $\because$ & & 64 & 2 & as & & & 2 & & $\because$ & $\approx 0$ & & 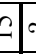 & & & & 의 & r. & c. $a$ & & $\sigma$ \\
\hline$\underset{N}{\infty}$ & 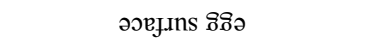 & 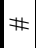 & \# & $\theta=$ & $\#=$ & $\pm \neq$ & & & $\square$ & & 1 & 1 & a. & . & $\therefore a$ & $\sigma$. & $a$ & $\therefore$. & 。. & $a \cdot a$ & . & $a$. \\
\hline$\hat{\imath}$ & 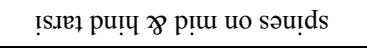 & $m$ & $m$ & $\therefore$ & $m$ & n & c & $m$ & $n$ & & $m$ & $m$ & $m$ & $n$ & $m a$ & $m$ & $m$ & $m$ & $m$ & $\mathrm{~N} \sim$ & a. & a. \\
\hline 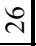 & $\square$ Jo sns.te ə.of uo səu!̣ds & $m$ & $m$ & 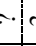 & $m$ & $n$ & c & $m$ & $n$ & & $m$ & $m$ & a. & v & $\mathrm{N} /$ & a & $\mathrm{N}$ & N & $\mathrm{Nat}$ & $\mathrm{N} \sim$ & a. & $\sim$. \\
\hline cิ & 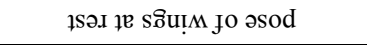 & $=$ & $\sigma$. & $=$ & $=$ & $=a$ & $=$ & $=$ & $==$ & $=$ & $=$ & $=$ & a. & $=$ & $\therefore a$ & $=$ & $=$ & $=$ & a. & 1 & a. & $a$. \\
\hline it & ภิu!̣ pu!̣ & + & + & + & + & + & 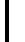 & 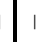 & 11 & । & 1 & 1 & 1 & । & 111 & 1 & 1 & 1 & 1 & 11 & & 1 \\
\hline$i$ & 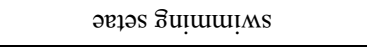 & $1+$ & + & + & + & + & & & ++ & + & + & + & + & (1) & +1 & I+ + & I & I & + & ++ & + & + \\
\hline บ & 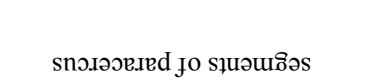 & $\begin{array}{ll}0 \\
1\end{array}$ & . & I & I & 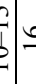 & & & $\begin{array}{lll}0 & 0 \\
i & 1 \\
n & n \\
c\end{array}$ & - & & - & $\infty$ & - & $=-$ & $-\frac{ \pm}{d}$ & - & - & \pm & & & \\
\hline N & 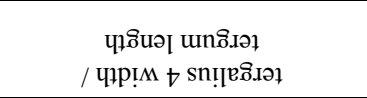 & $\begin{array}{l}7 \\
n \\
0 \\
0\end{array}$ & \begin{tabular}{|l|}
$\infty$ \\
0 \\
0 \\
0 \\
0
\end{tabular} & 1 & & $\overrightarrow{0}$ & $\bar{\alpha}$ & $\left\{\begin{array}{l}\infty \\
n\end{array}\right.$ & $\begin{array}{l}0 \\
i \\
i\end{array}$ & $\stackrel{\sim}{\sim}$ & $\begin{array}{l}-1 \\
0 \\
0 \\
0\end{array}$ & 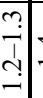 & + & 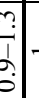 & & I & $\stackrel{?}{I}$ & $\stackrel{\square}{\perp}$ & 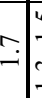 & & & 0 \\
\hline iे & 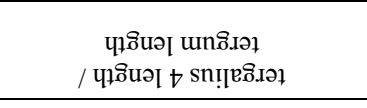 & 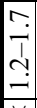 & רִ & & $\begin{array}{c}a \\
\\
\end{array}$ & & & {$\left[\begin{array}{l}\infty \\
1 \\
1 \\
n\end{array}\right.$} & & & \begin{tabular}{|ll}
$N$ \\
$n$ \\
$\sim$
\end{tabular} & $\begin{array}{l}N \\
i \\
\Lambda \\
N\end{array}$ & & . & a & . & $\begin{array}{l}\infty \\
7 \\
-\end{array}$ & 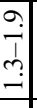 & $\begin{array}{l}+ \\
i \\
i\end{array}$ & & & \\
\hline 2 & 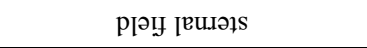 & v & : & $1:$ & \# & $+1+$ & 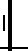 & $\vdots$ & $\begin{array}{l}1 \\
1 \\
\end{array}$ & $\vdots$ & 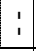 & Z & $i$ & $i$ & is & : & $\begin{array}{l}1 \\
1\end{array}$ & $\vdots$ & $i$ & $i$ & & 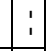 \\
\hline$\infty$ & 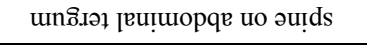 & 1 & 1 & 1 & 1 & 1 & T. & । & 11 & & 1 & । & । & - & 11 & 11 & $\mathrm{~N}$ & 1 & - & 11 & & 1 \\
\hline 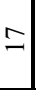 & 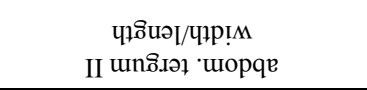 & $f$ & + & f & & 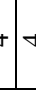 & 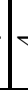 & + & $+\frac{\pi}{f}$ & & $\begin{array}{l}0 \\
1 \\
n\end{array}$ & 6 & n & $\begin{array}{l}n \\
\dot{y} \\
n \\
n \\
n \\
n\end{array}$ & $\begin{array}{l}n \\
\dot{y} \\
\dot{f}\end{array}$ & 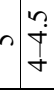 & $\stackrel{n}{+}$ & $n$ & r & & & 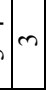 \\
\hline$\div$ & sмe[0 uо әвґәs [вэ!deqns & + & + & 1 & 1 & 1 & 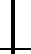 & । & 11 & 1 & 1 & 1 & 1 & + & 111 & 11 & 1 & 1 & 1 & 11 & & 1 \\
\hline$n$ & $\operatorname{sMe}[0$ & $=$ & $\begin{array}{l}m \\
a \\
a\end{array}$ & & & 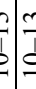 & s & & & & $\frac{0}{1}$ & $\frac{0}{1}$ & $\begin{array}{l}a \\
\infty\end{array}$ & 0 & $\frac{c}{d}=$ & 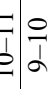 & $\begin{array}{c}0 \\
\infty\end{array}$ & & in & & 0 & $\left\{\begin{array}{lll}\infty \\
1 \\
1\end{array}\right.$ \\
\hline \pm & 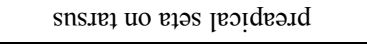 & । & 1 & 1 & 1 & 1 & & । & 11 & & 1 & 1 & 1 & । & ++ & ++ & + & + & + & ++ & & + \\
\hline 2 & мо. [в!q!ฺ pu乙 & 1 & 1 & 1 & 1 & $1 \mid$ & & । 1 & $\begin{array}{ll}1 & 1 \\
\end{array}$ & + & 1 & 1 & + & । & +1 & 1+ & 1 & 1 & 1 & 11 & & 1 \\
\hline$\simeq$ & ЧІр!М вІ৭!ฺ & 1 & $\stackrel{+}{\circ}$ & r & - & 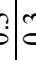 & e & $?$ & $\stackrel{n}{2} \approx$ & & $\because$ & $\because$ & $=$ & $?$ & - & $v \cong$ & $N$ & $N$ & v & & & 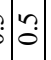 \\
\hline$=1$ & ถิอ & 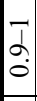 & - & - & - & : & & -1 & $\begin{array}{l}\dot{b} \\
\vdots \\
\dot{b}\end{array}$ & & $\begin{array}{l}2 \\
0 \\
0 \\
0 \\
0\end{array}$ & $\begin{array}{l}0 \\
\vdots \\
0 \\
0 \\
0 \\
0\end{array}$ & $\begin{array}{l}\infty \\
0 \\
0\end{array}$ & - & b. & - & - & - & 一 & $-\left[\begin{array}{c}0 \\
0 \\
\infty \\
0\end{array}\right.$ & & $\mid \begin{array}{l}\infty \\
0 \\
0\end{array}$ \\
\hline 의 & ภิว ว. & - & - & - & - & $c^{\circ}$ & 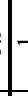 & -10 & 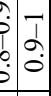 & à & - & - & & . & & 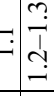 & $\mid \begin{array}{c}m \\
-1 \\
-1\end{array}$ & 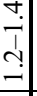 & $\stackrel{v}{-}$ & $-\left(\begin{array}{c}0 \\
0 \\
\infty \\
0\end{array}\right.$ & & 10 \\
\hline$a$ & 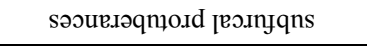 & 1 & 1 & । & 1 & 1 & 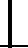 & । & $1+$ & + & + & + & + & + & & 1 & 1 & 1 & 1 & 11 & & 1 \\
\hline$\infty$ & umpouo.d jes.re & $a$ & 2 & 2 & 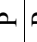 & 4 & e & 12 & $z$ & a & $a$ & 2 & & 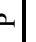 & & a & $z$ & $\mathrm{z}$ & & 2 & & \\
\hline- & qा'd 'ußəəs ${ }_{p u}$ & + & + & + & + & + & + & ++ & ++ & I & 1 & । & 6. & + & $\therefore \cdot a$ & + & + & + & 1 & ++ & & + \\
\hline 6 & 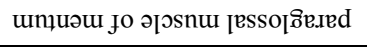 & $=$ & $=$ & - & - & $=$ & - & $=$ & $=$ & 三 & $=$ & 二 & - & 二 & $=$ & $y=$ & $=$ & $=$ & $=$ & $=$ & & $=$ \\
\hline$n$ & ๒ॅош भә & 1 & 1 & 1 & 1 & 1 & & । & $1 \mid$ & । & 1 & । & । & + & ++ & ++ & + & + & + & ++ & & + \\
\hline$\nabla$ & әу!I-регq & 1 & 1 & 1 & 1 & । & & । & $\begin{array}{ll}1 & 1 \\
\end{array}$ & । & 1 & 1 & 1 & + & & 1 & + & + & 1 & ++ & & + \\
\hline$m$ & әвұәs әsuәр чџ!м suo.J & 1 & 1 & 1 & I & । & & 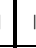 & 11 & 1 & 1 & 1 & I & + & 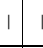 & $1+$ & + & + & + & 11 & & 1 \\
\hline$\sqrt{1}$ & 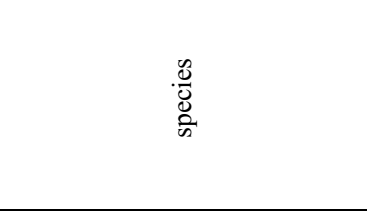 & $\frac{5}{8}$ & $\begin{array}{c}7 \\
\vdots \\
5 \\
5 \\
\vdots \\
\vdots\end{array}$ & & $\Phi$ & 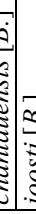 & & 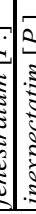 & 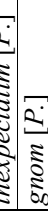 & ב. & 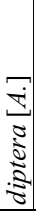 & 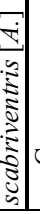 & & 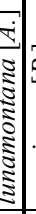 & & 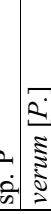 & 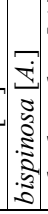 & 이 & $\begin{array}{l}\bar{m} \\
\dot{0} \\
\end{array}$ & 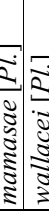 & 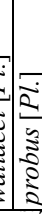 & 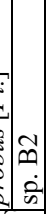 \\
\hline & Oxe? & & & & & & & & Uоч & d.oo & $\mathrm{u}$ & d & & & & $\partial$ & & & & & $p$ & \\
\hline
\end{tabular}


non-effective dorso-ventral movements by abdomen, it swims up, than stops an slowly falls down passively, keeping its legs directed laterally, abdomen bent dorsally and cerci widely diverging.

In various species of Acentrella/fg1 these characters are expressed in various degrees. Degree of ventral flattening and shortening of abdomen can be characterized by ratio between width of $2^{\text {nd }}$ abdominal tergum (distance between tergalii bases) to its length, measured on dissected exuviae spread on slide (Table 2): if larva is flattened ventrally and convex dorsally, its terga, being spread on slide, appear to be much wider than sterna (Figs 10,14). Larvae of Platybaetis lost the "Acentrella-type" habitus and got a unique specialization [see below, Platybaetis (2), (3)].

Besides Acentella/fg1, the same habitus of "Acentrellatype" independently appeared in some other, non-related taxa - e.g., Baetiella (belonging to Baetosternata), Baetodes and Deceptiviosa (belonging to Baetungulata-non-Baetofemorata), Afroptiloides (belonging to Protopatellata). So this character, being an autapomorphy of Acentrella/fg1, is not enough to prove its holophyly.

(3) Larval tibia on outer-dorsal side bears a regular longitudinal row of setae; these setae can be long (Fig. 104, 138) or short (Fig. 67). This regular setal row on outer-dorsal side of tibia resembles the regular setal row on outer-dorsal side of femur, which occurs, besides Acentrella/fg1, in many other Baetofemorata. In Acentrella/fg1 setae of these femoral and tibial rows are often feathered, i.e. bear on their sides numerous very fine processes; in some species these processes are longer than half of distance between neighboring setae (Fig. 189), so that setae touch one another by these processes and thanks to this stay parallel one to another; in other species these processes are much shorter or absent. Presence of long setae is connected with general rheophilous adaptation [see (2)]; peculiarity of Acentrella/fg1 is that the tibial row of setae is always regular (unlike Baetiella and some others, whose tibiae bear irregularly situated long setae on the same place).

Besides Acentrella/fg1, the same regular tibial setal row is found in some non-related taxa - e.g., Baetodes/g2 (sine Prebaetodes), Deceptivosa, Echinobaetis (belonging to Baetungulata-non-Baetofemorata), Afroptiloides and Micksiops (belonging to Protopatellata),

Some species of Acentrella/fg1, besides the regular row of setae along outer-dorsal side of tibia, have an additional regular row of setae along outer side of tibia; on hind legs setae of this additional row can be long, on middle and fore legs its setae can be shorter and poorly visible. Such addition-

Table legend. 1 - supra-species taxon: T. — Tanzaniops; J. — Jubabaetis/g3; 2 - species (primary generic names: A. — Acentrella; B. - Baetis; P. - Pseudocloeon; Pl. - Platybaetis); 3-29 - characters: 3 - "+" frons with dense setae (Fig. 124); “-" frons without dense setae; 4 - "+" mandibles blad-like (Figs 136, 137, 154, 155, 168, 169, 193, 194, 202, 203); "-" mandibles not blad-like (Figs 102, 141, 142); 5 - "+" left mola with very small petiolate projections (Figs 136, 154, 168193, 202); "-" left mola with usual large projections (Fig. 102); 6 (paraglossal muscles of mentum) - "`" oblique (Figs 39, 101,152); “|"” parallel to glossal muscles (Fig. 128); 7 (muscle of second segment of labial palp) — "+" present (Figs 39, 128, 152); “-” absent (Fig. 101); 8 (larval pronotum) — "P” sigilla, if expressed, positive, i.e. dark on lighter background (Fig.133 ); "N" sigilla, if expressed, negative, i.e. light on darker background; 9 (subfurcal protuberances on larval meso- and metathorax _ _ "+" prominent; "_" small or absent; 10-11 — ratio of tibia length to femur length in larva; $\mathbf{1 2}$ - ratio of tibial setae length to tibia width in larva; 13 (second row of setae on larval hind tibia) - " "” present (Fig. 89); "-" absent (Fig. 104 ); 14 (long preapical seta on larval tarsus) - " " " present (Fig. 192); “-” absent (Fig. 48); 15 - number of denticles on larval claw; 16 (subapical setae on larval claw) - " "+ two well developed setae near tip (Fig. 32); "-" setae vestigial or not reaching tip (Fig. 47); 17 - ratio of width of spread abdominal tergum II between tergalii bases to its length; 18 - number of dorsal spines or protuberances on each or some abdominal terga of larva; 19 (shape of fields of dentate protuberances on abdominal sterna of larva) _ " . ." small and transverse (Fig. 99); "V/" larger and oblique (Fig. 113); ">> " larger, oblique and connected with fields on hind margin of sternum (Fig. 23); "\#\#" contiguous medially and covering most part of sternum; “-” fields of dentate protuberances are small and transverse, but rest of sternum is covered by non-dentate protuberances (Fig. 59); 20-21 - ratio of middle tergalius to tergum length; $\mathbf{2 2}$ - number of segment of larval paracercus; $\mathbf{2 3}$ (swimming setae on inner side of larval cerci) - " "+" present (Fig. 94); "-" completely absent; "(-)" absent, but vestiges of their bases are retained (Figs 156, 166, 167); 24 (hind wing) _ “+” present (Figs 29-31); “-” absent; 25 (pose of imaginal and subimaginal wings at rest) - " "||" raised up; “- -" spread laterally (Fig. 201); 26 - number of spine-bearing segments on fore tarsus of female imago and subimago; 27 — number of spine-bearing segments on middle and hind tarsi of imago and subimago; 28 (egg surface) - "\#” with reticulate relief (Figs 118-119); "”” with longitudinal ridges (Fig. 120); “-” without regular relief (Figs 121-122); 29 - egg length.

Пояснение к таблице. 1 - надвидовой таксон: T. - Tanzaniops; J. — Jubabaetis/g3; 2 - вид (первичные родовые названия: A. - Acentrella; B. - Baetis; P. — Pseudocloeon; Pl. — Platybaetis); 3-29 — признаки: 3 - “+” лоб с густыми щетинками (рис. 124); “-” лоб без густых щетинок; 4- “+” мандибулы ножевидные (рис. 136, 137, 154, 155, 168, 169, 193, 194, 202, 203); “-” мандибулы не ножевидные (рис. 102, 141, 142); 5 - “+” левая мола с очень маленькими стебельчатыми выступами (рис. 136, 154, 168193, 202); “-” левая мола с обычными крупными выступами (рис. 102); 6 (параглоссальные мышцы ментума) - “/”" косые (рис. 39, 101, 152); “||” параллельно глоссальным мышцам (рис. 128); 7 (мышца второго членика лабиального щупика) - “+” имеется (рис. 39, 128, 152); “-” отсутствует (рис. 101); 8 (пронотум личинки) — “Р” сигиллы, если имеются, позитивные, т.е. темные на светлом фоне (рис.133 ); “N” сигиллы, если имеются, негативные, т.е. светлые на темном фоне; 9 (субфуркальные выступы на средне- и заднегруди личинки) — “+” заметные; “-” маленькие или отсутствуют; 10-11 - отношение длины голени и бедра у личинки; 12 отношение длины щетинок к ширине голени у личинки; 13 (второй ряд щетинок на задней голени личинки) - “+” имеется (рис. 89); “_” отсутствует (рис. 104); 14 (длинная предвершинная щетинка на лапке личинки) —-“”” имеется (рис. 192); “-” отсутствует (рис. 48); 15 - число зубцов на коготке личинки; 16 (предвершинные щетинки на коготке личинки) - “+” две хорошо развитые щетинки у вершины (рис. 32); “-” щетинки вестигиальные или не достигают вершины (рис. 47); 17 - отношение ширины расправленного II тергита брюшка между основаниями тергалий к его длине; 18 - число дорсальных шипов или бугров на всех или некоторых тергитах брюшка личинки; 19 (форма поля зубчатых бугорков на стернитах брюшка личинки) - "- -" маленькие и поперечные (рис. 99); “/”" крупнее и косые (рис. 113); “> <“ крупнее, косые и объединенные с полями на заднем крае стернита (рис. 23); “\#\#” соединенные медиально и покрывающие большую часть стернита; “士” поля зубчатых выступов маленькие и поперечные, но остальная часть стернита покрыта незубчатыми бугорками (рис. 59); 20-21 - отношение длины и ширины средней тергалии к длине тергита; $22-$ число члеников личиночного парацерка; 23 (плавательные щетинки на внутренней стороне личиночных церков) - “+” имеются (рис. 94); “-” полностью отсутствуют; “(-)” отсутствуют, но сохраняются следы их оснований (рис. 156, 166, 167$)$; 24 (заднее крыло) - “+” имеется (рис. 29-31); “-” отсутствует; 25 (положение имагинальных и субимагинальных крыльев в покое) - “|”” подняты вверх; “- " распростёрты в стороны (рис. 201); 26 - число шипоносных члеников на передней лапке самки имаго и субимаго; 27 - число шипоносных члеников на средней и задней ноге имаго и субимаго; 28 (поверхность яйца) - “\#” с сетчатым рельефом (рис. 118-119); “”” с продольными гребнями (рис. 120); “-” без правильного рельефа (рис. 121-122); 29 — длина яйца. 
al row is present in two species belonging to the plesiomorphon Acentrella/fg2, and in some species of Liebebiella/g1; this allows to conclude, that species which have this additional row, do not form a holophylum, but are dispersed within Acentrella/fg1. Outside of Acentrella/fg1, this additional setal row is not found, so potential to its occurrence can be an autapomorphy of Acentrella/fg1.

(4) Surface of larval abdominal terga lacks wide scales (which are characteristic for Turbanoculata); it can bare only long membranous scales, whose bases are as small as bases of hairs (the same in Baetiella and some other taxa).

(5) Larval paracercus is more or less reduced, never longer than $1 / 2$ of cerci; in most species paracercus is vestigial, many times shorter than cerci, consists either of one, or of a few segments.

Among the species examined, only gnom [Pseudocloeon] has paracercus as long as $1 / 2$ of cerci, with vestiges of primary swimming setae (Fig. 80); in other species primary swimming setae are absent, and paracercus consists either of several segments (Fig. 76), or of a single segment (Figs 18). Various species differ by mode of larval/subimaginal transformation of paracercus: it can transform with or without wastes. In the first case only a part of tissues of larval paracercus give raise to subimaginal paracercus [which is always one-segmented - see Liberevenata (6)]; tissues of its distal part degenerate and their wastes are shed, reminding inside larval exuviae; such molt with wastes occurs if larval paracercus is either multisegmented (Fig. 75), or consists of one elongate segment (Fig. 178). In the second case, if larval paracercus consists of one short segment, it transforms to subimaginal paracercus completely, without wastes.

Judging by distribution of these characters among species of Acentrella/fg1, they are repeatable and reversible, i.e. in course of evolution larval paracercus was repeatedly shortened and repeatedly elongated; in some species (e.g., charadra [Acentrella]) these characters vary individually. So in Acentrella/fg1 characters connected with paracercus reduction can not be used for phylogenetic analysis (Table 2) (but the same characters are good apomorphies in some other mayfly groups).

ADULT CHARACTERS:

(6) In imago and subimago anteronotal protuberance is often conic and sharply projected upward; its shape is variable; usually in lateral view it has well expressed anteriordorsal side, which is more or less straight and much longer than its posterior-dorsal side. Angle between the anteriordorsal and the posterior-dorsal sides can be acute and well expressed, directed dorsally (Figs 26, 90, 129, 145, 146), but sometimes this angle is obtuse, rounded and poorly expressed (Figs 40, 130); in bispinosa [Acentrella], cylindroculata [Acentrella], mamasae [Platybaetis] and wallacei [Platybaetis] this character is poorly expressed, and anteronotal process is always low (Figs 159, 184); in chantauensis [Baetis] this character is not expressed at all, and anteronotal protuberance is non-projected, shallow (Fig. 56).

Besides Acentrella/fg1, similarly projected anteronotal protuberance occurs in some other taxa. Such projected anteronotal protuberance of Heterocloeon was regarded to be a synapomorphy with Acentrella [Waltz, 1994]. The same character occurs in dubia Walsh, 1862 [Cloe], which is recently attributed to Plauditus. Relationship between Acentrella/fg1, Heterocloeon and Plauditus is matter of discussion. The same projected anteronotal protuberance occurs in some evidently non-related taxa, belonging to Baetungulatanon-Baetofemorata (Deceptiviosa and Camelobaetidius) and to Protopatellata (an undescribed African species).
(7) Hind wing, if present, is very narrow, always lacks costal projection, has no more than 2 longitudinal veins, in female is smaller than in male (Figs 29-31, 49-51); in this case larva has narrow protoptera, whose size is different in male and female (Figs 18-20). In many species hind wings are completely lost; in this case larva usually has small narrow vestiges of hind protoptera (Fig. 125, 126), rarely lacks hind protoptera at all (in selected individuals of Platybaetis).

Here we are temporarily placing all species with hind wings to the group lapponica of the plesiomorphon Acentrel$\mathrm{la} / \mathrm{fg} 2$. Hind wings are absent in all species of the groups fenestratum, inexpectatum and sibiricum (also attributed here to the plesiomorphon Acentrella/fg2) and in all species of the holophylum Jubabaetis/g1 (see below). Loss of hind wings and their protoptera repeatedly took place in many phylogenetic branches of Turbanoculata.

(8) $2^{\text {nd }}$ segment of gonostylus usually (but not always) has inner-apical convexity (Figs 1, 38, 57, 70, 77, 87, 96, 97, 109, $114,132,140,149,161,162,197,205)$.

CHARACTER OF LARVAL/SUBIMAGINAL TRANSFORMATION:

(9) In mature larva ready to molt to subimago, buds of subimaginal gonostyli are folded under larval cuticle by the "Acentrella-type" [see Baetovectata (3)]: $2^{\text {nd }}$ and $3^{\text {rd }}$ segments of gonostylus are directed medially so that the posteriormost point locates near joining of $2^{\text {nd }}$ and $3^{\text {rd }}$ segments (Figs 25, 34, $43,44,55,65,78,82,91,106,116,117,131,147,157,163$, 174-176, 183); its early stage of development is shown in Fig. 206. This type of folding is similar to the "Labiobaetis-type", where the posteriormost point locates on the $2^{\text {nd }}$ segment; it occurs in non-related taxa Labiobaetis/g1 (incl. Pseudopannota), Acerpenna and Echinobaetis, belonging to Baetungulatanon-Baetofemorata. In most other taxa of Turbanoculata the posteriormost point locates on the apex of last $\left(3^{\text {rd }}\right)$ segment.

Character of unclear phylogenetic status.

(10) Tarsi of imago and subimago have either maximum number of apical spines [see Tetramerotarsata (1)], or apical spine of the penultimate segment is lost. Maximum number of apical spines occurs in all examined species of the plesiomorphon Acentrella/fg2; probably, this condition is initial for Acentrella/fg1. In this case middle and hind tarsi of both sexes have 3 apical spines, i.e. $1^{\text {st }}+2^{\text {nd }}, 3^{\text {rd }}$ and $4^{\text {th }}$ tarsomeres are spine-bearing (Fig. 5); fore tarsus of female also has 3 apical spines, i.e. $2^{\text {nd }}, 3^{\text {rd }}$ and $4^{\text {th }}$ tarsomeres are spine-bearing (Fig. 4). In all examined species of Jubabaetis/g1 fore tarsus of female has only 2 apical spines, i.e. only $2^{\text {nd }}$ and $3^{\text {rd }}$ tarsomeres are spine-bearing. Among them, in both examined species of Platybaetis middle and hind tarsi of both sexes also have only 2 apical spines, i.e. only $1^{\text {st }}+2^{\text {nd }}$ and $3^{\text {rd }}$ tarsomeres are spine-bearing (Fig. 185). Probably, reduction of the distalmost apical spine took place in these taxa [see below, Jubabaetis/g1 (2) and Platybaetis (4)].

\section{Plesiomorphy.}

(11) The styligeral muscle is retained; it is always unpaired, usually narrow and parallel-sided (Figs 3, 60, 132, 149, 161, 197; Grandi, 1960b: Fig. XV; Grandi, 1960c: Fig. 2). In this respect Acentrella/fg1 differs from Baetosternata (including Baetiella), Labiobaetis/g1 (incl. Pseudopannota), Echinobaetis and Afroptiloides, whose median sterno-styligeral muscle is completely lost.

DISTRIBUTION. Arctogea (Holarctic, Oriental and Ethiopian Regions).

COMPOSITION. The taxon Acentrella/fg1 contains taxa regarded as genera or subgenera Acentrella, Tanzaniops, Liebebiella, Jubabaetis, and Platybaetis. Possibly, here belongs also Demoreptus Lugo-Ortiz \& McCafferty, 1997 
- a genus, established for three African species. LugoOrtiz \& McCafferty [1997] stated that Demoreptus differs from Acentrella, Tanzaniops and related genera by a nonpointed anteronotal process. However, according to their Fig. 2, anteronotal process of Demoreptus capensis has shape well agreeing with variability of this structure in Acentrella/fg1 [see (6)].

Acentrella/fg1 is divided into a plesiomorphon Acentrella/fg2 and a holophyletic taxon Jubabaetis/g1.

\section{C.1.1. Plesiomorphon Acentrella/fg2}

(Figs 1-5, 10-122, 188).

Systematic position: Acentrella/fg1— pm.Acentrella/fg2.

Hierarchical typified name: Acentrella/fg2 (sine Jubabaetis).

Possible ranking names in non-phylogenetic classifications:

— genus Acentrella;

- subgenus Acentrella in genus Acentrella;

- subgenus Acentrella in genus Baetis.

REFERENCES: subgenus Acentrella: Novikova \& Kluge, 1987 (larva); genus Acentrella: Waltz \& McCafferty, 1987b (larva, imago).

Here we temporarily place all Holarctic representatives of Acentrella/fg1. This taxon is generally accepted either as a subgenus Acentrella of the genus Baetis [Novikova \& Kluge, 1987; Tshernova et al., 1986], or as a genus Acentrella [Waltz \& McCafferty, 1987b]. Being characterized by plesiomorphies only, it can be paraphyletic, i.e. ancestral to Jubabaetis/g1.

Plesiomorphies.

(1) Unlike Jubabaetis/g1, flat denticles, which form a row on mola of left mandible, are longer than $1 / 2$ of the distal molar projection and begin close to it (Fig. 102).

(2) Unlike Tanzaniops, mentum has paraglossal muscle oblique and overlapping glossal muscle ventrally (Figs 39, 101).

(3) Unlike Jubabaetis/g2, larval tarsus lacks ventral subapical seta (Fig. 48).

(4) Imaginal and subimaginal tarsus has maximum number of apical spines: middle and hind tarsi of both sexes have 3 apical spines, i.e. $1^{\text {st }}+2^{\text {nd }}, 3^{\text {rd }}$ and $4^{\text {th }}$ tarsomeres are spinebearing (Fig. 5); fore tarsus of female also has 3 apical spines, i.e. $2^{\text {nd }}, 3^{\text {rd }}$ and $4^{\text {th }}$ tarsomeres are spine-bearing (Fig. 4) [see Tetramerotarsata (1) and Acentrella/fg1 (10)]

DISTRIBUTION. Holarctic.

SPECIES COMPOSITION. Here belong Palearctic species: (1) Species with hind wings, which constitute a group lapponica: lapponica Bengtsson, 1912 [Acentrella]; feropagus Alba-Tercedor \& McCafferty, 2000 [Acentrella]; sinaica Bogoescu, 1931 [Acentrella]; charadra Sroka \& Arnekliev, 2010 [Acentrella]; chantauensis Kluge, 1981 [Baetis]; joost Zimmermann \& Braasch, 1979 [Baetis]; and almohades AlbaTercedor \& El-Alami, 1999 [Acentrella]. (2) Two-winged species fenestratum Kazlauskas, 1963 [Pseudocloeon], which forms a group of its own. (3) Group inexpectatum, consisted of 2 two-winged species: inexpectatum Tshernova, 1928 [Pseudocloeon] and gnom Kluge, 1983 [Pseudocloeon]. (4) Group sibiricum, consisted of 3 two-winged species: sibiricum Kazlauskas, 1963 [Pseudocloeon]; diptera sp.n. [Acentrella]; and scabriventris sp.n. [Acentrella].

Probably, to Acentrella/fg2 belongs also latum MüllerLiebenau, 1985 [Pseudocloeon], described as larvae from Taiwan. It lacks hind wings and has similarity with species of sibiricum group; recently it is placed to the genus Acentrella [Waltz \& McCafferty, 1987b].

In North America, besides the species represented in Palearctic (lapponica [Acentrella] and feropagus [Acentrel$l a]$ ), one more species of Acentrella/fg2 with hind wings is reported - insignificans McDunnough, 1926 [Baetis].
Judging by recent redescription by McCafferty, Wigle and Waltz [1994], two-winged North American species turbidum McDunnough, 1924 [Pseudocloeon] (= carolina Banks, 1924 [Cloeon] ) undoubtedly belongs to Acentrella/fg2. Probably, here also belongs two-winged species nadineae McCafferty, Waltz \& Webb, 2009 [Acentrella] known as larvae only. Other two-winged North American species, recently placed to the genus Acentrella, have doubtful systematic position: these are barbarae Jacobus \& McCafferty, 2006 [Acentrella] (whose larval tibiae lack the regular row of setae; alahua Berner, 1940 [Pseudocloeon] and parvulum McDunnough, 1932 [Pseudocloeon] (objective synonym: armillatus McCafferty \& Waltz 1990 [Baetis]), which are placed either to the genus Plauditus Lugo-Ortiz \& McCafferty, 1998, or to Acentrella [Wiersema, 2000].

\section{Key to Palearctic species of Acentrella/fg2}

Larva

1(14) Hind protoptera present (in female smaller than in male) (Figs 18-20) (group lapponica).

2(7) Setae, forming regular row on femur and tibia, short: on tibia less than $1 / 2$ of tibia width (Figs 35-37, 52).

3(4) Paracercus 1-segmented. Each claw with 2 subapical setae (as in Fig. 32). feropagus [Acentrella]

4(3) Paracercus 10-15-segmented. Claws without subapical setae.

5(6) Mature larva usually has characteristic hypodermal pigmentation, visible through cuticle: each abdominal segment I-VIII with a pair of dark brown transverse stripes close to hind margin (Fig. 58)..... chantauensis [Baetis]

6(5) Abdominal hypoderm unicolor. ............ joosti [Baetis]

7(2) Setae, forming regular row on femur and tibia, long: on tibia subequal to tibia width (Figs 18, 46).

8(9) Each claw with 2 subapical setae (Fig. 32). lapponica $[$ Acentrella]

9(8) Claws without subapical setae or with one seta far from apex (Fig. 47).

10(11) Setae forming regular row on femur subequal to $1 / 2$ of femur width............................ almohades [Acentrella]

11(10) Setae forming regular row on femur subequal to femur width.

12(13) Abdominal sterna with a pair of compact, widely separated fields of denticulate protuberances (as in Fig. 99). ............................................. sinaica [Acentrella]

13(12) Abdominal sterna nearly entirely covered with denticulate protuberances. .................. charadra $[$ Acentrella $]$

14(1) Hind protoptera reduced to small vestiges, in which hind wings cannot develop (as in Figs 125-126).

15(16) Paracercus subequal to $1 / 2$ of cerci length, with lateral setae (Fig. 80). Tergalii II-VII long, widest near apex (Fig. 81).................................. gnom [Pseudocloeon]

16(15) Paracercus several times shorter than cerci, without setae. Tergalii widest in middle part.

17(18) Setae, forming regular row on femur and tibia, short: on tibia less than $1 / 2$ of tibia width (Figs 66-69). Cerci lack swimming setae. ....... fenestratun [Pseudocloeon]

18(17) Setae, forming regular row on femur and tibia, long: on tibia equal or longer than tibia width (Figs 79). Cerci with swimming setae.

18(20) Paracercus 3-6-segmented (Fig. 76). Tergalii of middle pairs enlarged, 1.5 times longer than tergalii of pairs I and VII (Fig. 71)....... inexpectatum [Pseudocloeon]

20(18) Paracercus 1-segmented. Tergalii of middle pairs only slightly larger than tergalii of pairs I and VII (Figs 92, 115) (group sibiricum).

21(22) Hind tibia with second regular row of long setae (Fig. 89) sibiricum [Pseudocloeon] 
22(21) Hind tibia without second regular setal row (on its place only irregularly situated setae can be present - Fig. 104).

23(24) Paired fields of denticulate protuberances on abdominal sterna II-VIII transverse and widely separated, locate only laterad of medioposterior sigilla (Fig. 99) ...

diptera $[$ Acentrella $]$

24(23) Paired fields of denticulate protuberances on abdominal sterna II-VIII oblique, locate laterad and posteriad of medioposterior sigilla (Fig. 113).

$$
\text { scabriventris [Acentrella] }
$$

Male imago (imagoes of feropagus [Acentrella], joosti [Baetis] and almohades [Acentrella] are unknown).

1(8) Hind wings present, long and narrow, with 2 longitudinal veins only (Figs 29-31, 49-51). All abdominal segments brown (group lapponica).

2(3) Gonovectes slightly bent, thickened apically (Figs 57 , $60,61)$. chantauensis [Baetis]

3(2) Gonovectes strongly bent, curved apically (Figs 1-3,38).

4(5) Median sclerotized projection on penial bridge roundish, without median concavity (Fig. 38)

charadra $[$ Acentrella $]$

5(4) Median sclerotized projection on penial bridge truncate or with median concavity (Figs $1-3$ ).

6(7) Distal segment of gonostylus about 4 times as long as broad (Figs 1, 3).

lapponica $[$ Acentrella]

7(6) Distal segment of gonostylus about 2 times as long as broad [Müller-Liebenau, 1969: Abb.42b].

sinaica $[$ Acentrella $]$

8(1) Hind wings absent

9(12) Abdominal segments II-VI whitish, segments VIII-X with terga brown. Penial bridge without dark median sclerotization (Figs 77, 87) (group inexpectatum).

10(11) Turban eyes nearly cylindrical (Figs 85, 86). gnom [Pseudocloeon]

11(10) Turban eyes low and wide (Figs 72, 73). inexpectatum $[$ Pseudocloeon $]$

12(9) All abdominal segments brown. Penial bridge with dark median sclerotization (Figs 70, 95-97, 108-109, 114).

13(14) Penial bridge medially sclerotized and somewhat undulate, without distinct projection (Fig. 70).

fenestratun [Pseudocloeon]

14(13) Penial bridge medially with distinct sclerotized projection (Figs 95-97, 108-109, 114) (group sibiricum).

15(16) Sclerotized projection of penial bridge shallow and wide (Fig. 114). .................. scabriventris [Acentrella]

16(15) Sclerotized projection of penial bridge prominent and narrow (Figs 95-97, 108-109).

17(18) Sclerotized projection of penial bridge roundish (Figs 95-97). .............................. sibiricum [Pseudocloeon]

18(17) Sclerotized projection of penial bridge truncate (Figs 108-109). diptera $[$ Acentrella $]$

\section{C.1.1.1. Plesiomorphon: group lapponica} (Figs 1-3, 18-61, 118-119, 188)

Systematic position: Acentrella/fg1-pm.Acentrella/fg2pm.gr.lapponica.

This is a plesiomorphon, which includes all species retaining hind wings. In male hind wings are always long and narrow, with 2 longitudinal veins only; in female hind wings are much smaller than in male (Figs 18-20, 29-31, 49-51) [see Acentrella/fg1 (7)]

SPECIES COMPOSITION: lapponica [Acentrella], feropagus [Acentrella], sinaica [Acentrella], charadra [Acen- trella], chantauiensis [Baetis], joosti [Baetis], almohades [Acentrella] and insignificans [Baetis]. The last two species had not been examined by us.

\section{C.1.1.1-1. Acentrella/fg2 lapponica [Acentrella]} (Figs 1-3, 18-32, 188)

Systematic position: Acentrella/fg1—pm.Acentrella/fg2pm.gr.lapponica.

Original binomen: Acenrella lapponica Bengtsson, 1912

Subjective synonym: Baetis (Acentrella) putoranicus: Novikova, 1987 (manuscript name).

Possible binomina:

- Acenrella lapponica;

- Baetis lapponicus;

- Baetis (Acentrella) lapponicus.

REFERENCES: Acentrella lapponica Bengtsson, 1912 (larva, subimago, imago); Baetis lapponicus: Müller-Liebenau, 1965 (larva, imago); 1969 (larva, imago); Kopelke \& Müller-Liebenau, 1982 (egg); Baetis (Acentrella) lapponicus: Novikova \& Kluge, 1987.

MATERIAL. RUSSIA: Murmansk oblast': Khibin mountains, basin of lake Vud-Yavr, VIII-IX.1931-1937, coll. Fridolin: subimagoes and imagoes. Komi republic: river Syn'-Yu, 1926-1927, coll. Yu. Chernov: many imagoes; river Usa 7-10.VIII.1930, coll. N. Iordanskiy: $9 \mathrm{IO}^{\top}, 2 \mathrm{I}+, 1 \mathrm{~S}+$; Pechora-Ilych natural reserve, 1980-1999, coll. E. Novikova, L. Zhiltzova, O. Loskutova: many larvae, subimagoes and imagoes. Taymyr autonomous okrug, basin of river Khatanga: stream Vodorazdelnyy (left tributary of river Kotuy $9 \mathrm{~km}$ above mouth of river Eriechka), 21-26.VIII.1979: 3 LS-I $\sigma^{7}, 3$ L-S-I +3 L-S $\sigma^{7}, 5$ L-S 9 , 3 larvae. Upper part of river Sabyda, 17-24.VII.1979, coll. N. Kluge: 15 L-S-IO', 15 L-S-Iㅇ, 7 L$\mathrm{S} \sigma^{7}, 9 \mathrm{~L}-\mathrm{S}+, 18$ larvae. River Ekhilyakh (left tributary of river Kotuy $30 \mathrm{~km}$ above mouth of river Medvezh'ya), 30.VII-4.VIII.1979, coll. N. Kluge: 6 L-S-I $\sigma^{7}, 6$ L-S-I,+ 1 L-S $\sigma^{7}, 1$ L-S,+ 1 S ${ }^{7}, 5$ larvae. Tyva (= Tuva) republic, mountain ridge East Tannu-Ola: river Aryskannyg-Khem, 16.IX.1992, coll. V. Zaika: 4 larvae. Magadan, river Dukcha, 9.VIII.1978, coll. A. Mikheev: 1 larva. MONGOLIA: River Boom-gol near Bo-Hongor-Alon, 25.VII.1982, coll. A. Dulmaa: 1 larva. Hovsgol, tributaries of lake Hubsugul (= Hovsgol-nuur): river Alag-Tsar-gol (east of Hatgal), 19.VIII-2.IX.1997, coll. N. Kluge: 4 L-S ${ }^{\top}, 1$ L-S-I,+ 2 L-S +12 larvae; river Ih-Horoo-gol, 25.VII.1989, coll. K. Varykhanova: 15 larvae; river Bayan-gol, 27.IX.1985, coll. K. Varykhanova: 1 larva. Arhangay: streams on northern bank of lake Terhiyn-Tsagaan-Nuur, 27.VIII-2.IX.1997, coll. N. Kluge: 3 L-S-I07, 6 L-S $\sigma^{7}, 2$ L-S-I,+ 3 L-S + , many larvae.

Larva. Cuticular COLORATION: Head and thorax have cuticle brown with lighter and darker areas; pronotum has dark sigilla (as in Fig. 133; [Müller-Liebenau, 1969: Abb.43]). Thoracic pleura dark, sterna colorless. Abdominal terga brown with diffusive light blanks; medioposterior sigilla often darker than background, on anterior terga slightly transverse, on posterior terga round (as in Fig. 110; [Müller-Liebenau, 1969: Abb.43]); sterna at most part light. Femora light with diffusive brownish areas; tibiae and tarsi brown, apices of tarsi darker. Cuticle of cerci uniformly brownish.

HyPODERMAL COLORATION: Hypoderm without contrasting markings.

SHAPE AND SETATION: Frons somewhat projected above clypeus, without dens setae. Labrum has medium proportions, its length somewhat exceeds $1 / 2$ of width [Müller-Liebenau, 1969: Abb.46a]. Mandibles not blade-like (as in Fig. 102, [Müller-Liebenau, 1969: Abb.46b]). Labium as in Fig. 39, with paraglossal muscle oblique and fan-like; $2^{\text {nd }}$ palpomere with muscle; $3^{\text {rd }}$ palpomere wide, rounded, with length subequal to width [Müller-Liebenau, 1969: Abb.46d]. Thoracic sterna have no prominent subfurcal protuberances. Hind protoptera present, in female much smaller than in male (Figs 1820). Legs moderately long and slender. Femora of all legs have subequal length. On fore and middle leg length of tibia subequal to length of femur; on hind leg tibia slightly shorter. 
Tarsus of middle and hind leg about 2.5 times shorter than femur; tarsus of fore leg in female slightly longer, in male 1.2 times longer. Femur width about $1 / 4$ of femur length; tibia width about 0.13 of tibia length. Patella occupies about $1 / 2$ of inner tibial margin, or less. Setae forming the regular row on external margin of femur have length about $1 / 5$ of femur width. Setae forming the regular row on dorsal margin of tibia [see Acentrella/fg1 (3)] long, subequal to tibia width; second (external) row of setae absent. Tarsus lacks row of setae. Claw has 8-10 denticles, with two well developed subapical setae (Fig.

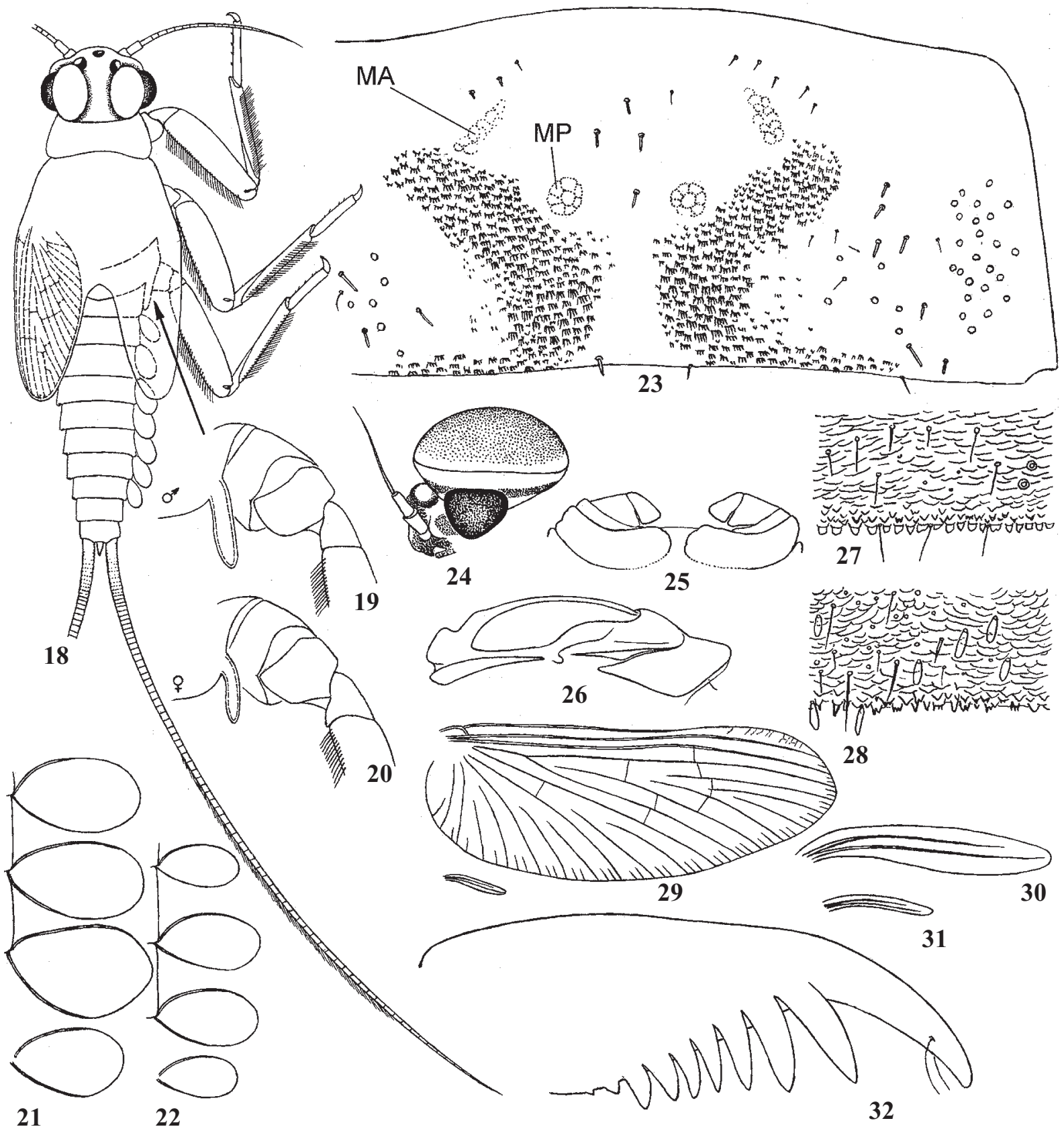

Figs 18-32. Acentrella/fg2 lapponica [Acentrella]: 18 - mature male larva, dorsal view; 19 - right part of its metathorax with hind protopteron; 20 - the same, mature female larva; $21-22$ - tergalii I-III and VII of two specimens; 23 - larval exuviae of abdominal sternum VI (specimen from Magadan); 24 - head of male imago, lateral view; 25 - buds of subimaginal gonostyli folded under larval cuticle; 26 imaginal mesonotum, lateral view; 27 - posterior margin of larval abdominal tergum VI, specimen from Northern Urals; 28 - the same, specimen from Taimyr; 29 - fore and hind wings of male imago; 30-31 — hind wings of male and female imagoes; 32 - larval claw.

Рис. 18-32. Acentrella/fg2 lapponica [Acentrella]: 18 - зрелая личинка самца, дорсально; 19 - правая половина её заднегруди с задним протоптероном; 20 - то же, зрелая личинка самки; 21-22 - I-III и VII тергалии двух экземпляров; 23- личиночный экзувий VI стернита брюшка (экземпляр из Магадана); 24 - голова самца имаго, латерально; 25 - зачатки субимагинальных гоностилей, сложенные под личиночной кутикулой; 26 - имагинальный мезонотум, латерально; 27 - задний край VI тергита брюшка личинки, экземпляр с Северного Урала; 28 - то же, экземпляр с Таймыра; 29 - переднее и заднее крылья самца имаго; $30-31$ - задние крылья самца и самки имаго; $32-$ коготок личинки. 
32). Abdominal terga widened: width of spread abdominal tergum II between tergalii bases 4-5 times exceeds its length. Abdominal terga either lack scales (specimens from Urals Fig. 27), or with oval translucent scales (specimens from Siberia - Fig. 28); posterior margins of terga with blunt or split denticles. Paired sternal fields of dentate protuberances variable: either locate only laterad of medioposterior sigilla (as in most species and similar to Fig. 99), or spread mediallybackward (similar to Fig. 113), or integrate with paired fields of dentate protuberances behind them, forming a pair of U-like figures with branches directed laterally (Fig. 23), or form a pair of large fields; unlike charadra [Acentrella], these fields are never connected medially. Tergalii of all pairs subequal, usually not large, oval, with length somewhat exceeding tergum length and width less than tergum length (Figs 21-22). Vestige of paracercus usually short and one-segmented, subimaginal vestige of paracercus develops in it without wastes; some specimens from Ih-Horoo-gol have paracercus longer, having up to 6 segments and developing with wastes. Cerci subequal to body length. Primary swimming setae developed: absent on about two dozens proximal segments; one or a few on each next segment; about 6 setae with pressed transverse bases on each middle segment; absent on several last segments.

Subimago. Cuticular coloration. Thoracic sclerites brown. Cuticle of legs brown. Cuticle of abdomen light brownish. Wings light.

HyPODERMAL COLORATION. As in imago.

Imago, male. Head and thorax brown. Turban eyes wide (Fig. 24), orange. All legs either uniformly brownish, or ocher with distal part of femur diffusively darkened. On fore leg femur longer than in larva; tibia 1.6 of femur length; tarsus 1.4 of femur length. On middle and hind legs femur and tarsus have the same length as in larva; tibiae 1.25 longer than in larva. On middle and hind legs tarsus has 3 apical spines: $1^{\text {st }}+2^{\text {nd }}, 3^{\text {rd }}$ and $4^{\text {th }}$ tarsomeres are spine-bearing (as in Fig. 5) [see Acentrella/fg2 (4)]. Fore wing has basal sclerites brown; veins light; pterostigma colorless, with about 10 incomplete

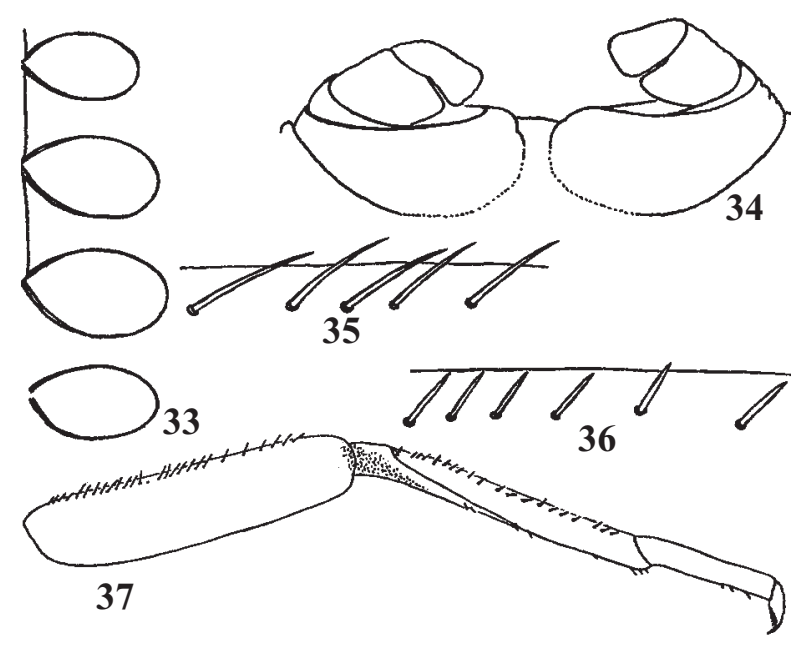

Figs 33-37. Acentrella/fg2 feropagus [Acentrella], larva: 33 tergalii I-III and VII; 34 - buds of subimaginal gonostyli folded under larval cuticle; 35 - setae on outer margin of femur; 36 - setae on outer margin of tibia; 37 - middle leg.

Рис. 33-37. Acentrella/fg2 feropagus [Acentrella], личинка: 33 - I-III и VII тергалии; 34 - зачатки субимагинальных гоностилей, сложенные под личиночной кутикулой; $35-$ щетинки на наружном крае бедра; 36 - щетинки на наружном крае голени; 37 - средняя нога. crossveins. Hind wings long and narrow, with 2 longitudinal veins (Figs 29, 30). Abdomen uniformly brown. Gonostyli brown. Length of $3^{\text {rd }}$ (distal) segment varies from $1 / 2$ to $2 / 3$ of length of $2^{\text {nd }}$ segment; penial bridge medially with a prominent wide trapezoid sclerotized projection; gonovectes brown, thick and short; styligeral muscle narrow (Figs 1-3). Cerci in proximal part brownish.

Imago, female. Coloration as in male. On fore leg tarsus has 3 apical spines: $2^{\text {nd }}, 3^{\text {rd }}$ and $4^{\text {th }}$ tarsomeres are spinebearing (Fig. 4); on middle and hind legs tarsus also has 3 apical spines: $1^{\text {st }}+2^{\text {nd }}, 3^{\text {rd }}$ and $4^{\text {th }}$ tarsomeres are spine-bearing (Fig. 5) (as in male) [see Acentrella/fg2 (4)]. Hind wings smaller than in male (Fig. 31).

Egg. Length about $0.14 \mathrm{~mm}$. Chorion with reticulation: entire surface consists of concave cells separated by narrow walls and arranged in nearly regular transverse rows [Kopelke \& Müller-Liebenau, 1982: Abb.37-38].

Dimension. Fore wing length 5-6 mm.

DISTRIBUTION. Fennoscandia, Northern Urals, East Siberia, Mongolia and Russian Far East.

\section{C.1.1.1-2. Acentrella/fg2 feropagus [Acentrella]} (Figs 33-37)

Systematic position: Acentrella/fg1—pm.Acentrella/fg2pm.gr.lapponica.

Original binomen: Acenrella feropagus Alba-Tercedor \& McCafferty 2000.

Possible binomina:

- Acenrella feropagus;

- Baetis feropagus;

- Baetis (Acentrella) feropagus.

REFERENCES: Baetis lapponicus: Morihara \& McCafferty, 1979 (non Acentrella lapponica Bengtsson, 1912) (larva); Acentrella feropagus Alba-Tercedor \& McCafferty, 2000 (larva).

MATERIAL. RUSSIA: Wrangel island, delta of river Mamontovaya $3 \mathrm{~km}$ above mouth, 4.VIII.1979, coll. E. Makarchenko: many larvae. Sakha Republic (Yakutiya): delta of river Lena, Olenekskaya Protoka, island Samoilovsky, lake Samoilovskoye, 20.VII.1988, coll. Gukov: many larvae; river Kengdey (right tributary of River Lena), 8.VIII.1989, coll. Gukov: 25 larvae.

Larva. SHAPE AND SETATION: Body moderately widened. Frons somewhat projected above clypeus, without dens setae. Labrum has medium proportions, its length somewhat exceeds 1/2 of width. Mandibles not blade-like (as in Fig. 102). Labium as in Fig. 39, with paraglossal muscle oblique and fan-like; $2^{\text {nd }}$ palpomere with muscle; $3^{\text {rd }}$ palpomere wide, rounded, with length subequal to width. Thoracic sterna have no prominent subfurcal protuberances. Hind protoptera present, in female much smaller than in male (as in Figs 1820). Legs moderately long and slender (Fig. 37). Femur width about $1 / 4$ of femur length; tibia width about 0.13 of tibia length. Patella occupies about $1 / 2$ of inner tibial margin. Setae forming the regular row on external margin of femur have length less than 1/3 of femur width (Fig. 35). Setae forming the regular row on dorsal margin of tibia [see Acentrella/fg1 (3)] short, subequal to $1 / 2$ of tibia width; second (external) row of setae absent (Fig. 36). Claws with 9-13 denticles, with 2 well developed subapical setae. Abdominal terga moderately widened: width of spread abdominal tergum II between tergalii bases only 4 times exceeds its length. Abdominal terga without scales, hind margins of terga with blunt denticles (as in Fig. 27). Paired sternal fields of dentate protuberances small, locate laterad or laterad-anteriad of medioposterior sigilla (as in Fig. 97). Tergalii not large, tergalii of all pairs subequal (Fig. 33). Vestige of paracercus short and one-segmented, subimaginal vestige of paracercus develops in it without wastes. Cerci subequal to body length, with vestigial primary swimming setae. 
Imago and subimago. Unknown. Judging by subimaginal parts extracted from mature larvae, on middle and hind legs of male and female tarsus has 3 apical spines: $1^{\text {st }}+2^{\text {nd }}, 3^{\text {rd }}$ and $4^{\text {th }}$ tarsomeres are spine-baring; on fore leg of female tarsus also has 3 apical spines: $2^{\text {nd }}, 3^{\text {rd }}$ and $4^{\text {th }}$ tarsomeres are spine-bearing (as in Figs 4, 5) [see Acentrella/fg2 (4)]. Styligeral muscle narrow (as in Fig. 3).

Dimension. Fore wing length (extracted from mature larva) $5 \mathrm{~mm}$.

DISTRIBUTION. Arctic cost and islands of East Siberia and North America.

\section{C.1.1.1-3. Acentrella/fg2 sinaica [Acentrella]}

Systematic position: Acentrella/fg1—pm.Acentrella/fg2pm.gr.lapponica.

Original binomen: Acentrella sinaica Bogoescu, 1931.

Subjective synonyms:

- Baetis subatrebatinus Grandi, 1956.

- Baetis pseudatrebatinus Grandi, 1960

Possible binomina:

- Acenrella sinaica;

- Baetis sinaicus;

- Baetis (Acentrella) sinaicus.

REFERENCES: Acentrella sinaica Bogoescu, 1931; Bogoescu \& Tabacaru, 1957 (larva); Bogoescu, 1958 (imago); Ujhelyi, 1959 (imago). Baetis atrebatinus: Grandi, 1948 (non Eaton 1870) (larvula, larva subimago, imago). Baetis subatrebatinus Grandi, 1956. Baetis pseudatrebatinus Grandi, 1960a (imago, lava); 1960b (genitals); 1960c (genitals). Baetis sinaicus (= Baetis subatrebatinus): Müller-Liebenau, 1969 (larva, imago); Kopelke \& Müller-Liebenau, 1982 (egg).

MATERIAL. ITALY, Emilia Romagna, Vernasca (Piacenza), Torrente Stirone, 22.V.2004, coll. C. Belfiore: 9 larvae.

Larva. SHAPE AND SETATION: Body widened. Frons somewhat projected above clypeus, without dens setae. Labrum has medium proportions, its length somewhat exceeds $1 / 2$ of width. Mandibles not blade-like (as in Fig. 102). Labium as in Fig. 39, with paraglossal muscle oblique and fan-like; $2^{\text {nd }}$ palpomere with muscle; $3^{\text {rd }}$ palpomere wide, rounded, with length subequal to width. Thoracic sterna have no prominent subfurcal protuberances. Hind protoptera present, in female much smaller than in male (as in Figs 18-20). Legs moderately long and slender: femur width about $1 / 4$ of femur length; tibia width about 0.12 of tibia length. Patella occupies $1 / 5$ of inner tibial margin. Setae forming the regular row of on external margin of femur dense and long, with length subequal to femur width; near apex of femur located densely and irregularly. Setae forming the regular row on dorsal margin of tibia [see Acentrella/fg1 (3)] long, with length exceeding tibia width; second (external) row of setae absent. Claws with 7-9 denticles; subapical setae vestigial, but have well-developed sockets. Abdominal terga widened: width of spread abdominal tergum II between tergalii bases 4-5 times exceeds its length. Abdominal terga with long narrow translucent scales, hind margins of terga with cleft denticles (as in Fig. 28). Paired sternal fields of dentate protuberances transverse, narrow, locate laterad or laterad-anteriad of medioposterior sigilla (as in Fig. 99). Tergalii not large, oval, with length somewhat exceeding tergum length and width subequal to tergum length. Paracercus vestigial, one-segmented, subimaginal vestige of paracercus develops in it without wastes. Cerci subequal to body length, with vestigial primary swimming setae.

Imago. Described by Grandi [1948] (as "Baetis atrebatinus") and Müller-Liebenau [1969]; not examined by us.

Dimension. Fore wing length 4-6 mm.

Egg. According to description by Kopelke \& Müller-Liebenau [1982], about $0.15 \mathrm{~mm}$; chorion with striation, i.e. entire surface consists of numerous thin longitudinal ridges separated by grooves [Kopelke \& Müller-Liebenau, 1982: Abb.41-46].

DISTRIBUTION. Southern and Central Europe (France, Switzerland, Italy, Romania, Czechia, Poland) and Asia Minor.

\section{C.1.1.1-4. Acentrella/fg2 charadra [Acentrella]}

(Figs 38-51)

Systematic position: Acentrella/fg1— pm.Acentrella/fg2pm.gr.lapponica.

Original binomen: Acentrella charadra Sroka \& Arnekliev, 2010.

Subjective synonym: Baetis (Acentrella) squamatus: Noviko-

va, 1987 (manuscript name).

Possible binomina:

- Acenrella charadra;

- Baetis charadrus;

- Baetis (Acentrella) charadrus.

REFERENCES: Novikova, 1987: Baetis (Acentrella) squamatus (larva, female imago); Acentrella charadra Sroka \& Arnekliev, 2010 (larva).

MATERIAL. RUSSIA, Altay republic, river Chuya near KoshAgach, 28.VII-4.VIII.1987, coll. N. Kluge: 27 L-S-IO', 12 L-S-I +1 L-S $\sigma^{\top}, 1$ L-S 9,1 I $^{\prime}, 7$ larvae. KAZAKHSTAN, river Chu near mouth of river Kuragaty, 19.VI.1986, coll. N. Kluge: 1 L-SI . MONGOLIA, river Tuin-gol near Bogd, 4.IX.1997, coll. N. Kluge: $1 \mathrm{~L}-\mathrm{S} \bigcirc, 2$ larvae. Ovorhangay: river Orhon-gol near Harhorin, 3-4.IX.1997, coll. N. Kluge: 1 L-S-IO'.

Larva. Cuticular COloration: Head and thorax have cuticle brown with diffusive lighter and darker areas; pronotum has dark sigilla (as in Fig. 133). Thoracic pleura dark, sterna colorless. Abdominal terga brown with diffusive light blanks; medioposterior sigilla slightly darker than background, often poorly expressed, on anterior terga slightly transverse, on posterior terga round (as in Fig. 110); sterna lighter brown. Femora light with diffusive brownish areas; tibiae light; fore tarsi and apices of middle and hind tarsi darker. Cuticle of cerci uniformly light.

HyPODERMAL COLORATION: Hypoderm without contrasting markings.

SHAPE AND SETATION: Frons somewhat projected above clypeus, without dens setae. Labrum has medium proportions, its length somewhat exceeds $1 / 2$ of width (as in Fig. 111). Mandibles not blade-like (as in Fig. 102). Labium with paraglossal muscle oblique and fan-like; $2^{\text {nd }}$ palpomere with muscle; $3^{\text {rd }}$ palpomere wide, rounded, with length subequal to width (Fig. 39). Thoracic sterna have no prominent subfurcal protuberances. Hind protoptera present, being larger in male and smaller in female (as in Figs 18-20). Legs have femora relatively wide: femur width more than $1 / 3$ of femur length. Femora of all legs have subequal length. On all legs length of tibia subequal to length of femur. Tarsus of middle and hind leg 0.5 of femur length; tarsus of fore leg longer, 0.7 of femur length. Tibia and tarsus relatively thick: tibia width about 0.17 of length. Patella occupies slightly more than $1 / 2$ of inner tibial margin. Setae forming the regular row of on external margin of femur long, subequal to femur width. Setae forming the regular row on dorsal margin of tibia [see Acentrella/fg1 (3)] long, subequal to tibia width; second (external) row of setae absent. Tarsus on dorsal side with numerous long projected scales of variable shape - bandlike, oval, truncate et al. (Fig. 48) (unlike other Acentrella/ fg1). Claws with 8-10 small denticles; subapical setae either vestigial, or small and do not reach apex of claw (Fig. 47). Abdominal terga widened: width of spread abdominal tergum II between tergalii bases 5 times exceeds its length. Abdominal terga with large translucent scales, many of which truncate, with serrate hind margin; hind margins of terga lacks distinctly expressed denticles (Fig. 45). Denticulate protuberances on all abdominal sterna occupy most part of ster- 


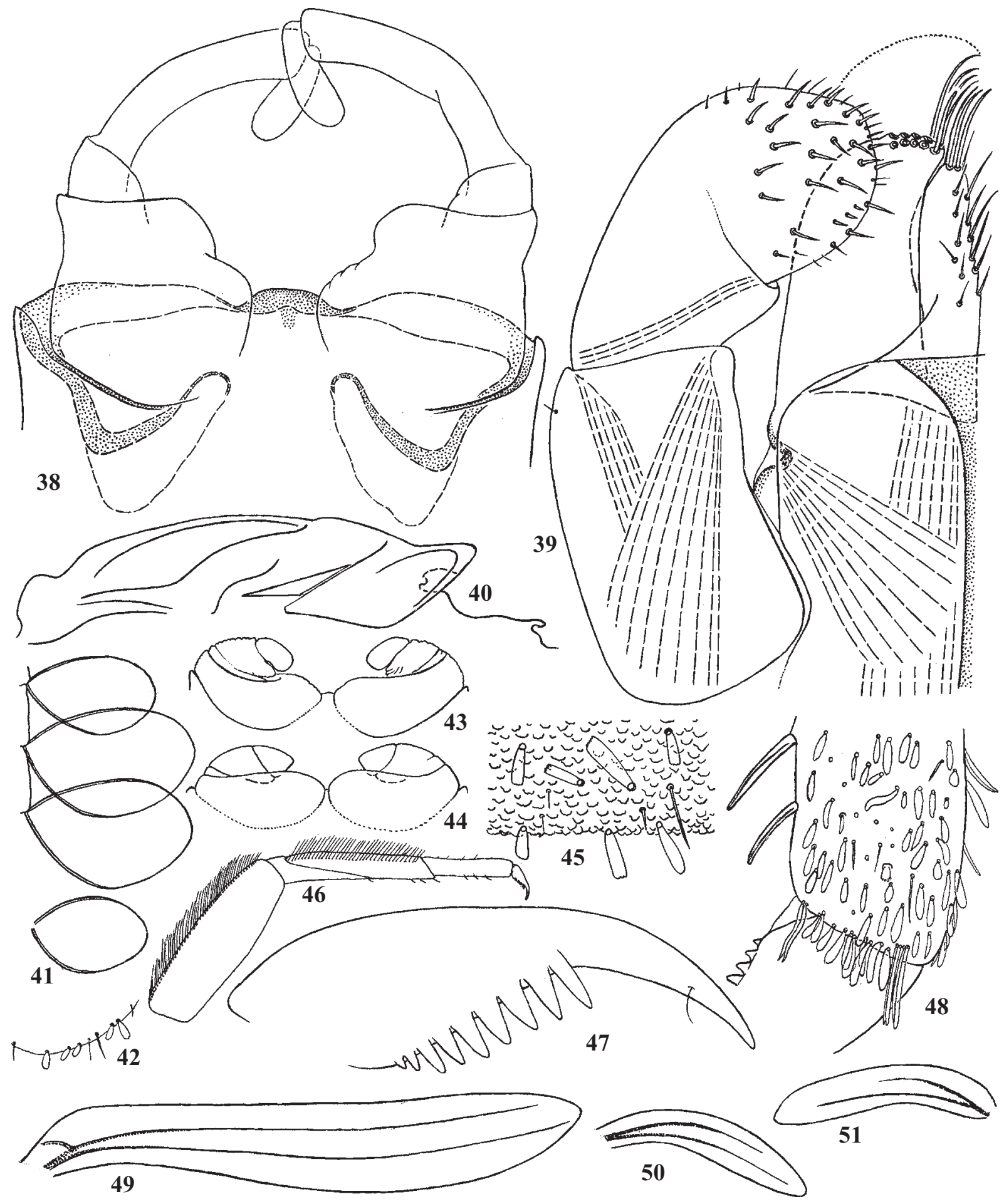

Figs 38-51. Acentrella/fg2 charadra [Acentrella]: 38 — genitals of male imago, ventral view (muscles not shown); 39 — half of labium, ventral view (muscles shown by interrupted lines); 40 - imaginal mesonotum, lateral view; 41 - tergalii I-III and VII; 42 - margin of tergalium; 43-44 - buds of subimaginal gonostyli folded under larval cuticle; 45 - posterior margin of larval abdominal tergum VI; 46 larval middle leg; 47 - larval claw; 48 - tip of larval tarsus; 49 - hind wing of male imago; 50-51 — the same, female imago.

Pис. 38-51. Acentrella/fg2 charadra [Acentrella]: 38 — гениталии самца имаго, вентрально (мышцы не показаны); 39 — половина нижней губы, вентрально (мышцы показаны прерывистыми линиями); 40 — имагинальный мезонотум, латерально; 41 - тергалии I-III и VII; 42 - край тергалии; 43-44 - зачатки субимагинальных гоностилей, сложенные под личиночной кутикулой; 45 - задний край VI тергита брюшка личинки; 46 - средняя нога личинки; 47 — коготок личинки; 48 - вершина лапки личинки; 49 - заднее крыло самца имаго; 50-51 - то же, самка имаго. 
num, being absent only on medioposterior sigilla and on anterior part of sternum (unlike compact fields of such protuberances in Figs 23, 99 and 113). Tergalii large, oval; tergalii of middle pairs about 2 times longer than terga, with width exceeding tergum length, much larger than tergalii of anterior and posterior pairs (Fig. 41). Margins of tergalii, besides thin setae (which present in other species), bear oval translucent scales. Paracercus vestigial, without swimming setae; its structure has unusually wide variability: from one-segmented to multisegmented; subimaginal vestige of paracercus develops in it either without or with wastes. Specimens from KoshAgach (in Altai) and Orhon-gol (in Mongolia) have paracercus short, consisted of 1-6 segments; subimaginal vestige of paracercus develops in it either without or with wastes. The single specimen from Chu (in Kazakhstan) and 3 specimens from Tuin-gol (in Mongolia) have paracercus longer, 12-15 segmented, 6 times shorter than cerci; subimaginal vestige of paracercus develops in it with wastes. Cerci subequal to body length. Primary swimming setae developed: absent on about a dozen proximal segments; one or a few on each next segment; about 10 setae with pressed transverse bases on each middle segment; absent on several last segments.

Subimago. Cuticular Coloration. Thoracic sclerites brown. Cuticle of legs light brownish, with knees and tarsi darker. Cuticle of abdomen light brownish. Wings light.

Hypodermal coloration. As in imago.

Imago, male. Head and thorax brown. Turban eyes low and wide (as in Fig. 24), yellow. All legs light brownish, with distal part of femur and base of tibia diffusively darkened. On fore leg femur 1.1 times longer than in larva; tibia 1.7 of femur length; tarsus longer than femur, ca. 1.6 of femur length. On middle and hind leg femur and tarsus have length as in larva; tibia 1.1 times longer than in larva and subimago. On middle and hind legs tarsus has 3 apical spines: $1^{\text {st }}+2^{\text {nd }}, 3^{\text {rd }}$ and $4^{\text {th }}$ tarsomeres are spine-baring (as in Fig. 5) [see Acentrella/fg2 (4)]. Fore wing has basal sclerites dark brown; veins light; pterostigma colorless, with about 10 incomplete crossveins. Hind wings long and narrow, with 2 longitudinal veins. Abdominal terga and sterna nearly uniformly brown. Styliger and gonostyli light brownish or colorless. Each unistyliger has median side convex, inner-distal margin projected; penial bridge medially with a prominent wide roundish sclerotized projection; gonovectes brown, thick and short (Fig. 38); styligeral muscle narrow (as in Fig. 3). Cerci uniformly light.

Imago, female. Head and thorax ocher-brown, lighter than in male. Femora ocher, in distal part diffusively darkened; tibiae and tarsi colorless. On fore leg tarsus has 3 apical spines: $2^{\text {nd }}, 3^{\text {rd }}$ and $4^{\text {th }}$ tarsomeres are spine-baring; on middle and hind legs tarsus also has 3 apical spines: $1^{\text {st }}+2^{\text {nd }}, 3^{\text {rd }}$ and $4^{\text {th }}$ tarsomeres are spine-baring (as in male) (as in Figs 4, 5) [see Acentrella/fg2 (4)]. Hind wing smaller than in male.

Egg. Length about $0.14-0.15 \mathrm{~mm}$. Chorion with reticulation: entire surface consists of concave cells separated by narrow walls and arranged in nearly regular transverse rows (as in Figs 118-119).

Dimension. Fore wing length 5-6 mm.

DISTRIBUTION. Probably, desert zone of Central Asia: Muyunkum desert in Kazakhstan, desert zone of Altai, Gobi desert in Mongolia.

COMPARISON. Larva of charadra [Acentrella] differs from other species by presence of integral unpaired field of denticulate protuberances on each abdominal sternum; from lapponica $[$ Acentrella $]$ it differs also by smaller denticles on claws, absence of subapical setae on claws, usually larger tergalii, usually longer paracercus and numerous translucent scales on legs. Male imago of charadra [Acentrella] differs from lapponica [Acentrella] by absence of median concavity on median projection of penial bridge.

\section{C.1.1.1-5. Acentrella/fg2 chantauensis [Baetis]}

(Figs 52-61, 118-119)

Systematic position: Acentrella/fg1— pm.Acentrella/fg2pm.gr.lapponica.

Original binomen: Baetis chantauensis Kluge, 1981.

Possible binomina:

- Acenrella chantauensis;

- Baetis chantauensis;

- Baetis (Acentrella) chantauensis.

REFERENCES: Baetis chantauensis Kluge, 1981 (larva, imago); Baetis (Acentrella) chantauensis: Novikova \& Kluge, 1987; Acentrella chantauensis: Waltz \& McCafferty, 1987b.

MATERIAL. KAZAKHSTAN: Zhambulskaya oblast' (= Dzhambul province), Moyunkum region, small stream $12 \mathrm{~km} \mathrm{~W}$ Khantau, 16.VI.1978, coll. N. Kluge: 1 L-S-I $\sigma^{7}$ (holotype), 6 L-S $\sigma^{7}$, 5 L-S,+ 5 I ${ }^{7}, 6$ I 9,3 S ${ }^{7}, 2$ S,+ 15 L; South Kazakhstan, Karatau Ridge, road Kentau - Chulakkurgan, near Achisay, 4-6.V.1988, coll. V. Lukhtanov: $1 \mathrm{I} / \mathrm{S} \sigma^{7}$

Larva. Cuticular COlORATION: Head and thorax have cuticle brown with diffusive lighter and darker areas; pronotum has dark sigilla (as in Fig. 133). Thoracic pleura dark, sterna colorless. Abdominal terga brown with diffusive light blanks; medioposterior sigilla slightly darker than background, often poorly expressed, on anterior terga slightly transverse, on posterior terga round (as in Fig. 110); sterna lighter brown. Femora light with diffusive brownish areas; tibiae and tarsi with dark outer margins, apices of tarsi darkened. Cuticle of cerci uniformly brown.

HyPODERMAL COLORATION: Abdomen of mature larva can have characteristic hypodermal color as in imago (see below).

SHAPE AND SETATION: Body moderately widened. Frons somewhat projected above clypeus, without dens setae. Labrum has medium proportions, its length somewhat exceeds $1 / 2$ of width (as in Fig. 111). Mandibles not blade-like (as in Fig. 102). Labium as in Fig. 39, with paraglossal muscle oblique and fanlike; $2^{\text {nd }}$ palpomere with muscle; $3^{\text {rd }}$ palpomere wide, rounded, with length subequal to width. Thoracic sterna have no prominent subfurcal protuberances. Hind protoptera present, in female much smaller than in male (as in Figs 18-20). Legs moderately long and slender: femur width about $1 / 4$ of femur length. Tibia and tarsus relatively thick: tibia width about 0.18 of tibia length. Femora of all legs have subequal length. Tibia shorter than femur: on fore leg about 0.9 of femur length, on hind leg about 0.8 of femur length. Tarsus of middle and hind leg 0.5 of femur length; tarsus of fore leg longer, 0.7 of femur length. Patella occupies slightly more than $1 / 2$ of inner tibial margin. Setae forming the regular row of on external margin of femur have length about $1 / 4$ of femur width. Setae forming the regular row on dorsal margin of tibia [see Acentrella/fg1 (3)] short, about 1/ 3 of tibia width, not much longer than irregularly situated setae of tibia; second (external) row of setae absent. Claws with 10-13 denticles; subapical setae vestigial, but have well-developed sockets. Abdominal terga moderately widened: width of spread abdominal tergum II between tergalii bases only 4 times exceeds its length. Abdominal terga without scales, hind margins of terga partly without denticles, partly with serrate vestigial denticles. Fields of denticulate protuberances on abdominal sterna rather compact (similar to Fig. 99), but hardly distinguishable among numerous non-denticulate protuberances (Fig. 59), which entirely cover abdomen and other body parts - head, thoracic terga and pleura, legs. Tergalii not large, elongate-oval, 1.5-2 times longer than terga, with width less than tergum length. Paracercus vestigial, without swimming setae, but mult- 
isegmented (consists of 10-13 segments); subimaginal vestige of paracercus develops in it with wastes. Cerci subequal to body length. Primary swimming setae developed: absent on a 1-3 proximal segments; one or a few on each next segment; about 10 setae with pressed transverse bases on each middle segment; absent on several last segments.

Subimago. Cuticular coloration. Thoracic sclerites brown. Cuticle of femora and tibia light brown, patella and tarsi darker. Cuticle of abdomen brown. Wings light.

HYPODERMAL COLORATION. As in imago.

Imago, male. Head and thorax dark brown. Turban eyes not high, wide (Figs 53-54), orange-yellow. Anteronotal protuberance shallow (Fig. 56) (unlike other Acentrella/ fg1). Fore legs dark brown; middle and hind legs yellowish, each femur with diffusive brown spot at $1 / 4$ from apex. On fore leg femur only slightly longer than in larva; tibia 1.4 of femur length; tarsus longer than femur, about 1.3 of femur length (ratio femur / tibia / tarsomeres 35:52:15:14:8:7) On middle and hind leg femur and tarsus have length as in larva; tibia 1.1 times longer than in larva and subimago. On middle and hind legs tarsus has 3 apical spines: $1^{\text {st }}+2^{\text {nd }}, 3^{\text {rd }}$ and $4^{\text {th }}$ tarsomeres are spine-baring (as in Fig. 5) [Acentrella/fg2 (4)]. Fore wing has basal sclerites dark brown; veins light; pterostigma colorless, with about 10 incomplete crossveins. Hind wing long and narrow, with 2 longitudinal veins, reach III abdominal segment. Abdomen ocher-brown, non-translucent; terga I-VIII with dark brown transverse stripe near hind margin, especially well expressed by sides and often interrupted medially. Gonostylus with $1^{\text {st }}$ segment either conic or cylindrical (Figs 57, 60) [Kluge, 1981: Fig. $3]$; $3^{\text {rd }}$ segment large, widened apically. Penial bridge medially with a prominent truncate sclerotized projection (Figs 57, 60). Gonovectes have structure different from other Baetovectata: only slightly arched, entirely pigmented and lack membranous widenings (unlike other species), with apices widely rounded and pigmented (Figs 57, 60, 61). Styligeral muscle narrow (Fig. 60). Cerci ocher-whitish, unicolor.

Imago, female. Head, thorax and abdomen ocher-brown. Hind wings smaller than in male, reach only abdominal segment I. On fore leg tarsus has 3 apical spines: $2^{\text {nd }}, 3^{\text {rd }}$ and $4^{\text {th }}$ tarsomeres are spine-baring; on middle and hind legs tarsus also has 3 apical spines: $1^{\text {st }}+2^{\text {nd }}, 3^{\text {rd }}$ and $4^{\text {th }}$ tarsomeres are spine-baring (as in male) (as in Figs 4, 5) [see Acentrella/ fg2 (4)]. Abdominal color pattern as in male.

Egg. Length $0.15 \mathrm{~mm}$. Chorion with reticulation: entire surface consists of concave cells separated by narrow walls and arranged in regular transverse rows (Figs 118-119).

Dimension. Fore wing length 3-5 $\mathrm{mm}$.

DISTRIBUTION. Known from two points in Kazakhstan.

\section{C.1.1.1-6. Acentrella/fg2 joosti [Baetis]}

Systematic position: Acentrella/fg1—pm.Acentrella/fg2 pm.gr.lapponica.

Original binomen: Baetis joosti Zimmermann \& Braasch, 1979.

Possible binomina:

- Acenrella joosti;

- Baetis joosti;

- Baetis (Acentrella) joosti.

REFERENCES: Baetis joosti Zimmermann \& Braasch, 1979 (larva); Baetis (Acentrella) joosti: Novikova \& Kluge, 1987.

MATERIAL. ARMENIA, Razdan, 10.VIII.1977, coll. Zimmermann: 3 q mature larvae (paratypes).

COMMENTS. Imago unknown. Larvae are very similar to chantauensis $[B$.]; differ from chantauensis $[B$.] by larger size and unicolor abdominal hypoderm of mature larva, which lacks paired dark transverse stripes, characteristic for chantauensis $[B$.].

Judging by subimaginal parts extracted from mature larvae, on middle and hind legs tarsus has 3 apical spines: $1^{\text {st }}+2^{\text {nd }}, 3^{\text {rd }}$ and $4^{\text {th }}$ tarsomeres are spine-baring; on fore leg of female tarsus also has 3 apical spines: $2^{\text {nd }}, 3^{\text {rd }}$ and $4^{\text {th }}$ tarsomer-

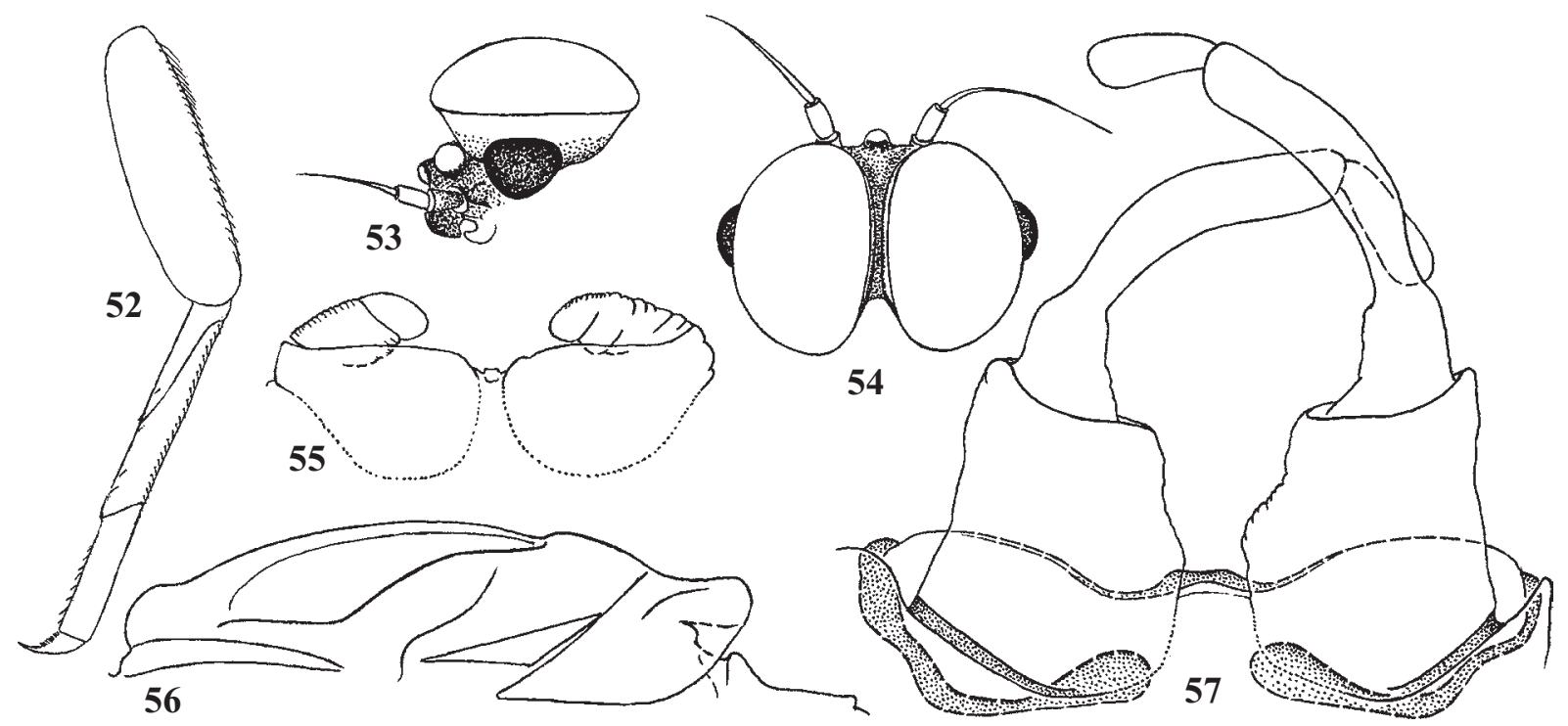

Figs 52-57. Acentrella/fg2 chantauensis [Baetis]: 52 — larval middle leg; 53 - male imaginal head, lateral view; 54 — the same, dorsal view; 55 - buds of subimaginal gonostyli folded under larval cuticle; 56 - imaginal mesonotum, lateral view; 57 - genitals of male imago, ventral view (muscles not shown).

Pис. 52-57. Acentrella/fg2 chantauensis [Baetis]: 52 - средняя нога личинки; 53 - голова самца имаго, латерально; 54 - то же, дорсально; 55 - зачатки субимагинальных гоностилей, сложенные под личиночной кутикулой; 56 - имагинальный мезонотум, латерально; 57 - гениталии самца имаго, вентрально (мышцы не показаны). 
es are spine-bearing [see Acentrella/fg2 (4)]. Egg has the same structure as in chantauensis [B.].

\section{C.1.1.2. Group fenestratum}

(Figs 10-13, 62-70)

Systematic position: Acentrella/fg $1-\mathrm{pm}$.Acentrella/fg2gr.fenestratum

This group differs from others by complete loss of swimming setae and their vestiges on larval cerci. Hind wings absent

SPECIES COMPOSITION: a single species - fenestratum [Pseudocloeon].

\section{C.1.1.2-1. Acentrella/fg2 fenestratum [Pseudocloeon]}

(Figs 10-13, 62-70)

Systematic position: Acentrella/fg $1-\mathrm{pm}$.Acentrella/fg2gr.fenestratum

Original binomen: Pseudocloeon fenestratum Kazlauskas, 1963.

Possible binomina:

- Acenrella fenestrata

- Baetis fenestratus;

- Baetis (Acentrella) fenestratus.

REFERENCES: Pseudocloeon sp. Nr 2: Sukackiene, 1962 (larva). Pseudocloeon fenestratum Kazlauskas, 1963 (larva); Kluge, 1980 (larva, imago). Baetis (Acentrella) fenestratus: Tshernova et al., 1986 (imago); Novikova \& Kluge, 1987; Kluge, 1997b (larva). Acentrella fenestrata: Waltz \& McCafferty, 1987b.
MATERIAL. RUSSIA: Taymyrskiy (Dolgano-Nenetskiy) autonomnyy okrug (= Taymyr autonomous region), upper part of river Sabyda, 8-24.VII.1979, coll. N. Kluge: 5 L-S-IO7, 5 L-S-Iㅇ, 36 larvae. Irkutskaya oblast' (Irkutsk province), river Kotinka (west tributary of Lake Baikal), 17.VI.1959: 1 larva (holotype). Republic Byryatia, Baikal natural reserve, river Anosovka, 23.VII.1998, coll. N. Rozhkova: 1 larva. Republic Sakha (Yakutia), shore of Olenekskiy zaliv (= Olenek bay), Ystynakh-Khocho, lake Olimpiyskoe (= Olympic), 24.VIII.1986, coll. Chukov: 4 larvae.

Larva. Cuticular coloration: Head and thorax have cuticle brown with diffusive lighter and darker areas; pronotum has dark sigilla (as in Fig. 133). Thoracic pleura dark, sterna colorless. Abdominal terga brown with diffusive light blanks; medioposterior sigilla darker than background, round (as in Fig. 110); sterna at most part light. Femora light with diffusive brownish areas; tibiae light; fore tarsi and apices of middle and hind tarsi darker. Cuticle of cerci unicolor or darkened distally

HYPODERMAL COLORATION: Hypoderm without contrasting markings.

SHAPE AND SETATION: Body moderately widened (Figs 10 13). Frons somewhat projected above clypeus, without dens setae. Labrum has medium proportions, its length somewhat exceeds $1 / 2$ of width (as in Fig. 111). Mandibles not blade-like (as in Fig. 102). Labium as in Fig. 39, with paraglossal muscle

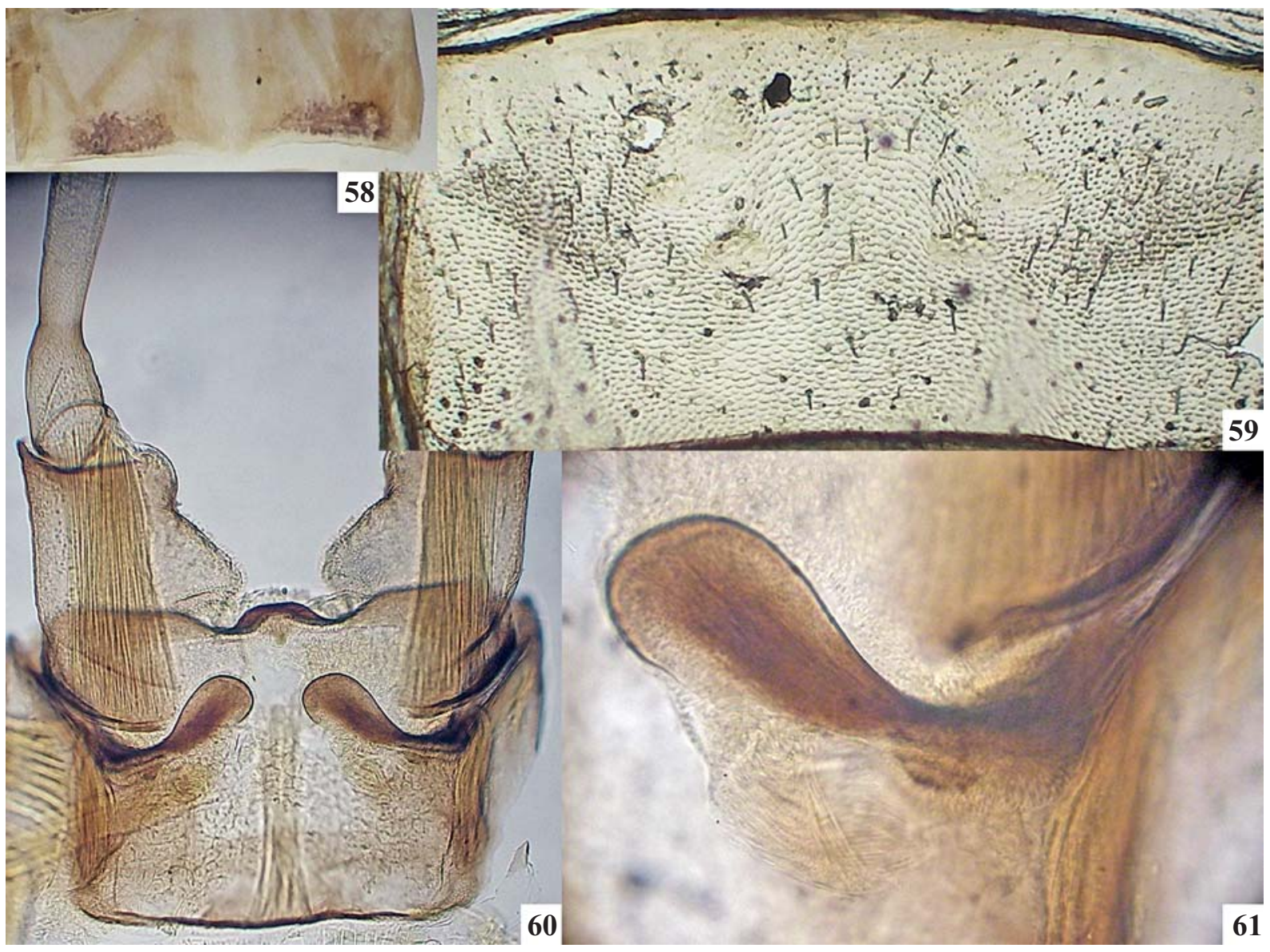

Figs 58-61. Acentrella/fg2 chantauensis [Baetis]: 58 - abdominal tergum $\mathrm{V}$ of male imago, spread on slide; 59 — larval exuviae of abdominal sternum VI; 60 - genitals of male imago, ventral view; 61 - gonovectis.

Рис. 58-61. Acentrella/fg2 chantauensis [Baetis]: 58 - V тергит брюшка самца имаго, расправлен на препарате; 59 — личиночный экзувий VI стернита брюшка; 60 — гениталии самца имаго, вентрально; 61 — гоновектис. 
oblique and fan-like; $2^{\text {nd }}$ palpomere with muscle $; 3^{\text {rd }}$ palpomere wide, rounded, with length subequal to width. Thoracic sterna have no prominent subfurcal protuberances. Hind protoptera reduced to small vestiges (as in Fig. 125). Legs long and slender: femur width less than $1 / 4$ of femur length. Femora of all legs have subequal length. On all legs length of tibia subequal to length of femur. Tarsus of middle and hind leg 0.55 of femur length; tarsus of fore leg slightly longer, 0.5 of femur length. Patella occupies about $1 / 2$ of inner tibial margin. Setae forming the regular row of on external margin of femur no longer than $1 / 5$ of femur width. Setae forming the regular row on dorsal margin of tibia [see Acentrella/fg1 (3)] short, shorter than $1 / 2$ of tibia width; second (external) row of setae absent. Claws with 9-13 denticles; subapical setae vestigial. Abdominal terga moderately widened: width of spread abdominal tergum II between tergalii bases only 4 times exceeds its length. Abdominal terga without scales, hind margins of terga with cleft denticles (Fig. 63). Paired sternal fields of dentate protuberances transverse, narrow, locate in front of medioposterior sigilla, just behind medioanterior sigilla (more anteriorly than in Fig. 99). Tergalii not large, elongate, 1.5-1.8 times longer than terga, with width less than tergum length (Fig. 62). Paracercus vestigial, 1-3-segmented, subimaginal vestige of paracercus develops in it without wastes. Cerci subequal to body length; primary swimming setae and their sockets completely absent.

Subimago. Cuticular coloration. Thoracic sclerites brown. Cuticle of legs light brownish, with knees and tarsi darker. Cuticle of abdomen light brownish. Wings light.

HYPODERMAL COLORATION. As in imago.

Imago, male. Head and thoracic sclerites dark brown. Turban eyes not high, wide (Fig. 64), yellow-orange or yellow. Legs yellow-brown. On fore leg femur 1.1 times longer than in larva; tibia 1.5 of femur length; tarsus longer than femur, ca. 1.6 of femur length (fore leg has ratio femur / tibia / tarsal segments $=20: 32: 12: 10: 6: 4)$. On middle and hind leg femur and tarsus have length as in larva; tibia 1.1 times longer than in larva and subimago. On middle and hind legs tarsus has 3 apical spines: $1^{\text {st }}+2^{\text {nd }}, 3^{\text {rd }}$ and $4^{\text {th }}$ tarsomeres spine-baring (as in Fig. 5) [see Acentrella/fg2 (4)]. Fore wing has basal sclerites brown; veins light; pterostigma colorless, with about 10 crossveins often incomplete. Abdomen yellowish-brown, middle segments translucent; terga slightly darker than sterna. $1^{\text {st }}$ segment of gonostylus slightly narrowed toward apex, $2^{\text {nd }}$ segment widened toward apex, $3^{\text {rd }}$ segment curved; penial bridge medially sclerotized and somewhat undulate, without distinct projection; gonovectes sharply bent (Fig. 70). Styligeral muscle narrow (as in Fig. 3). Cerci uniformly pale.

Imago, female. Lighter than in male: head and thorax yellowish-brown, abdomen yellowish. On fore leg tarsus has 3 apical spines: $2^{\text {nd }}, 3^{\text {rd }}$ and $4^{\text {th }}$ tarsomeres are spine-baring; on middle and hind legs tarsus also has 3 spines: $1^{\text {st }}+2^{\text {nd }}, 3^{\text {rd }}$ and $4^{\text {th }}$ tarsomeres are spine-bearing (as in male) (as in Figs 4, 5) [see Acentrella/fg2 (4)].

Egg. Large, length $0.22-0.25 \mathrm{~mm}$. Surface without striation or reticulation, with fine irregular roughness only (as in Fig. 121).

Dimension. Fore wing length 4-5 mm.

DISTRIBUTION. East Siberia and Russian Far East.

\section{C.1.1.3. Group inexpectatum}

(Figs 71-87, 120)

Systematic position: Acentrella/fg1-pm.Acentrella/fg2gr.inexpectatum.

Larval characters: Pronotum has light sigilla on darker background (unlike dark sigilla on lighter background, charac-

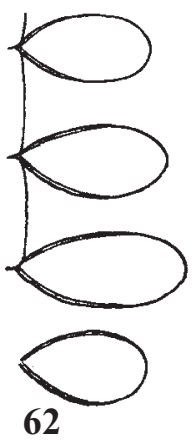

$\Longrightarrow \rightleftharpoons A$

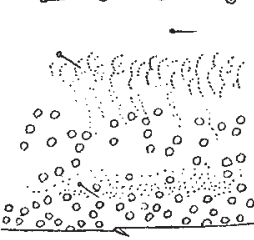

66

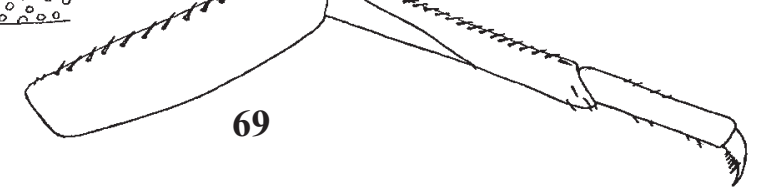

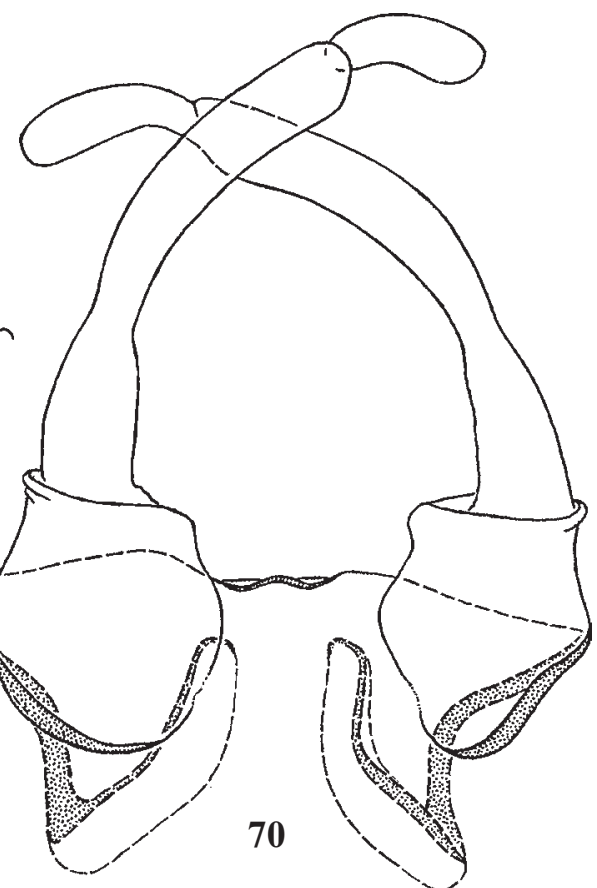

70

Figs 62-70. Acentrella/fg2 fenestratum [Pseudocloeon]: 62 - tergalii I-III and VII; 63 - posterior margin of larval abdominal tergum VI; 64 - head of male imago, lateral view; 65 — buds of subimaginal gonostyli folded under larval cuticle; 66-68 — fragments of larval femur, tibia and tarsus; 69 - larval middle leg; 70 - genitals of male imago, ventral view (muscles not shown).

Рис. 62-70. Acentrella/fg2 fenestratum [Pseudocloeon]: 62 - тергалии I-III и VII; 63 — задний край VI тергита брюшка личинки; 64 голова самца имаго, латерально; 65 - зачатки субимагинальных гоностилей, сложенные под личиночной кутикулой; 66-68 - участки бедра, голени и лапки личинки; 69 - средняя нога личинки; 70 - гениталии самца имаго, вентрально (мышцы не показаны). 
teristic for most Acentrella/fg1). Tergalii II-V enlarged, so that tergalius II much larger than tergalius I; cerci shorter than in most Acentrella/fg1, with swimming setae beginning nearly from the base; paracercus multisegmented; legs not as long as in other Acentrella/fg1, tibiae shortened, hind tibiae markedly shorter than fore ones (see Table 2).

Male imaginal characters: middle abdominal segments light, translucent, while terga VII-X dark (the same in many other Turbanoculata, but not in other known Acentella/fg1); penial bridge lacks median sclerotized projection. Egg with longitudinal ridges. Hind wings absent.

SPECIES COMPOSITION: two species - inexpectatum [Pseudocloeon] and gnom [Pseudocloeon].

\section{C.1.1.3-1. Acentralla/fg2 inexpectatum [Pseudocloeon]} (Figs 71-79, 120)

Systematic position: Acentrella/fg1 - pm.Acentrella/fg2gr.inexpectatum.

Original binomen: Pseudocloeon inexpectatum Tshernova, 1928

Subjective synonym: Pseudocloeon hyalopterum Bogoescu, 1951. Possible binomina:

- Acenrella inexpectata

- Baetis inexpectatus;

- Baetis (Acentrella) inexpectatus.

REFERENCES: Pseudocloeon inexpectatum Tshernova, 1928 (female imago); Tshernova, 1964 (male imago); Kazlauskas, 1977 (larva). Pseudocloeon hyalopterum Bogoescu, 1951 (female imago); Bogoescu \& Tabacaru, 1957 (larva). Baetis (Acentrella) inex- pectatus: Novikova \& Kluge, 1987; Kluge, 1997b (larva). Acentrella inexpectata: Jacob, 1991 (male imago).

MATERIAL. RUSSIA: Moskovskaya oblast' (= Moscow province), river Moskva (= Moscow) near Zvenigoroid, 12.VII.1922, 21.VIII.1924, 3-12.VIII.1926, coll. S. Tshernov: 4 I 9 (including lectotype), 1 intersex imago. Krasnodarskiy kray (= Krasnodar territory), river Zelenchuk at its fall to river Kuban' in Nevinnomyssk: 1 larva. Komi republic, river Pechora, 29.VII.1925, coll. O. Tshernova: 1 IO', 1 I 9 . Bashkortostan (= Bashkiria), river Ik, 23.VII.1986, coll. N. Kluge \& E. Novikova: 5 L-S-I $0^{7}, 4$ L-S-I 9 , 2 L-S $\odot^{7}, 1$ L-S

Larva. Cuticular COlORATION: Head and thorax have cuticle light brownish with lighter and darker areas; pronotum has poorly expressed light sigilla on darker background (negative, if compare with Fig. 133). Thoracic pleura dark, sterna colorless. Abdominal terga brown with various light blanks; medioposterior sigilla poorly expressed, round (as in Fig. 110); sterna at most part light. Legs light. Cerci light, distally darkened.

Hypodermal Coloration: Hypoderm without contrasting markings.

SHAPE AND SETATION: Body moderately widened. Frons somewhat projected above clypeus, without dens setae. Labrum has medium proportions, its length somewhat exceeds $1 / 2$ of width (as in Fig. 111). Mandibles not blade-like (as in Fig. 102). Labium as in Fig. 39, with paraglossal muscle oblique and fanlike; $2^{\text {nd }}$ palpomere with muscle; $3^{\text {rd }}$ palpomere wide, rounded, with length subequal to width. Thoracic sterna have no prominent subfurcal protuberances. Hind protoptera reduced to small
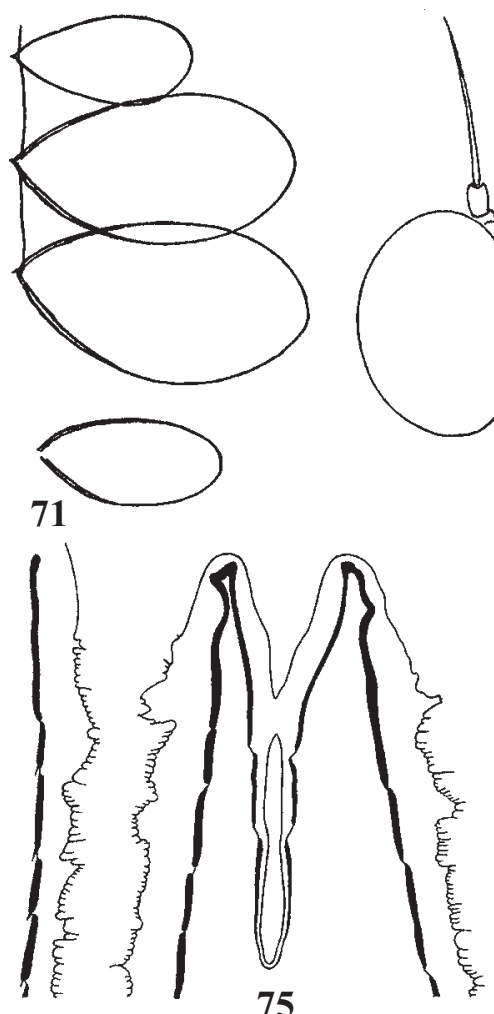

75

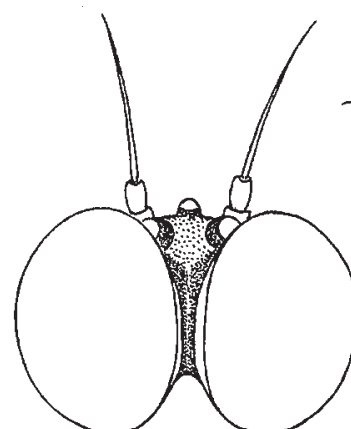

72

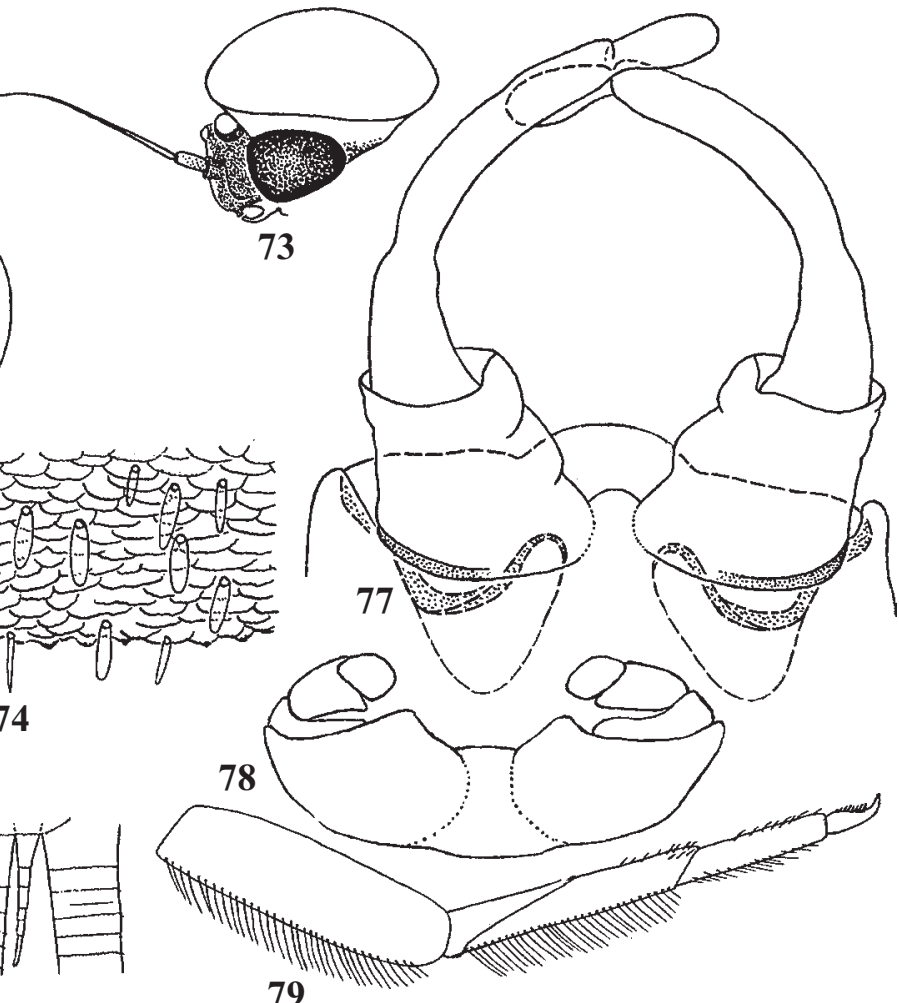

79

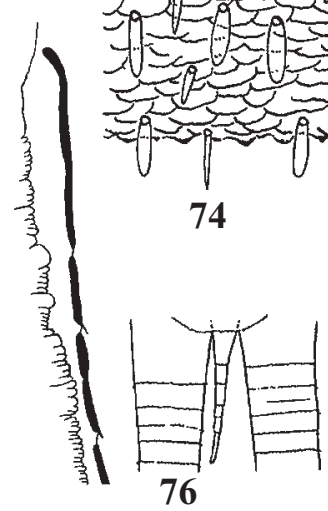

Figs 71-79. Acentrella/fg2 inexpectatum [Pseudocloeon]: 71 - tergalii I-III and VII; 72 - head of male imago, dorsal view; 73 - the same, lateral view; 74 - posterior margin of larval abdominal tergum VI; 75 - developing of subimaginal cerci and paracercus under larval cuticle; 76 - larval paracercus; 77 - genitals of male imago, ventral view (muscles not shown); 78 — buds of subimaginal gonostyli folded under larval cuticle; 79 - larval middle leg.

Pис. 71-79. Acentrella/fg2 inexpectatum [Pseudocloeon]: 71 — тергалии I-III и VII; 72 — голова самца имаго, дорсально; 73 — то же, латерально; 74 - задний край VI тергита брюшка личинки; 75 - субимагинальные церки и парацерк, развивающиеся под личиночной кутикулой; 76 - парацерк личинки; 77 - гениталии самца имаго, вентрально (мышцы не показаны); 78 - зачатки субимагинальных гоностилей, сложенные под личиночной кутикулой; 79 - средняя нога личинки. 
vestiges (as in Fig. 125). Legs thick: femur width about $1 / 3$ of femur length; tibia width about 1/5 of tibia length. Femora of all legs have subequal length. On fore leg length of tibia shorter than femur, $0.8-0.9$ of femur length; on middle leg tibia shorter and on hind leg shorter, about $0.6-0.7$ of femur length. Tarsus of middle and hind leg 0.5 of femur length; tarsus of fore leg longer, 0.6 of femur length. Patella occupies more than $1 / 2$ of inner tibial margin. Setae forming the regular row of on external margin of femur long, with length exceeding $1 / 2$ of femur width. Setae forming the regular row on dorsal margin of tibia [see Acentrella/fg1 (3)] long, with length equal or exceeding tibia width; second (external) row of setae absent. Claws with 9-10 denticles; subapical setae vestigial. Abdominal terga moderately widened: width of spread abdominal tergum II between tergalii bases only 4 times exceeds its length. Abdominal terga with large oval translucent scales, hind margins of terga without distinctly expressed denticles (Fig. 74). Paired sternal fields of dentate protuberances transverse, narrow, locate only laterad of medioposterior sigilla (as in Fig. 99). Tergalii of middle pairs relatively large, oval, 2-3 times longer than tergum, with width 1.5 times exceeding tergum length, 1.5 times longer than tergalii of pairs I and VII (Fig. 71). Paracercus vestigial, without swimming setae, but multisegmented (can have 3-6 segments) (Fig. 76); subimaginal vestige of paracercus develops in it with wastes (Fig. 75). Cerci subequal 2/3 of body length. Primary swimming setae well-developed: absent on 1-2 proximal segments; one or a few on each next segment; about 12 setae with pressed transverse bases on each middle segment; absent on several last segments.

Subimago. Cuticular coloration. Thoracic sclerites brown. Cuticle of legs light. Cuticle of abdomen light brownish. Wings light.

HYPODERMAL COLORATION. As in imago.

Imago, male. Head and thorax dark brown. Turban eyes low and wide (Figs 72-73), yellow. Legs pail, fore femur darkened. On fore leg femur 1.15 times longer than in larva; tibia 1.5 of femur length; tarsus longer than femur, ca. 1.4 of femur length. On middle and hind leg femur has length as in larva; tibia 1.5 times longer than in larva and subimago; tarsus 1.1-1.2 times longer than in larva. On middle and hind legs tarsus has 3 apical spines: $1^{\text {st }}+2^{\text {nd }}, 3^{\text {rd }}$ and $4^{\text {th }}$ tarsomeres are spine-bearing (as in Fig. 5) [see Acentrella/fg2 (4)]. Fore wing has basal sclerites dark brown; veins light; pterostigma colorless, with several incomplete crossveins. Hind wings absent. Abdominal segments II-VI white; segments VII-X have terga dark brown, sterna whitish with brown spots by sides and on basal part of unistyligers. Gonostyli whitish. Penial bridge medially lacks sclerotized projection; gonovectes brown, slightly bent (Fig. 77); styligeral muscle narrow (as in Fig. 3). Cerci whitish.

Imago, female. Head, thorax and abdomen dorsally yellowocher, ventrally paler. Legs pale; fore femur dark ocher, with apex light. On fore leg tarsus has 3 apical spines: $2^{\text {nd }}, 3^{\text {rd }}$ and $4^{\text {th }}$ tarsomeres are spine-bearing; on middle and hind legs tarsus also has 3 apical spines: $1^{\text {st }}+2^{\text {nd }}, 3^{\text {rd }}$ and $4^{\text {th }}$ tarsomeres are spinebearing (as in male) (as in Figs 4, 5) [see Acentrella/fg2 (4)].

Egg. Length about $0.18-0.2 \mathrm{~mm}$. Chorion with striation: entire surface consists of numerous thin longitudinal ridges separated by grooves.

Dimension. Fore wing length $5 \mathrm{~mm}$.

DISTRIBUTION. Europe and Urals.

\section{C.1.1.3-2. Acentralla/fg2 gnom [Pseudocloeon]} (Figs 78-87)

Systematic position: Acentrella/fg1—pm.Acentrella/fg2gr.inexpectatum.

Original binomen: Pseudocloeon gnom Kluge, 1983.
Subjective synonym: Pseudocloeon ultimum Müller-Liebenau, 1985.

Possible binomina:

- Acenrella gnom;

- Baetis gnom;

- Baetis (Acentrella) gnom.

REFERENCES: Pseudocloeon gnom Kluge, 1983 (larva, imago); Pseudocloeon ultimum Müller-Liebenau, 1985 (larva); Baetis (Acentrella) gnom: Tshernova et al., 1986 (imago); Novikova \& Kluge, 1987; Kluge, 1997b (larva); Acentrella gnom (= Pseudocloeon ultimum): Waltz \& McCafferty, 1987b.

MATERIAL. RUSSIA: Chitinskaya oblast' (= Chita province), river Ingoda near Alexandrovka, 30.VII-1.VIII.1994, coll. N. Kluge: 5 L-S-I $\sigma^{\top}, 1$ L-S-I,+ 3 L-S ${ }^{\top}, 2$ L-S $\odot, 3$ larvae. Primorskiy kray (Primorye territory): river Ussuri near Novo-Chuguevka, 24.VIII.1980, coll. N. Kluge: $1 \mathrm{~L}-\mathrm{S}$; ; close to natural reserve "Kedrovaya Pad", river Barabashevka (= Mongugay), 28.VI-4.VII.1980, coll. N. Kluge: 10 L-S-I $\sigma^{7}$ (including holotype), 1 L-S-I 9,20 larvae; same area, river Narva (= Sidime), 12-20.VII.1980, coll. N. Kluge: 2 L-S-IO’. JAPAN: Pref. Gifu, river Nagara, 18.X.1978, coll. A. Ponomarenko: 1 larva; Hirishima-city, Uokiri, Asakita-ku, river Yoshiyama, 20.VII.2000, coll. I. Tatarenko: 1 larva.

Larva. Cuticular COloration: Head and thorax have cuticle light brownish with lighter and darker areas; pronotum has poorly expressed light sigilla on darker background (Fig. 80; negative, if compare with Fig. 133). Thoracic pleura dark, sterna colorless. Abdominal terga II-VIII nearly uniformly light brownish, with medial longitudinal blank close to anterior margin; medioposterior sigilla poorly expressed, round (as in Fig. 110). Terga IX-X and all sterna at most part light. Legs light; femur with large diffusive brownish macula at middle; articulations and apex of tarsus darkened. Cerci and paracercus light.

HyPODERMAl COLORATION: Hypoderm without contrasting markings.

Shape And SETATION: Body moderately widened. Frons somewhat projected above clypeus, without dens setae. Labrum short, length equal $1 / 2$ of width. Mandibles not blade-like, short, incisor and kinetodontium approximated with mola. Labium with paraglossal muscle oblique and fan-like. Labial palp short and wide; $2^{\text {nd }}$ palpomere with muscle; $3^{\text {rd }}$ palpomere has length less than width. Mesosternum and metasternum each with a pair of pointed conic subfurcal protuberances. Hind protoptera reduced to small vestiges $0.05 \mathrm{~mm}$ length (as in Fig. 125). Legs thick (Fig. 83): femur width about $1 / 3$ of femur length; tibia width about 0.14-0.18 of tibia length. Femora of all legs have subequal length. On fore leg tibia either equal or shorter than femur ( 0.9 of femur length); on middle leg tibia shorter and on hind leg shorter, about 0.7 of femur length. Tarsus of middle and hind leg 0.5 of femur length; tarsus of fore leg longer, 0.6 of femur length. Patella occupies more than $1 / 2$ of inner tibial margin. Setae forming the regular row of on external margin of femur long, with length subequal to femur width. Setae forming the regular row on dorsal margin of tibia [see Acentrella/fg1 (3)] long, with length exceeding tibia width; second (external) row of setae absent. Tarsus with less long setae on outer margin, which form nearly regular row. Claws with 811 denticles; subapical setae vestigial. Abdominal terga widened: width of spread abdominal tergum II between tergalii bases 4-5 times exceeds its length. Abdominal terga with numerous long translucent scales; hind margins of terga without distinctly expressed denticles (Fig. 84). Paired sternal fields of dentate protuberances transverse, narrow, locate only laterad of medioposterior sigilla (as in Fig. 99). Tergalii of pair I short, oval; tergalii II-VII long and narrow, widened toward apex (Fig. 81). Paracercus long, subequal 1/2 of cerci length, with vestiges of primary swimming setae (Fig. 80) (unlike other Acentrella/fg1); subimaginal vestige of pa- 
racercus develops in it with wastes. Cerci subequal $2 / 3$ of body length. Primary swimming setae well-developed: absent o 1-2 proximal segments; one or a few on each next segment; about 8 setae with pressed transverse bases on each middle segment; absent on several last segments.

Subimago. Cuticular COLORATION. Thoracic sclerites brown. Cuticle of legs light. Cuticle of abdominal terga I-VIII light brownish, tergum IX and sterna lighter. Wings light.

HyPodermal COLORATION. As in imago.

Imago, male. Head and thorax dark brown. Turban eyes nearly cylindrical, slightly widened apically, strongly divergent toward front and toward apex, so that distance between facetted surfaces nearly equal $1 / 2$ of facetted surface width (Figs 85-86); their color orange, upper portion of stem light. Legs pail; fore femur brownish, lighter toward apex. On fore leg femur 1.15 times longer than in larva; tibia 1.7 of femur length; tarsus longer than femur, ca. 1.6 of femur length. On middle and hind leg femur and tarsus have length as in larva; tibia 1.5 times longer than in larva and subimago. On middle and hind legs tarsus has 3 apical spines: $1^{\text {st }}+2^{\text {nd }}, 3^{\text {rd }}$ and $4^{\text {th }}$ tarsomeres are spine-bearing (as in Fig. 5) [see Acentrella/ fg2 (4)]. Fore wing has basal sclerites dark brown; veins light; pterostigma colorless, with several incomplete crossveins. Hind wings absent. Abdominal segments II-VI whitish, with darkened tracheal trunks. Segments VII-IX have terga dark-brown; sterna with dark brown margins and whitish median part. Segment X light. Gonostyli whitish. Penial bridge medially lacks sclerotized projection; gonovectes brown, slightly bent (Fig. 87). Styligeral muscle narrow (as in Fig. 3). Cerci whitish.

Imago, female. Head, thorax and abdomen ocher-yellow; mesonotum with narrow median brown line. Fore legs ocher, middle and hind legs lighter. On fore leg tarsus has 3 apical spines: tarsomeres $2^{\text {nd }}, 3^{\text {rd }}$ and $4^{\text {th }}$ are spine-bearing; on middle and hind legs tarsus also has 3 apical spines: $1^{\text {st }}+2^{\text {nd }}$, $3^{\text {rd }}$ and $4^{\text {th }}$ tarsomeres are spine-bearing (as in male) (as in Figs 4, 5) [see Acentrella/fg2 (4)].

Egg. Length about $0.1-0.15 \mathrm{~mm}$. Chorion with striation: entire surface consists of numerous thin longitudinal ridges separated by grooves.

Dimension. Fore wing length 3-4 $\mathrm{mm}$.

DISTRIBUTION. East of Asia: south of East Siberia and Russian Far East, Japan, Taiwan.

\section{C.1.1.4. Group sibiricum}

(Figs 14-17, 88-116, 121-122)

Systematic position: Acentrella/fg1—pm.Acentrella/fg2gr.sibiricum.

This group differs from most other Acentrella/fg1 (and most Turbanoculata in general) by loss of muscle in the $2^{\text {nd }}$ segment of labial palp (Fig. 101). Larval abdominal terga are short and wide, much wider than sterna, thus abdomen is strongly convex dorsally and flattened ventrally (Figs 14, 17); if spread abdominal tergum II on slide, distance between tergalii bases divided to length varies from 5 to 6 (among other Acentrella/fg1 it varies from 4 to 5 - Table 2). Hind wings absent.

SPECIES COMPOSITION: sibiricum [Pseudocloeon], diptera sp.n. [Acentrella] and scabriventris sp.n. [Acentrella].

\section{C.1.1.4-1. Acentrella/fg2 sibiricum [Pseudocloeon]} (Figs 14-17, 88-98, 121-122)

Systematic position: Acentrella/fg1-pm.Acentrella/fg2gr.sibiricum.

Original binomen: Pseudocloeon sibiricum Kazlauskas, 1963.

Subjective synonym: Acentrella glareosa Sroka \& Arnekliev, 2010, syn.n.

Possible binomina:

- Acenrella sibirica;

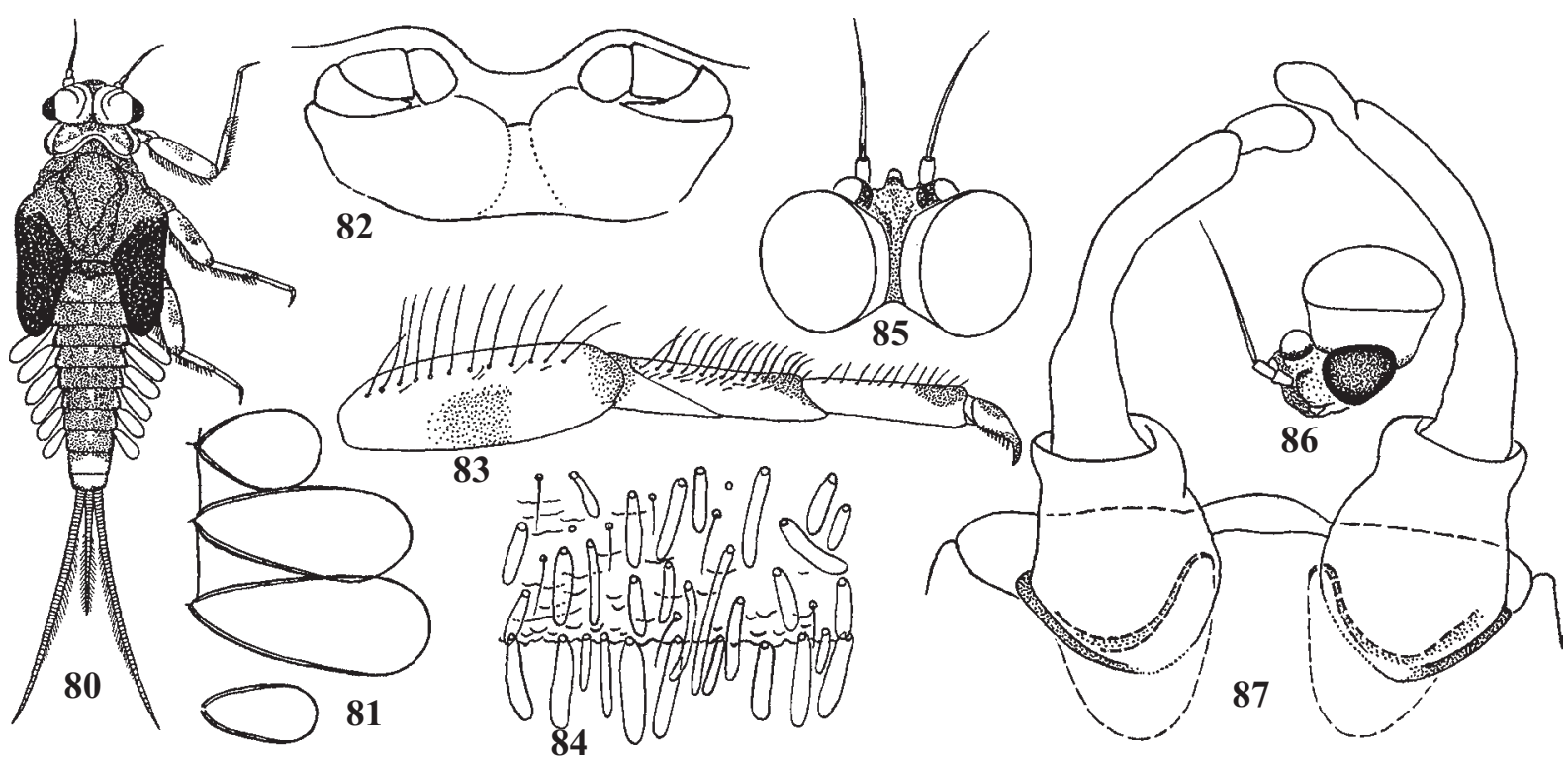

Figs 80-87. Acentrella/fg2 gnom [Pseudocloeon]: 80 - mature male lava, dorsal view; 81 - tergalii I-III and VII; 82 -buds of subimaginal gonostyli folded under larval cuticle; 83 - larval middle leg; 84 — posterior margin of larval abdominal tergum VI; 85 - head of male imago, lateral view; 86 - the same, dorsal view; 87 - genitals of male imago, ventral view (muscles not shown).

Рис. 80-87: Acentrella/fg2 gnom [Pseudocloeon]: 80 - зрелая личинка, дорсально; 81 - тергалии I-III и VII; 82 - зачатки субимагинальных гоностилей, сложенные под личиночной кутикулой; 83 - средняя нога личинки; 84 - задний край VI тергита брюшка личинки; 85 — голова самца имаго, латерально; 86 - то же, дорсально; 87 - гениталии самца имаго, вентрально (мышцы не показаны). 
- Baetis sibiricus;

- Baetis (Acentrella) sibiricus.

REFERENCES: Pseudocloeon sp. Nr.3: Sukackiene, 1962 (larva); Pseudocloeon sibiricum Kazlauskas, 1963 (larva); Baetis (Acentrella) sibiricus: Tshernova \& al., 1986 (imago, partim); Novikova \& Kluge, 1987; Kluge, 1995 (larva, holotypus); Kluge, 1997b (larva); Acentrella sibirica: Waltz \& McCafferty, 1987b; Acentrella glareosa Sroka \& Arnekliev, 2010 (larva). For the species wrongly identified as Pseudocloeon sibiricum by Kluge, 1980 and Tshernova et al., 1986 - see below, diptera [Acentrella].

MATERIAL. RUSSIA: Altaiskiy kray (= Altai territory): river Biya near Biysk, 23.IX.1937, coll. S. Levanidova: 1 larva. Altai republic: river Iogach near Iogach, 28.VIII.1987, coll. N. Kluge: 1 LS-I ${ }_{+}$; Gorno-Altaysk, 7.VIII.1987, coll. N. Kluge: 1 L-S-IO'. Irkutskaya oblast' (= Irkutsk province), river Elovka in Ust'-Uda, 3.VII.1959: larvae (including holotype). Primorskiy kray (= Primorye territory): river Ussuri in Bulyga-Fadeevo, 1-10.VIII.1980, coll. N. Kluge: 11 L-S-I $\sigma^{7}, 6$ L-S-I, 5 L-S $\sigma^{7}, 8$ L-S $\bigcirc$; river Barabashevka (= Mongugay) near natural reserve "Kedrovaya Pad", 5.VII.1963, coll. Nochvina: 1 larva; 29-30.VI.1980, coll. N. Kluge: 2 L-S-IO'. KAZAKHSTAN, East Kazakhstan, river Irtysh near Ust' Kamenogorsk, 5.IX.1957, coll. O. Martynova: 2 larvae. MONGOLIA: Ovorhangay, river Orhon-gol near Harhorin, 3-7.IX.1997, coll. N. Kluge: 21 L-S-IO’, 14 L-S-I+, 5 L-S $\sigma^{7}, 10$ L-S +80 larvae.

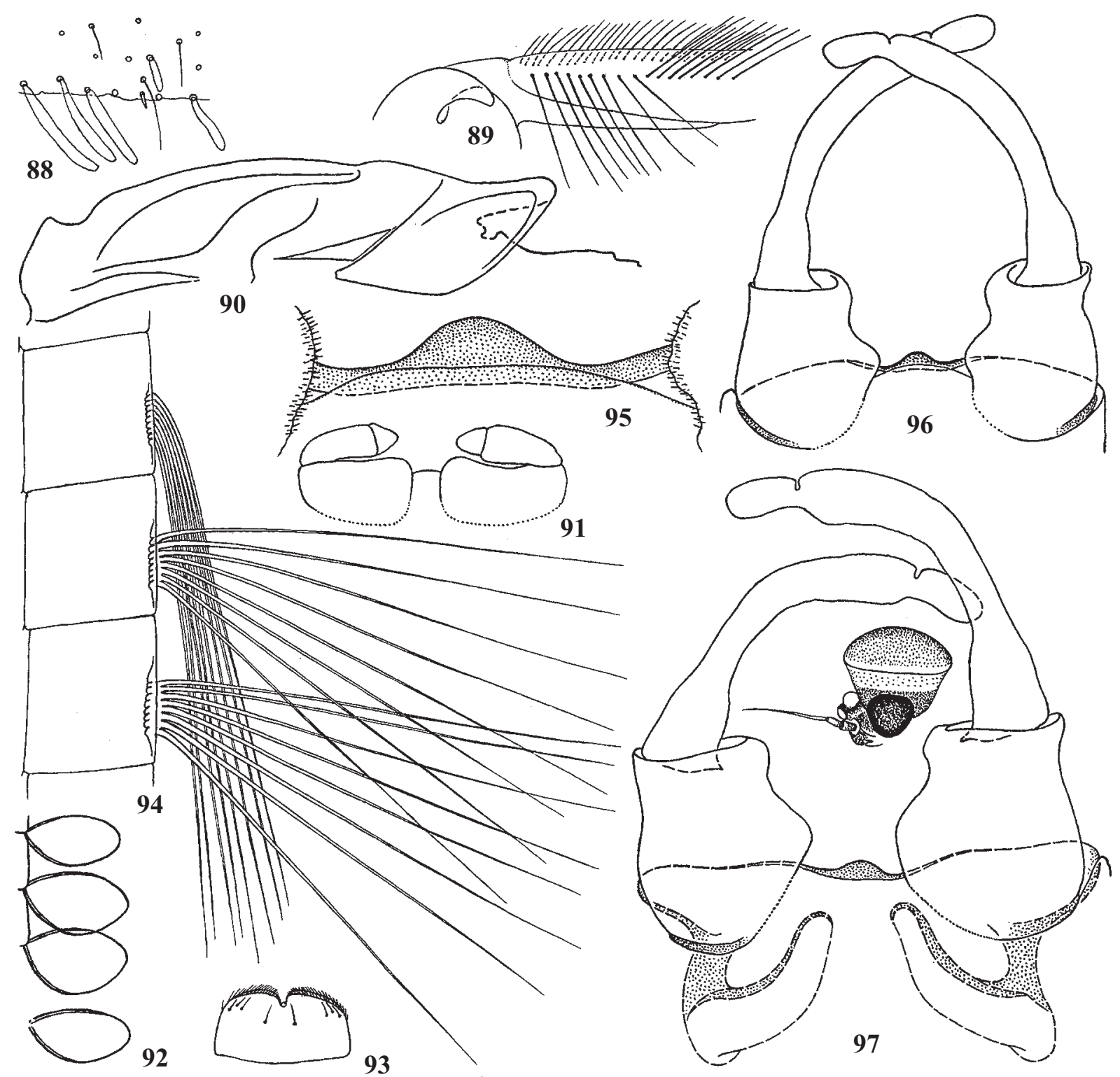

Figs 88-98. Acentrella/fg2 sibiricum [Pseudocloeon]: 88 - posterior margin of larval abdominal tergum VI (holotypus); 89 — proximal part of larval hind tibia (holotypus); 90 - imaginal mesonotum, lateral view; 91 - buds of subimaginal gonostyli folded under larval cuticle; 92 tergalii I-III and VII; 93 - labrum; 94 - middle segments of larval cercus; 95 - exposed part of penial bridge; 96 - genitals of male imago (gonovectes and muscles not shown); 97 - genitals of male imago, another specimen (muscles not shown); 98 - head of male imago, lateral view.

Рис. 88-98. Acentrella/fg2 sibiricum [Pseudocloeon]: 88 - задний край VI тергита брюшка личинки (голотип); 89- проксимальная часть задней голени личинки (голотип); 90 - имагинальный мезонотум, латерально; 91 - зачатки субимагинальных гоностилей, сложенные под личиночной кутикулой; 92 — тергалии I-III и VII; 93 - верхняя губа; 94 - средние членики церка личинки; 95 — открытая часть моста пениса; 96 - гениталии самца имаго, вентрально (гоновектисы и мышцы не показаны); 97 - гениталии самца имаго, другой экземпляр (мышцы не показаны); 98 - голова самца имаго, латерально. 
Ulaanbaatar (= Ulan Bator): river Tuul-gol above Ulaanbaatar near bridge Nalayh - Tereldzh, 9-10.VIII, 12.IX.1997, coll. N. Kluge: 5 larvae; river Tuul-gol below Ulaanbaatar near Sangino, 1112.VIII.1997, coll. N. Kluge: 4 larvae. KOREA: Ullung island, Tacha, 3.VIII.1983, coll. Y. Bae: 4 larvae. JAPAN: pref. Gifu, river Nagara, 18.X.1978, coll. A. Ponomarenko: 1 larva.

Larva. Cuticular COLORATION: Head and thorax can be nearly unicolor or have cuticle brown with diffusive lighter and darker areas; sometimes pronotum has dark sigilla (as in Fig. 133). Thoracic pleura dark, sterna colorless. Abdominal terga brown with diffusive light blanks; medioposterior sigilla darker than background, on anterior terga slightly transverse, on posterior terga round (as in Fig. 110); sterna at most part light. Femora light with diffusive brownish areas; tibiae and tarsi diffusively darkened apically. Cuticle of cerci uniformly light.

HyPODERMAL COLORATION: Hypoderm without contrasting markings

SHAPE AND SETATION: Body markedly widened. Frons somewhat projected above clypeus, without dens setae. Labrum short, length equal $1 / 2$ of width (Fig. 93). Mandibles not blade-like (as in Fig. 102). Labium as in Figs 100-101, with paraglossal muscle oblique and fan-like; $2^{\text {nd }}$ palpomere short, without muscle; $3^{\text {rd }}$ palpomere wide, rounded. Mesosternum and metasternum each with a pair of pointed conic subfurcal protuberances. Hind protoptera reduced to small vestiges (as in Fig. 125). Legs thick: femur width more than $1 / 3$ of femur length; tibia width about $0.15-0.18$ of tibia length. Femora of all legs have subequal length. On fore leg length of tibia subequal or less than length of femur; on middle leg tibia shorter and on hind leg shorter, about $0.7-0.8$ of femur length. Tarsus of middle and hind leg 0.5 of femur length; tarsus of fore leg longer, 0.6 of femur length. Patella occupies about $1 / 2$ of inner tibial margin. Setae forming the regular row of on external margin of femur dense and long, with length subequal to femur width; near apex of femur located densely and irregularly. Setae forming the regular row on dorsal margin of tibia [see Acentrella/fg1 (3)] long, with length exceeding tibia width. At least middle and hind tibiae have second (external) regular row of setae, whose length slightly shorter than tibia width. Tarsi of middle and hind legs also with 2 regular rows of setae. Claws with 6-10 denticles; subapical setae vestigial [Sroka \& Arnekliev, 2010: Figs 21, 22)]. Abdominal terga strongly widened: width of spread abdominal tergum II between tergalii bases 6 times exceeds its length. Abdominal terga smooth, with long bandlike translucent scales; hind margins of terga without denticles (Fig. 88). Paired sternal fields of dentate protuberances transverse, narrow, locate only laterad of medioposterior sigilla (as in Fig. 99). Tergalii of all pairs subequal, 2 times longer than tergum, with width exceeding tergum length (Fig. 92). Paracercus vestigial, one-segmented, subimaginal vestige of paracercus develops in it without wastes. Cerci subequal to body length. Primary swimming setae developed: absent on a dozen proximal segments; one or a few on each next segment; about 8-10 setae with pressed transverse bases on each middle segment (Fig. 94); absent on several last segments.

Subimago. Cuticular coloration. Thoracic sclerites brown. Cuticle of legs light, tarsi darkened. Cuticle of abdominal segments I-VIII light brownish; cuticle of segments IX-X contrastingly lighter, often colorless. Wings light.

HyPODERMal COLORATION. As in imago.

Imago, male. Head and thoracic sclerites dark brown. Turban eyes moderately wide (Fig. 98), orange. Fore leg has femur brownish, tibia yellowish with apex brownish, tarsus yellowish. Middle and hind legs have femur light brownish, darker in distal part, tibia and tarsus yellowish. On middle and hind legs tarsus has 3 apical spines: $1^{\text {st }}+2^{\text {nd }}, 3^{\text {rd }}$ and $4^{\text {th }}$ tarsomeres are spine-bearing (as in Fig. 5) [see Acentrella/ fg2 (4)]. Fore wing has basal sclerites brown; veins light; pterostigma colorless, with about 10 incomplete crossveins. Abdomen with all terga brown; sterna lighter, ocher, with brownish lateral margins. $1^{\text {st }}$ segment of gonostylus slightly narrowed toward apex, $2^{\text {nd }}$ segment widened toward apex, $3^{\text {rd }}$ segment not long, not curved; penial bridge medially with a prominent small roundish sclerotized projection; each gonovectis sharply bent, originates from lateral penial sclerotization by wide base (Figs 95-97). Styligeral muscle narrow (as in Fig. 3). Cerci yellowish-whitish.

Imago, female. Head, thorax, legs and abdomen ocher, lighter than in male. On fore leg tarsus has 3 apical spines: $2^{\text {nd }}$, $3^{\text {rd }}$ and $4^{\text {th }}$ tarsomeres are spine-bearing; on middle and hind legs tarsus also has 3 spines: $1^{\text {st }}+2^{\text {nd }}, 3^{\text {rd }}$ and $4^{\text {th }}$ are spinebearing (as in male) (as in Figs 4, 5) [see Acentrella/fg2 (4)]. tarsomeres

Egg. Length about $0.15 \mathrm{~mm}$. Surface without striation or reticulation, with fine irregular roughness only.

Dimension. Fore wing length $5 \mathrm{~mm}$.

DISTRIBUTION. Altai, East Siberia, Mongolia, Russian Far East, Korea, Japan.

\section{C.1.1.4-2. Acentrella/fg2 diptera sp.n. [Acentrella]} (Figs 99-112)

Systematic position: Acentrella/fg1—pm.Acentrella/fg2gr.sibiricum.

Original binomen: Acentrella diptera Kluge \& Novikova, sp.n.

Possible binomina:

- Acenrella diptera;

- Baetis dipterus;

- Baetis (Acentrella) dipterus.

REFERENCES: Pseudocloeon sibiricum: Kluge, 1980 (non Pseudocloeon sibiricum Kazlauskas, 1963) (larva, imago); Baetis (Acentrella) sibiricus: Tshernova \& al., 1986: Fig. 28 (imago).

MATERIAL. Holotype: L-S-IO', RUSSIA, Primorskiy kray (= Primorye Territory), Verhne-Ussuriyskiy (= Upper-Ussuri) research station of Biological Institute, 35 SW Chuguevka, 3.VIII.1980, coll. N. Kluge, specimen [XXX](13)80. Paratypes: RUSSIA: Taymyrskiy (Dolgano-Nenetskiy) avtonomnyy okrug (= Taymyr autonomous region), river Ekhilakh (left tributary of river Kotuy $30 \mathrm{~km}$ above mouth of river Medvezh'ya, 30.VII-2.VIII.1979, coll. N. Kluge: 2 L-S-IO', 1 L-S-I 9 , 1 L-S $\sigma^{7}, 1$ larva. Khabarovskiy kray (= Khabarovsk territory), near Obluch'e, basin of river Listvenichnaya, 28.VII.1976, coll. A. Mikheev \& N. Sinitshenkova: 1 larva; the same place, 30.VII-5.VIII.1984, coll. N. Kluge: 2 larvae. Primorskiy kray (= Primorye Territory): basin of river Bikin, river Bolshaya Svetlovodnaya (= Biamo), $40 \mathrm{~km}$ above mouth, 24.VII.1976, coll. V. Zherichin: 1 larva; near mouth of river Londo, 14.IX.1977, coll. V. Zherichin: 1 larva. The same locality as holotype (35 SW Chuguevka), 1-3.VIII.1980, coll. N. Kluge: 1 L-S-IO', 1 L-S-I, 5 larvae. Natural reserve "Kedrovaya Pad" and river Barabashevka (= Mangugay), 24.VI-10.VII.1980, coll. N. Kluge: 1 L-S-I O', 6 L-S$\mathrm{I}+, 6 \mathrm{~L}-\mathrm{S} \sigma^{7}, 1 \mathrm{~L}-\mathrm{S}+, 36$ larvae. Sikhote-Alin natural reserve, river Yasnaya, 8.VIII.1990, coll. N. Kluge: 1 L-S-IO'. Magadanskaya oblast' (= Magadan province), river Khasyn near Khasyn, 27.VII.1978, coll. V. Zherichin \& N. Sinitshenkova: 3 larvae.

Larva. Cuticular COLORATION: Head and thorax have cuticle brown with diffusive lighter and darker areas; sometimes pronotum has dark sigilla (as in Fig. 133). Thoracic pleura dark, sterna colorless. Abdominal terga brown with diffusive light blanks; medioposterior sigilla darker than background, on anterior terga slightly transverse, on posterior terga round (Fig. 110); sterna at most part light. Femora light with diffusive brownish areas; tibiae and tarsi diffusively darkened apically. Cuticle of cerci uniformly light. 


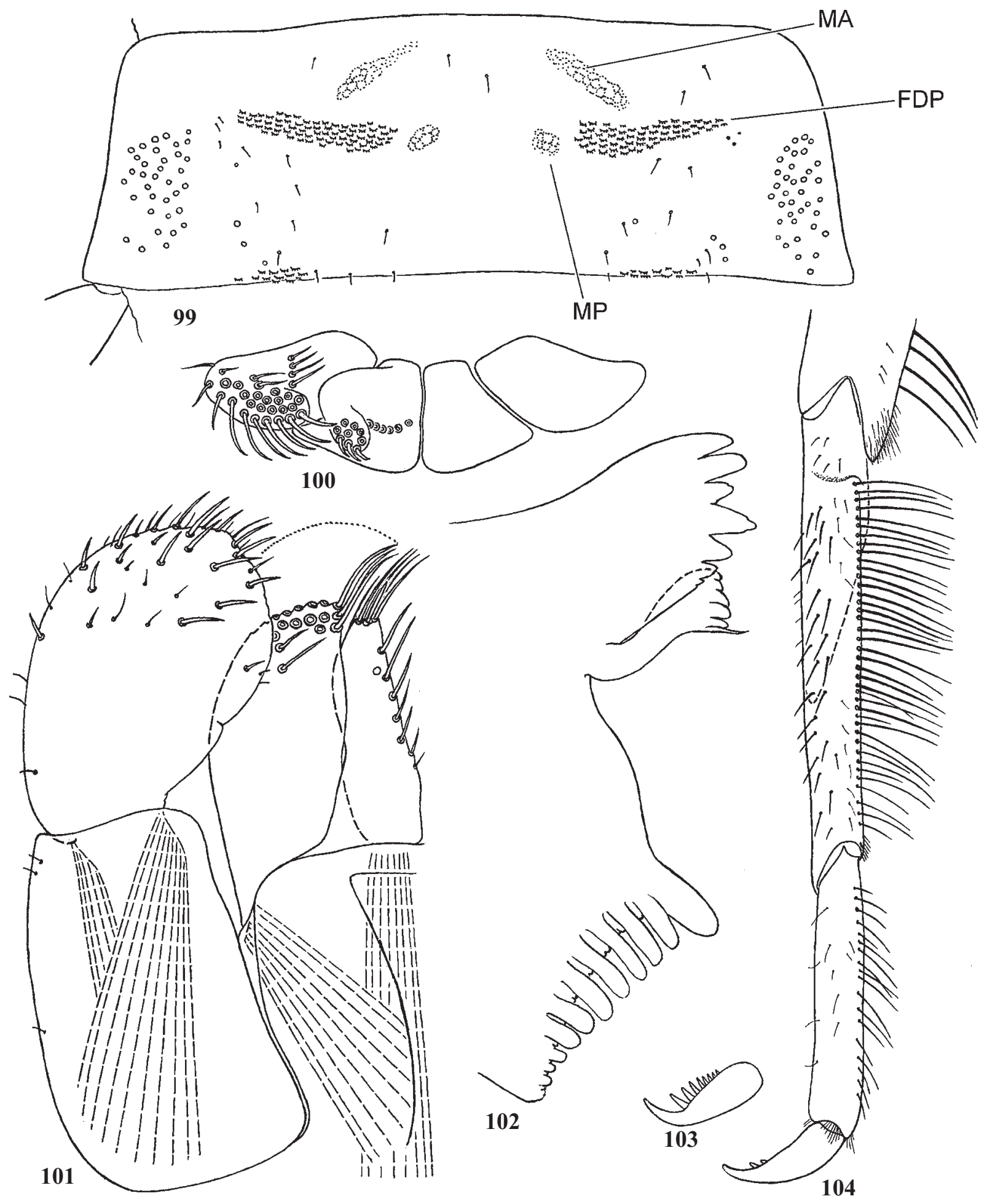

Figs 99-104. Acentrella/fg2 diptera sp.n. [Acentrella], larva: 99 — abdominal sternum VI (holotype); 100 — labium, apical view; 101 - half of labium, ventral view (muscles shown by interrupted lines); 102 - left mandible; 103 — claw; 104 - tibia and tarsus of right hind leg (holotype); FDP - field of dentate protuberances; MA — medioanterior sigillum; MP - medioposterior sigillum.

Pис. 99-104. Acentrella/fg2 diptera sp.n. [Acentrella], личинка: 99 — экзувий VI стернита брюшка (голотип); 100 — нижняя губа, апикально; 101 - половина нижней губы, вентрально (мышцы показаны прерывистыми линиями); 102 — левая мандибула; 103 коготок; 104 — голень и лапка правой задней ноги (голотип); FDP — поле зубчатых бугорков; MA — медиально-передняя сигилла; МР - медиально-задняя сигилла. 
HYPODERMAL COLORATION: Hypoderm without contrasting markings.

SHAPE AND SETATION: Body markedly widened. Frons somewhat projected above clypeus, without dens setae. Labrum has medium proportions, its length somewhat exceeds $1 / 2$ of width (Fig. 111). Mandibles not blade-like (Fig. 102). Labium with paraglossal muscle oblique and fan-like; $2^{\text {nd }}$ palpomere short, without muscle; $3^{\text {rd }}$ palpomere wide, rounded (Figs 100-101). Mesosternum and metasternum each with a pair of pointed conic subfurcal protuberances. Hind protoptera reduced to small vestiges (as in Fig. 125). Legs not as thick as in sibiricum $[P$.]: femur width 3.5 times less than femur length; tibia width about 0.16 of tibia length. Femora of all legs have subequal length. On fore leg length of tibia subequal to length of femur; on middle leg tibia shorter and on hind leg shorter, about 0.8 0.9 of femur length. Tarsus of middle and hind leg 0.5 of femur length; tarsus of fore leg longer, 0.7 of femur length. Tibia and tarsus not thick: tibia width about 0.13 of length. Patella occupies about $1 / 2$ of inner tibial margin. Setae forming the regular row of on external margin of femur dense and long, with length subequal to femur width; near apex of femur located densely and irregularly. Setae forming the regular row on dorsal margin of tibia [see Acentrella/fg1 (3)] long, with length exceeding tibia width. Second (external) row of setae absent (unlike sibiricum $[P$.$] ); on its place only irregularly$ located setae present (Fig. 104). Tarsus in proximal half has a regular row of setae similar to setae on tibia, but smaller (Fig.
104). Claws with 7-10 denticles; subapical setae vestigial. Abdominal terga strongly widened: width of spread abdominal tergum II between tergalii bases 5-6 times exceeds its length. Abdominal terga with long narrow translucent scales; hind margins of terga with sparse pointed spine-like denticles (Fig. 105) (unlike sibiricum $[P$.]). Paired sternal fields of denticulate protuberances compact, transverse, widely separated; on sterna II-VIII these fields locate only laterad of medioposterior sigilla, thus median space between fields is subequal to width of each field, and longitudinally each field includes 5-7 denticulate protuberances only (Fig. 99); on sternum IX (which has no medioposterior sigilla) space between fields a little less than width of each field, and longitudinally each field includes 7-10 denticulate protuberances (the same in sibiricum $[P$. $]$ and most other species, in contrast to scabriventris [Acentrella]). Tergalii not large, tergalii of all pairs subequal, 1.5-2 times longer than tergum, with width subequal to tergum length. Paracercus vestigial, one-segmented, subimaginal vestige of paracercus develops in it without wastes. Cerci subequal to body length. Primary swimming setae developed: absent on a dozen proximal segments; one or a few on each next segment; about 8-10 setae with pressed transverse bases on each middle segment (as in Fig. 94); absent on several last segments.

Subimago. Cuticular coloration. Thoracic sclerites brown. Cuticle of legs light brownish, with knees darker. Cuticle of abdomen light brownish. Wings light.

Hypodermal COLORATION. As in imago.

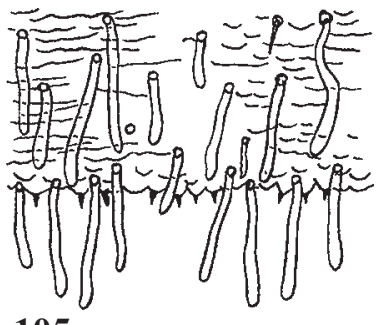

105

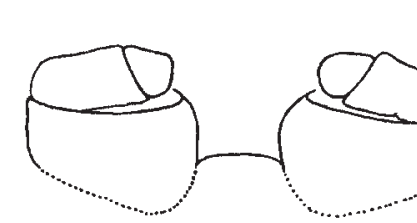
106

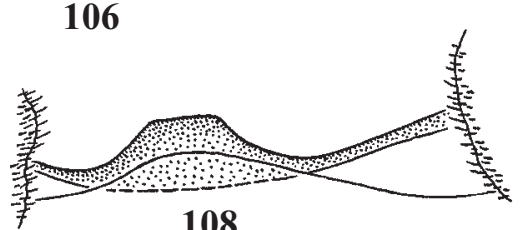

108
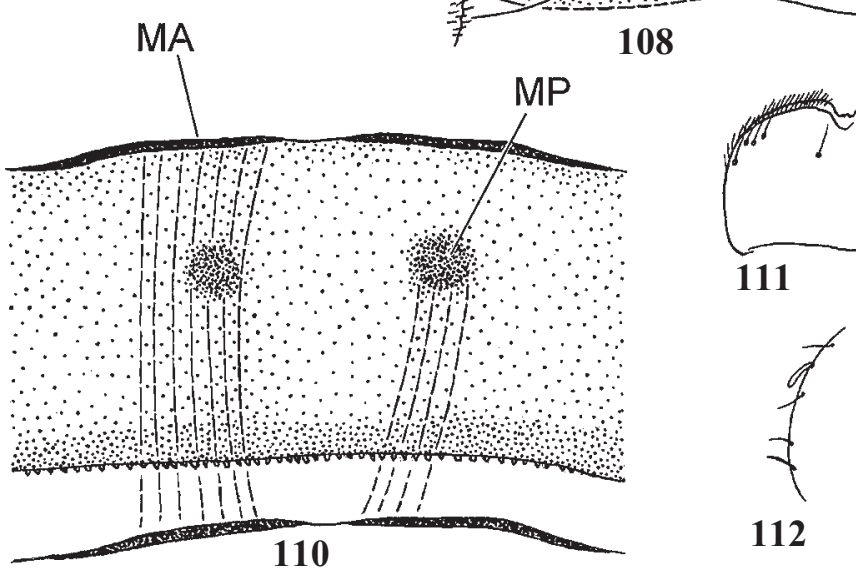

112

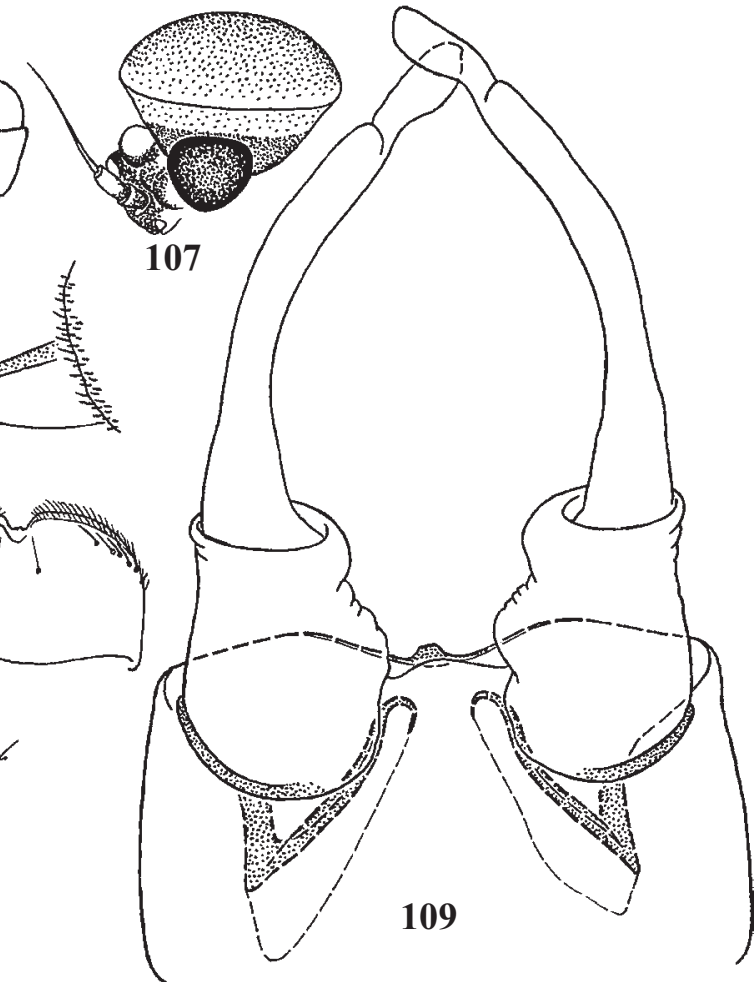

Figs 105-112. Acentrella/fg2 diptera sp.n. [Acentrella]: 105 — posterior margin of larval abdominal tergum VI; 106 — buds of subimaginal gonostyli folded under larval cuticle; 107 — head of male imago, lateral view; 108 — exposed part of penial bridge; 109 genitals of male imago (muscles not shown) (holotype); 110 - median part of larval tergum $\mathrm{V}$ and anterior margin of tergum VI (two muscles shown by interrupted lines); 111 - labrum; 112 - margin of tergalius; MA - medioanterior sigillum; MP - medioposterior sigillum.

Рис. 105-112. Acentrella/fg2 diptera sp.n. [Acentrella]; 105 - задний край VI тергита брюшка личинки; 106 - зачатки субимагинальных гоностилей, сложенные под личиночной кутикулой; 107 — голова самца имаго, латерально; 108 - открытая часть моста пениса; 109 - гениталии самца имаго, вентрально (мышцы не показаны) (голотип); 110 - медиальная часть V тергита и передний край VI тергита личинка (две мышцы показаны прерывистыми линиями); 111 — верхняя губа; 112 — край тергалии; МА - медиально-передняя сигилла; $\mathbf{M P}$ - медиально-задняя сигилла. 
Imago, male. Head and thoracic sclerites dark brown. Turban eyes moderately wide (Fig. 107), orange. Fore leg has femur brownish, tibia yellowish with apex brownish, tarsus yellowish. Middle and hind legs have femur light brownish, darker in distal part, tibia and tarsus yellowish. On fore leg femur 1.15 times longer than in larva; tibia 2 times longer than femur; tarsus nearly as long as tibia. On middle and hind leg femur and tarsus have length as in larva; tibia 1.2 times longer than in larva, so on hind leg tibia shorter, about 0.9 of middle tibia length. On middle and hind legs tarsus has 3 apical spines: $1^{\text {st }}+2^{\text {nd }}, 3^{\text {rd }}$ and $4^{\text {th }}$ tarsomeres are spine-bearing (as in Fig. 5) [see Acentrella/fg2 (4)]. Fore wing has basal sclerites brown; veins light; pterostigma colorless, with about 10 anatomizing crossveins. Abdomen with all terga brown; sterna lighter, ocher, with brownish lateral margins. Unistyligers relatively long, median side with shallow projections in middle and at apex. Apical $\left(3^{\text {rd }}\right)$ segment of gonostylus has moderate length (2.5 times shorter than $2^{\text {nd }}$ segment), longest at its outer side, thus apex is asymmetric in ventral or dorsal view; penial bridge medially with sharp narrow truncate projection; each gonovec- tis sharply bent, originates from lateral penial sclerotization by wide base (Fig. 109). Styligeral muscle narrow (as in Fig. 3). Cerci uniformly pale.

Imago, female. Head, thorax, legs and abdomen ocher, lighter than in male. On fore leg tarsus has 3 apical spines: $2^{\text {nd }}$, $3^{\text {rd }}$ and $4^{\text {th }}$ tarsomeres are spine-bearing; on middle and hind legs tarsus also has 3 apical spines: $1^{\text {st }}+2^{\text {nd }}, 3^{\text {rd }}$ and $4^{\text {th }}$ tarsomeres are spine-bearing (as in male) (as in Figs 4, 5) [see Acentrella/fg2 (4)].

Egg. Length about $0.13-0.15 \mathrm{~mm}$. Surface without striation or reticulation, with fine irregular roughness only.

Dimension. Fore wing length 5-6 mm.

COMPARISON. Formerly diptera $[A$.] was confused with sympatric species sibiricum $[P$.]; larva of diptera $[A$.] differs from sibiricum $[P$.] by absence of second regular setal row on middle and hind tibiae (Fig. 104); male imago differs by truncate shape of sclerotized median projection on penial bridge (Fig. 108); subimago differs by color of IX abdominal segment, whose cuticle is as dark as on other abdominal segments.

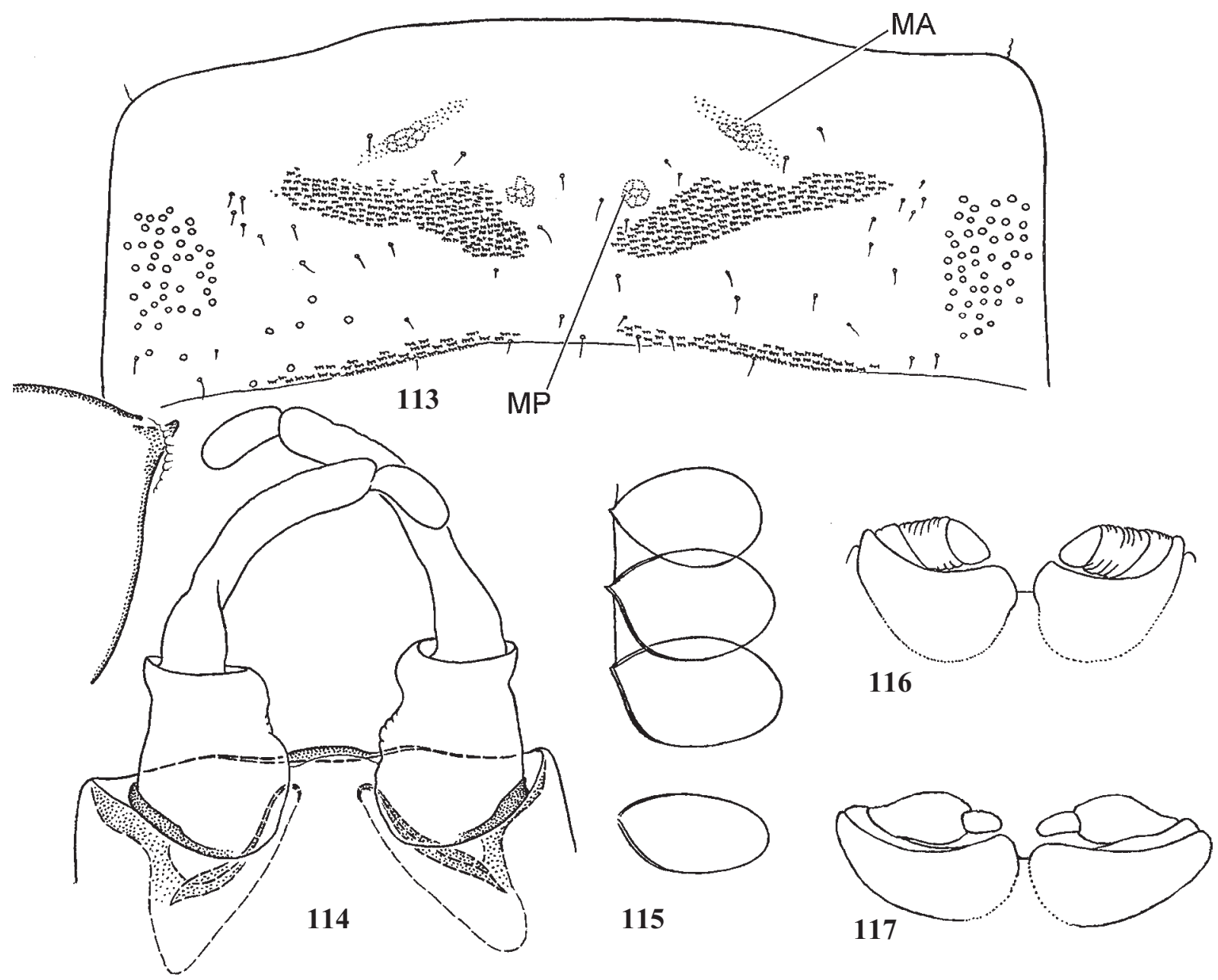

Figs 113-117. 113-116 - Acentrella/fg2 scabriventris sp.n. [Acentrella]: 113 — larval exuviae of abdominal sternum VI; $114-$ genitals of male imago, ventral view (muscles not shown) (holotype); 115 - tergalii I-III and VII; 116 - buds of subimaginal gonostyli folded under larval cuticle; 117 - Acentrella/fg2 sp. (China), the same; MA - medioanterior sigillum; MP — medioposterior sigillum.

Рис. 113-117. 113-116 — Acentrella/fg2 scabriventris sp.n. [Acentrella]: 113 — личиночный экзувий VI стернита брюшка; 114 гениталии самца имаго, вентрально (мышцы не показаны) (голотип); 115 - тергалии I-III и VII; 116 - зачатки субимагинальных гоностилей, сложенные под личиночной кутикулой; 117 - Acentrella/fg2 sp. (Китай), то же; МА — медиально-передняя сигилла; МP - медиально-задняя сигилла. 
New Siberian species diptera $[A$.] is closely related to the new Middle-Asian species scabriventris [A.]; larva of diptera $[A$.$] differs from scabriventris [A$.] by non-widened fields of denticulate protuberances on abdominal sterna; male imago differs by presence of a narrow prominent projection on penial bridge (Fig. 108)

New species diptera $[A$.] is similar to latum Müller-Liebenau, 1985 [Pseudocloeon], which is described as larvae from Taiwan; latum $[P$.] differs form diptera $[A$.] by less number of denticles on mola of left mandible [Müller-Liebenau, 1985: Fig. 4e], shorter denticles on claws [ibid.: Fig. 4k] and antennae with "basal segments covered by head capsule".

DISTRIBUTION. East Siberia and Russian Far East.

\section{C.1.1.4-3. Acentrella/fg2 scabriventris sp.n. [Acentrella]} (Figs 113-116)

Systematic position: Acentrella/fg1—pm.Acentrella/fg2gr.sibiricum.

Original binomen: Acentrella scabriventris Kluge \& Novikova, sp.n.

Possible binomina:

- Acenrella scabriventris;

- Baetis scabriventris;

- Baetis (Acentrella) scabriventris.

REFERENCES: Baetis (Acentrella) tonneri: Kluge, 1997b (non Braasch \& Soldán, 1983) (larva)

MATERIAL. Holotype: L-S-I $\sigma^{7}$, KYRGYZSTAN, river Talas near Talas, 31.V.1986, coll. N. Kluge, specimen [IV](20)86. Paratypes: The same locality, 28.V-11.VI.1986: 17 L-S-I ${ }^{7}$, 12 L-S-Iㅇ, 4 L-S $\sigma^{7}$ $2 \mathrm{~L}-\mathrm{S}+, 12$ larvae. TAJIKISTAN, river Yasman near Hait (tributary of Surkhob, N of Tojikobod), 13-16.VIII.1981, coll. N. Kluge: 1 L-SI $\sigma^{7}, 2$ L-S-I 9 , 1 L-S +1 larva. KAZAKHSTAN, South Kazakhstan, Karatau ridge, road Kentau-Chulakkurgan, near Achisay, 4-6.V.1988, coll. V. Lukhtanov: $1 \mathrm{I} / \mathrm{S} \mathrm{O}^{7}$

Larva. CUTICULAR COLORATION: Head and thorax have cuticle brown with diffusive lighter and darker areas; pronotum has dark sigilla (as in Fig. 133). Thoracic pleura dark, sterna colorless. Abdominal terga brown with diffusive light blanks; medioposterior sigilla darker than background, on anterior terga slightly transverse, on posterior terga round (as in Fig. 110); sterna at most part light. Femora light, with diffusive longitudinal brownish maculae; tibiae light, distal parts of tarsi dark. Cuticle of cerci uniformly brown.

HyPODERMAl COLORATION: Hypoderm without contrasting markings.

SHAPE AND SETATION: Body markedly widened. Frons somewhat projected above clypeus, without dens setae. Labrum has medium proportions, its length somewhat exceeds $1 / 2$ of width (as in Fig. 111). Mandibles not blade-like (as in Fig. 102). Labium as in Figs 100-101, with paraglossal muscle oblique and fan-like; $2^{\text {nd }}$ palpomere short, without muscle; $3^{\text {rd }}$ palpomere wide, rounded. Mesosternum and metasternum each with a pair of pointed conic subfurcal protuberances. Hind protoptera reduced to small vestiges (as in Fig. 125). Legs not as thick as in sibiricum $[P$.]: femur width 3.5 times less than femur length; tibia width about 0.16 of tibia length. Femora of all legs have subequal length. On fore leg length of tibia subequal to length of femur; on middle leg tibia shorter and on hind leg shorter, about $0.8-0.9$ of femur length. Tarsus of middle and hind leg 0.5 of femur length; tarsus of fore leg longer, 0.6 of femur length. Tibia and tarsus not thick: tibia width about 0.13 of length. Patella occupies about $1 / 2$ of inner tibial margin. Setae forming the regular row of on external margin of femur dense and long, with length subequal to femur width; near apex of femur located densely and irregularly. Setae forming the regular row on dorsal margin of tibia [see Acentrella/fg1 (3)] long, with length exceeding tibia width. Second (external) row of setae absent (unlike sibiricum $[P$.$] );$ on its place only irregularly located setae present (as in Fig. 104). Tarsus has a regular row of setae similar to setae on tibia. Claws with 7-10 denticles; subapical setae vestigial. Abdominal terga strongly widened: width of spread abdominal tergum II between tergalii bases 6 times exceeds its length. Abdominal terga with long narrow translucent scales; hind margins of terga with sparse pointed spine-like denticles (as in Fig. 105) (unlike sibiricum $[P$.$] ). Paired sternal fields of denticulate$ protuberances enlarged: on sterna II-VIII these fields are oblique, locate laterad and posteriad of medioposterior sigilla, thus median space between fields much less than width of each field; longitudinally each field includes up to 15 denticulate protuberances (Fig. 113); on sternum IX (which has no medioposterior sigilla) space between fields also much less than width of each field. Tergalii relatively large, tergalii of all pairs subequal, 2 times longer than tergum, with width exceeding tergum length (Fig. 115). Paracercus vestigial, one-segmented, subimaginal vestige of paracercus develops in it without wastes. Cerci subequal to body length. Primary swimming setae developed: absent on a dozen proximal segments; one or a few on each next segment; about 8 setae with pressed transverse bases on each middle segment (as in Fig. 94); absent on several last segments.

Subimago. Cuticular coloration. Thoracic sclerites brown. Cuticle of legs light brownish, with knees and tarsi darker. Cuticle of abdomen light brownish. Wings light.

Hypodermal COLORATION. As in imago.

Imago, male. Head and thoracic sclerites dark brown. Turban eyes moderately wide, orange. Fore leg has femur brownish, tibia yellowish with apex brownish, tarsus yellowish. Middle and hind legs have femur light brownish, darker in distal part, tibia and tarsus yellowish. On fore leg femur 1.1 times longer than in larva; tibia 1.7 times longer than femur; tarsus nearly as long as tibia. On middle and hind leg femur and tarsus have length as in larva; tibia 1.1 times longer than in larva, so on hind leg tibia shorter, about 0.9 of middle tibia length. On middle and hind legs tarsus has 3 apical spines: $1^{\text {st }}+2^{\text {nd }}, 3^{\text {rd }}$ and $4^{\text {th }}$ tarsomeres are spine-bearing (as in Fig. 5) [see Acentrella/fg2 (4)]. Fore wing has basal sclerites brown; veins light; pterostigma colorless, with about several incomplete crossveins. Abdomen with all terga brown; sterna lighter, ocher, with brownish lateral margins. Unistyligers relatively long, median side with shallow projections in middle and at apex. $1^{\text {st }}$ segment of gonostylus narrowed toward apex, $2^{\text {nd }}$ segment widened toward apex, $3^{\text {rd }}$ segment not long, not curved; penial bridge medially with a shallow wide sclerotized projection (in contrast to dipterus [B.] and sibiricum $[P]$.$) ; each gonovectis sharply bent, originates from lateral$ penial sclerotization by wide base (Fig. 114). Styligeral muscle narrow (as in Fig. 3). Cerci uniformly pale.

Imago, female. Head, thorax, legs and abdomen ocher, lighter than in male. On fore leg tarsus has 3 apical spines: $2^{\text {nd }}$, $3^{\text {rd }}$ and $4^{\text {th }}$ tarsomeres are spine-bearing; on middle and hind legs tarsus also has 3 apical spines: $1^{\text {st }}+2^{\text {nd }}, 3^{\text {rd }}$ and $4^{\text {th }}$ tarsomeres are spine-bearing (as in male) (as in Figs 4, 5) [seeAcentrella/fg2 (4)].

Egg. Length about $0.14-0.15 \mathrm{~mm}$. Surface without striation or reticulation, with fine irregular roughness only.

Dimension. Fore wing length 5-6 mm.

DISTRIBUTION. Middle Asia.

COMPARISON. The new Middle Asian species scabrivntris $[$ Acentrella] is closely related to the new Siberian species diptera [Acentrella]; larva of scabriventris [A.] differs from diptera $[A$. $]$ only by widened fields of denticulate protuberances on abdominal sterna (Fig. 113); male imago differs by absence of a prominent median projection on penial bridge (Fig. 114). 
Comments. Braasch and Soldán [1983] described from high mountains of Middle Asia the species, which they called Baetiella tonneri. Judging by figures, this species should belong not to Baetiella, but to Acentrella [Waltz \& McCafferty, 1987b; Kluge, 1997b]. According to the original description, tonneri [Baetiella] has only 3-5 denticles on each claw, while scabriventris [Acentrella] has 7-10 denticles. As far as we know, only one species of Acentrella occurs in the high Middle Asian mountains, so the description of Baetiella tonneri contains error either in morphological characters, or in location. Its type specimens are lost. The name Baetiella tonneri Braasch and Soldán, 1983 should be regarded as nomen dubium.

\section{C.1.1.5. Uncertain group: Acentrella/fg2 sp. C} (Fig. 117)

Systematic position: Acentrella/fg1—pm.Acentrella/fg2.

MATERIAL. 1 mature male larva with label: "CHINA, Yang Chi shidu Dashag Li Tang He Kou, S. 1991".

Larva. Similar to sibiricum [Pseudocloeon] by presence of a regular second row of long setae on hind tibiae; differs from sibiricum [Pseudocloeon] by multisegmented vestige of larval paracercus, in which subimaginal paracercus develops with wastes (Table 2).

Imago, male. Unknown. Judging by subimaginal parts developed in mature larva, on middle and hind legs tarsus has
3 apical spines: $1^{\text {st }}+2^{\text {nd }}, 3^{\text {rd }}$ and $4^{\text {th }}$ tarsomeres are spinebearing (as in Fig. 5). Subimaginal genital buds folded under larval cuticle have peculiar shape, with $2^{\text {nd }}$ segment thick and $3^{\text {rd }}$ segment long and narrow (Fig. 117). Styligeral muscle narrow (as in Fig. 3).

\section{C.1.2. Jubabaetis/g1 \\ (Figs 123-187, 189-206)}

Systematic position: Acentrella/fg1-Jubabaetis/g1.

Hierarchical typified name: Jubabaetis/g1 (incl. Tanzaniops) [g: Jubabaetis Müller-Liebenau, 1980, typus J. pescadori MüllerLiebenau, 1980 (design. orig.)].

Possible ranking names in non-phylogenetic classifications:

- genus Jubabaetis

- subgenus Jubabaetis in genus Acentrella;

- subgenus Jubabaetis in genus Baetis.

This holophyletic taxon is circumscribed here for the first time. It is characterized by a unique autapomorphy and consists of species formerly placed to the African genus Tanzaniops and the Oriental genera Liebebiella, Jubabaetis and Platybaetis.

Autapomorphy.

(1) Flat projections, forming a row on mola of left mandible, are very small and petiolate; they begin at a distance from the distal molar projection, so that several small pointed denticles locate between them and the distal molar projection (Figs 136, 154, 168, 193, 202). In other Acentrella/fg1 flat

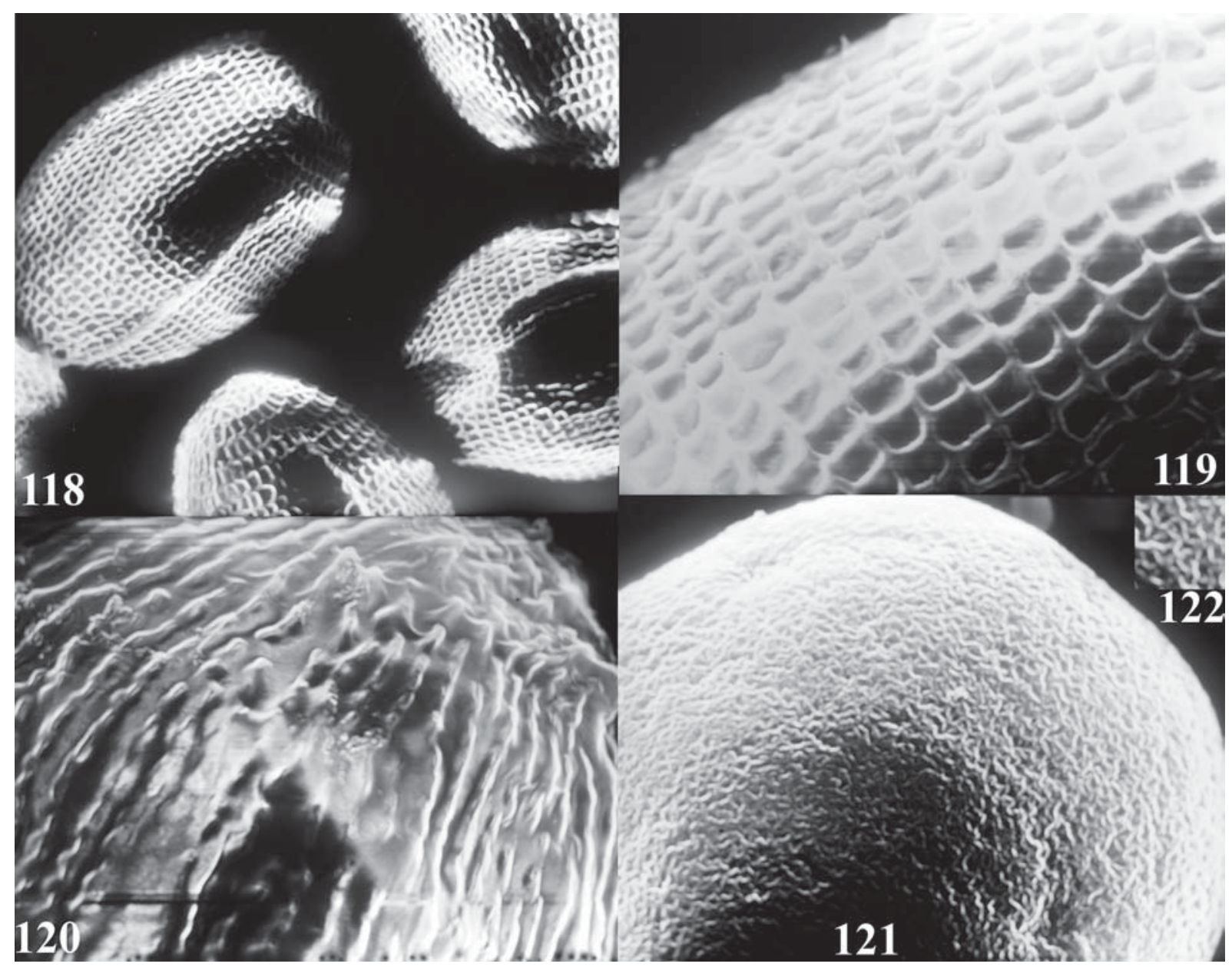

Figs 118-122. Eggs: 118-119 - chantauensis [Baetis]; 120 - inexpectatum [Pseudocloeon]; 121 - sibiricum [Pseudocloeon]; 122 — the same, enlarged fragment.

Рис. 118-122. Яйца: 118-119 — chantauensis [Baetis]; 120 — inexpectatum [Pseudocloeon];121 — sibiricum [Pseudocloeon]; 122 — то же, увеличенный фрагмент. 
denticles, forming a row on mola of left mandible, are longer than $1 / 2$ of the distal molar projection and begin close to it (Fig. 102).

\section{Characters of unclear phylogenetic status.}

(2) Fore tarsus of female imago and subimago has 2 apical spines: $2^{\text {nd }}$ and $3^{\text {rd }}$ tarsomeres are spine-bearing; $4^{\text {th }}$ tarsomere (penultimate, with stretched apical-ventral angle) lacks apicalventral spine. Initially, tarsus of middle and hind leg of both sexes retains 3 apical spines, i.e. $4^{\text {th }}$ tarsomere is spine-bearing, as in the plesiomorphon Acentrella/fg2 [see Acentrella/fg1 (10)]; this occurs in Tanzaniops, Jubabaetis/g3 and plesiomorphon Liebebiella. In Platybaetis tarsus of middle and hind leg of both sexes has only 2 apical spines (Fig. 185), as on fore leg of female [see below, Platybaetis (4)].

(3) Hind wings are always absent [see Acentrella/fg1 (7)].

(4) Larval frons, being projected above clypeus [see Acentrella/fg1 (2)], can bear peculiar setae, which are very dense, short, fine, colorless and curved dorsally-backward. In Jubabaetis/g3 these setae are enlarged [see below, Jubabaetis/g3 (2)]. In Tanzaniops and some species of the plesiomorphon Liebebiella (e.g., verum [P.], bispinosa $[A$.] and cylindroculata $[A$.$] ) these setae are smaller and poorly$ visible (Fig. 124). In some other species of Liebebiella (e.g., proximum [Pseudocloeon] and undescribed species from Philippines) these setae are absent. In Platybaetis frons is not projected above clypeus and these setae are absent.

DISTRIBUTION. Oriental and Ethiopian regions.

COMPOSITION. Jubabaetis/g1 is divided into African taxon Tanzaniops and Asian taxon Jubabaetis/g2.

\section{C.1.2.1. Tanzaniops/g(1), or Tanzaniops} (Figs 123-140, 170) iops

Systematic position: Acentrella/fg1—Jubabaetis/g1—Tanzan-

Hierarchical typified name: Tanzaniops/g1 [g: Tanzaniops McCafferty \& Barber-James 2005, typus Tanzaniella spinosa Gillies, 1991 (design. orig.) (syn. obj.: Tanzaniella Gillies, 1991 nom. praeocc., non Tanzaniella Hoffman, 1977)].

Possible ranking names in non-phylogenetic classifications:

— genus Tanzaniops;

- subgenus Tanzaniops in genus Jubabaetis;

- subgenus Tanzaniops in genus Acentrella;

- subgenus Tanzaniops in genus Baetis.

REFERENCES: genus Tanzaniella Gillies, 1991 (larva and imago); genus Tanzaniops McCafferty \& Barber-James, 2005.

Autapomorphies.

(1) Penial bridge has wide semicircular median incision (Figs. 132, 140). This character is known for spinosa [Tanzaniella] and lunamontana [Acentrella (Tanzaniops)], while genital structure of gorillora [Tanzaniella] is unknown.

(2) Paraglossal muscle of labium is longitudinal and parallel to the glossal muscle (Fig. 128) (unlike other Turbanoculata, whose paraglossal muscle is oblique and overlaps glossal muscle ventrally). This character is known for lunamontana [Acentrella], while for other species of Tanzaniops labial musculature is not described.

Plesiomorphy. Unlike Jubabaetis/g2, larval tarsus has no long subapical seta.

DISTRIBUTION. Ethiopian Region.

SPECIES COMPOSITION: spinosa Gillies, 1991 [Tanzaniella], gorillora McCafferty, 2002 [Tanzaniella] (= Baetis sp. CBB: Gose, 1964) and lunamontana sp.n. [Acentrella (Tanzaniops)]. Among them, two species are examined.

\section{C.1.2.1-1. Tanzaniops/g(1) lunamontana sp.n. [Acentrella (Tanzaniops)]}

(Figs 123-139, 170) iops.

Systematic position: Acentrella/fg1-Jubabaetis/g1-Tanzan-

Original binomen: Acentrella (Tanzaniops) lunamintana Kluge

\& Novikova, sp.n.

Possible binomina:

- Tanzaniops lunamintana

- Jubabaetis (Tanzaniops) lunamintanus

- Acentrella (Tanzaniops) lunamintana

- Acentrella (Jubabaetis) lunamintana:

- Baetis (Tanzaniops) lunamintanus;

- Baetis (Jubabaetis) lunamintanus:

- Baetis (Acentrella) lunamintanus.

MATERIAL. Holotype: L-S-I $\sigma^{7}$, UGANDA, Kasese district, Rwenzori mountains, river Ruboni (tributary of river Mubuku), 31.VII.2007, coll. N. Kluge, specimen [XIX] (15). Paratypes: The same locality, 28.VII-6.VIII.2007, coll. N. Kluge: 7 L-S-IO', 5 L-S $\sigma^{7}$, $2 \mathrm{~L}-\mathrm{S}_{+}, 1 \mathrm{~S}+, 52$ larvae. River Ibanda (tributary of river Mubuku), 1.VIII.2007, coll. N. Kluge: 3 larvae. Kilembe, 14-20.VIII.2007, coll. N. Kluge: 7 larvae. River Nyamagasan near Kiburara, 8-13.VIII.2007, coll. N. Kluge: 1 larva. Bundibugyo district, Rwenzori mountains, Bundibugyo, 23.VIII.2007, coll. N. Kluge: 13 larvae. Kanungu district, river Munyaga near Bwindi, 21-25.VII.2007, coll. N. Kluge: 15 larvae. Kapchorwa district, mount Elgon, Sipi Falls, 25-31.VIII.2007, coll. N. Kluge: 2 L-S +14 larvae.

Larva. Cuticular COlORATION: Head and thorax have cuticle brown with lighter and darker areas; pronotum has dark sigilla (Fig. 133). Thoracic pleura dark, sterna colorless. Abdominal terga brown with diffusive light blanks and dark medioposterior sigilla, which on most terga are strongly transverse (Fig. 134), and only on posteriormost terga roundish; sterna at most part light. Femora have characteristic color pattern (Figs 138, 139); tibiae and tarsi dark. Cuticle of cerci uniformly brown.

HyPODERMAL COLORATION: Abdomen of mature larva has characteristic hypodermal color as in imago (see below), which can be visible through cuticle.

SHAPE AND SETATION: Frons somewhat projected above clypeus, with fine, short, colorless, dens setae directed dorsally and posteriorly (Fig. 124) (being small and light, these setae are poorly visible). Scapus of antenna sharply asymmetric, with median side strongly expanded (Fig. 123). Labrum widened apically; medio-basal area, to which fronto-labral muscle attached, enlarged and rugose (Fig. 127). Mandibles blade-like (Fig. 136-137). Labium has mentum elongated, with long distance between bases of palps and bases of paraglossae; paraglossal muscle longitudinal and parallel to glossal muscle (Fig. 128) (unlike other Turbanoculata, whose mentum is shorter, with paraglossal muscle oblique and overlapping glossal muscle ventrally - compare with Fig. 39); $2^{\text {nd }}$ palpomere long, with muscle; $3^{\text {rd }}$ palpomere small, brownish (Fig. 128). Pronotum narrower than in other Acentrella/fg1: its width at posterior margin 2 times or less than length in middle. Mesosternum and metasternum each has a pair of conic subfurcal protuberances. Hind protoptera have a form of small vestiges (Figs 125-126). Legs long and slender (Figs 138-139). Femora of all legs have subequal length. Femur width about $1 / 4$ of femur length. Hind tibia has length subequal to femur, tibia width about 0.12 of tibia length. Fore and middle tibiae 1.2 times longer than femur, tibia width $0.08-0.09$ of tibia length. Tarsus of hind leg about 3 times shorter than tibia; tarsus of middle leg longer and tarsus of fore leg the longest, 1.3 times longer than hind tarsus. Patella occupies about $1 / 2$ of inner tibial margin, or less. Setae forming the regular row on external margin of femur have length subequal to femur width. Setae forming the regular row on dorsal margin of tibia [see Acentrella/fg1 (3)] long, about 1.5 times exceeding 


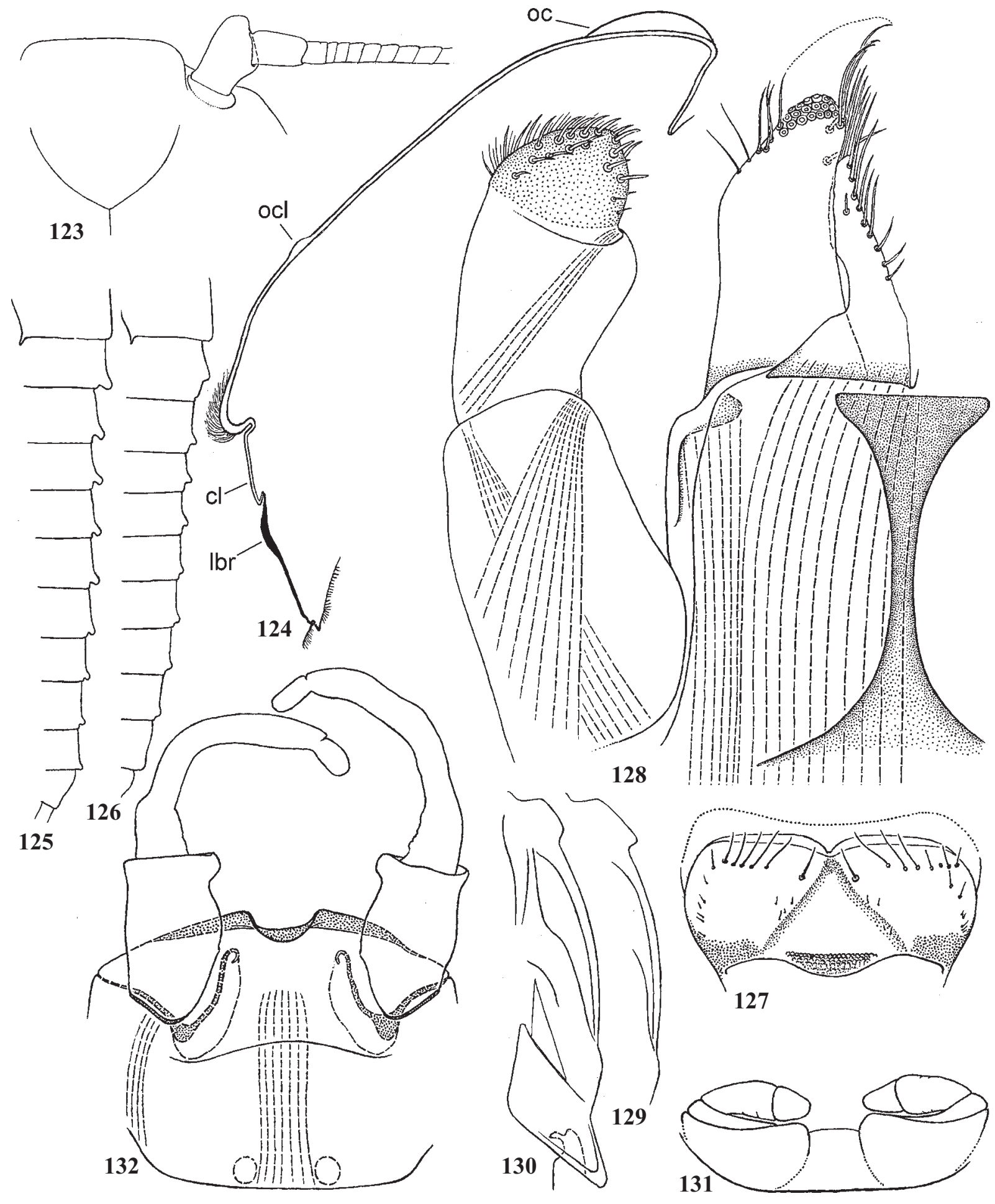

Figs 123-132. Tanzaniops/g1 lunamontana sp.n. [Acentrella (Tanzaniops)]: 123 — larval frons and base of right antenna; 124 - median longitudinal section through larval head, to show projected fore margin of frons with dense curved setae; 125 — metanotum and abdominal terga, lateral view (specimen from Bwindi); 126 - the same, specimen from Rwenzori; 127 - labrum (holotype); 128 — half of labium, ventral view (muscles shown by interrupted lines); 129-130 - imaginal mesonotum, lateral view; 131 - buds of subimaginal gonostyli folded under larval cuticle; 132 - genitals of male imago, ventral view (gonostylar muscles and right gonovectal muscle not shown; for explanation see Fig. 3) (holotype).

Pис. 123-132. Tanzaniops/g1 lunamontana sp.n. [Acentrella (Tanzaniops)]: 123 — лоб и основание правой антенны личинки; $124-$ медиальный продольный срез головы личинки, показывающий выступающий передний край лба с густыми изогнутыми щетинками; 125 - метанотум и тергиты брюшка, латерально (экземпляр из Bwindi); 126 - то же, экземпляр из Rwenzori; 127 - верхняя губа (голотип); 128 - половина нижней губы, вентрально (мышцы показаны прерывистыми линиями); 129-130 — имагинальный мезонотум, латерально; 131 - зачатки субимагинальных гоностилей, сложенные под личиночной кутикулой; 132 — гениталии самца имаго, вентрально (гоностилярные мышцы и мышца левого гоновектиса не показаны; объяснение на рис. 3) (голотип). 
tibia width; second (external) row of setae absent. Setae forming the row on dorsal margin of tarsus much smaller. Claw has 6-8 denticles and 2 well developed subapical setae. Abdominal terga slightly widened: width of spread abdominal tergum II between tergalii bases 3.5-4.5 times exceeds its length. Each tergum IIX has a small median protuberance on hind margin (Fig. 126); in specimens from Bwindi these protuberances especially prominent (Fig. 125). Abdominal terga without scales, hind margins of terga with cleft denticles (Fig.134). On abdominal sterna II-

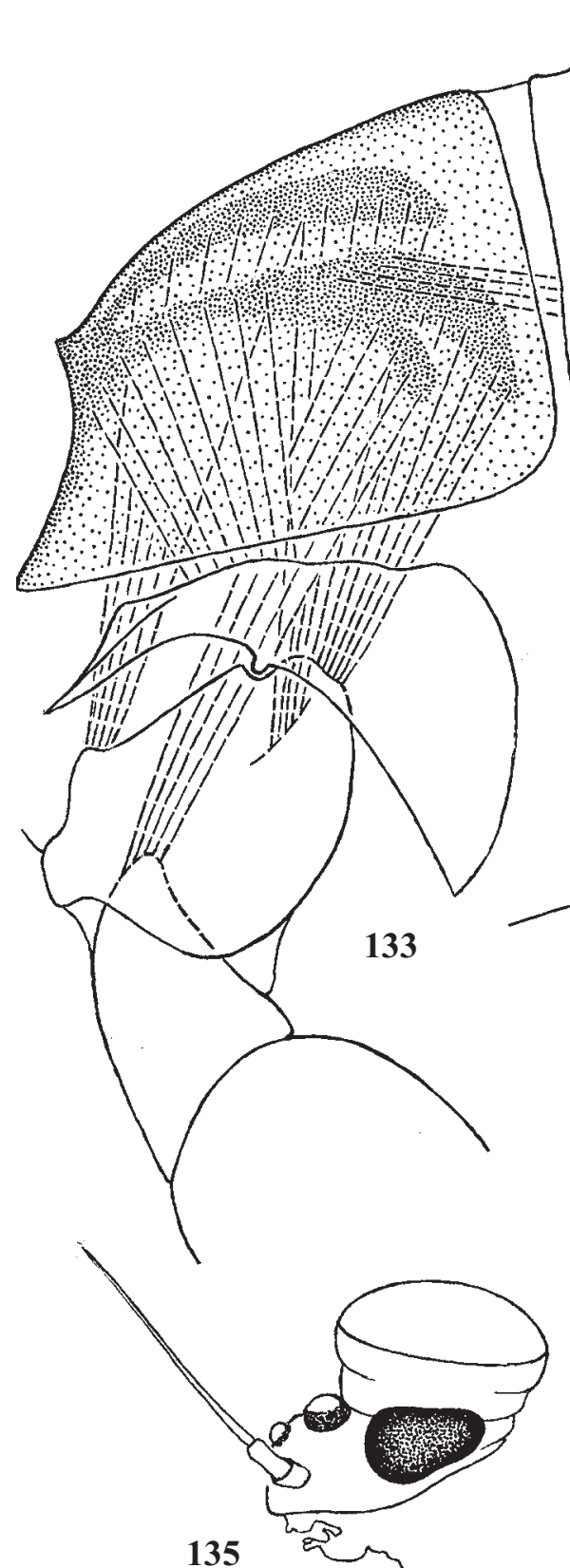

135

Figs 133-137. Tanzaniops/g1 lunamontana sp.n. [Acentrella (Tanzan pronotum shown by dots; muscles attached to sigilla of pronotum shown by (other muscles not shown); 134 _ medion of larval tergum V and anterior margin of tergum VI (two muscles shown by interrupted lines); 135 - head of male imago, lateral view (holotype); 136-137 — left and right mandibles; MA - medioanterior sigillum; MP - medioposterior sigillum.

Рис. 133-137. Tanzaniops/g1 lunamontana sp.n. [Acentrella (Tanzaniops)]: 133 — переднегрудь личинки, латерально; пигментаця пронотума показана пунктировкой; мышцы, подходящие к сигиллам пронотума, показаны прерывистыми линиями (прочие мышцы не показаны); 134 - медиальная часть V тергита и передний край VI тергита личинка (две мышцы показаны прерывистыми линиями); 135 - голова самца имаго, латерально (голотип); 136-137 - левая и правая мандибулы; МА — медиально-передняя сигилла; МР - медиально-задняя сигилла.

IX paired fields of dentate protuberances transverse, narrow, locate only laterad of medioposterior sigillum (as in Fig. 99). Tergalii elongate and asymmetric. Vestige of paracercus short and one-segmented, subimaginal vestige of paracercus develops in it without wastes. Cerci subequal to body length; primary swimming setae absent, but vestiges of their bases retained on middle segments.

Subimago. Cuticular COlORATION. Thoracic sclerites brown. Femora light brownish, with brown lines along inner

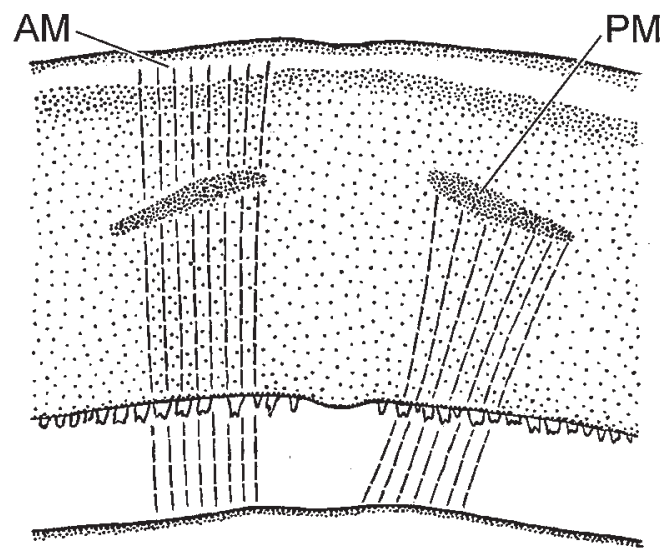

134

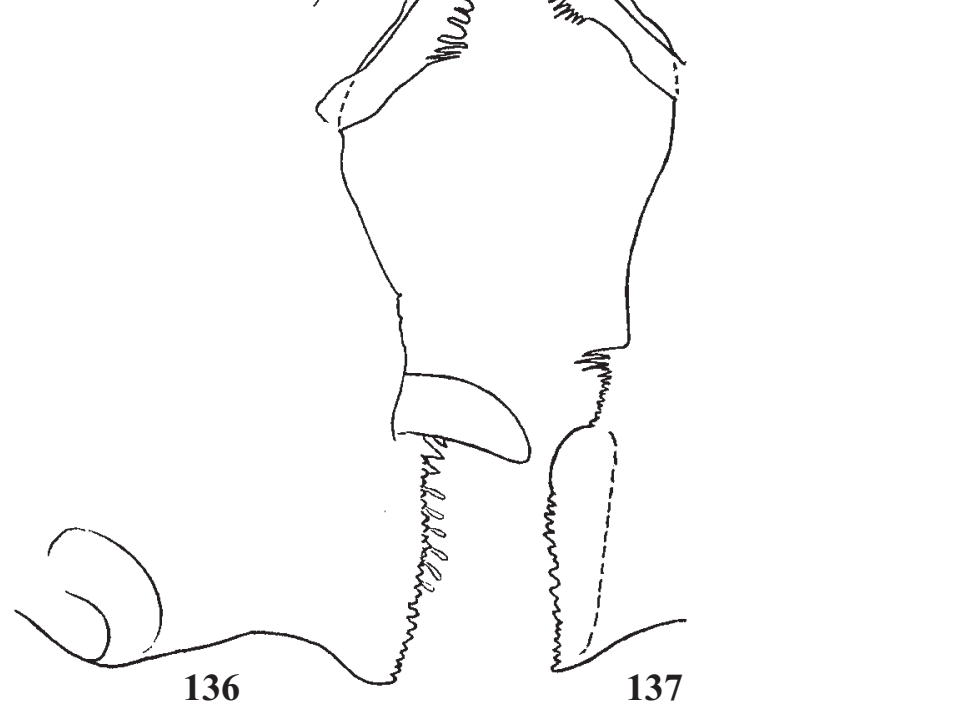


and outer margins and diffusive longitudinal brown macula near apex. Cuticle of abdomen light brownish. Wings light.

Hypodermal COLORATION. As in imago.

Imago, male. Head and thorax brown. Turban eyes low and wide (Fig. 135); facetted surfaces elliptic, longitudinal; facetted surfaces yellow or orange, side surfaces whitish. On fore leg femur and patella uniformly brown; tibia and tarsus light, apex of tibia and base of tarsus darkened. On middle and hind legs femur uniformly brown, except apex; apex of femur, whole tibia and tarsus light. On fore leg femur has the same length as in larva; tibia 1.6 of femur length; tarsus shorter than femur. On middle and hind leg length of femur, tibia and tarsus as in larva: their femora equal; on hind leg tibia equal to femur; on middle leg tibia longer than femur. On middle and hind legs tarsus has 3 apical spines: $1^{\text {st }}+2^{\text {nd }}, 3^{\text {rd }}$ and $4^{\text {th }}$ tarsomeres are spine-bearing (as in Fig. 5) [see Jubabaetis/g1 (2)]. Fore wing has basal sclerites dark brown; veins light brownish; pterostigma colorless, with 5-7 crossveins. Abdominal terga and sterna light brownish; each tergum II-VIII with a median transverse brown macula, which widened toward posterior margin; articulated membranes between terga light. Styliger and $1^{\text {st }}$ segments of gonostyli light brownish, $2^{\text {nd }}-3^{\text {rd }}$ segments of gonostyli colorless. Each unistyliger elongate, with median side convex, inner-distal margin projected; penial bridge light brownish, with semicircular incision medially; gonovectes brown, thick and short; styligeral muscle narrow (Fig. 132). Cerci uniformly light.

Imago, female. Head and thorax ocher-brown, lighter than in male. Color of legs as in male. On fore leg tarsus has 2 spines: $2^{\text {nd }}$ and $3^{\text {rd }}$ tarsomeres are spine-bearing, while $4^{\text {th }}$ tarsomere (penultimate, with stretched apical-ventral angle) lacks apical-ventral spine; on middle and hind legs tarsus has 3 apical spines: $1^{\text {st }}+2^{\text {nd }}, 3^{\text {rd }}$ and $4^{\text {th }}$ tarsomeres are spine-bearing (as in male) (as in Fig. 5) [see Jubabaetis/g1 (2)]. Abdomen ocher, with contrasting brown maculae similar to that of male.

Egg. Length about $0.14-0.16 \mathrm{~mm}$.

Dimension. Fore wing length 5-6 mm.

COMPARISON. Formerly, two species of Tanzaniops were described - spinosa Gillies, 1991 [Tanzaniella] and gorillora McCafferty, 2002 [Tanzaniella] (= Baetis sp. CBB: Gose, 1964). Larva of the new species differs from spinosa [Tanzaniella] by presence of the usual paired row of setae on dorsal surface of labium (while in spinosa [T.] there is a single pair of setae - Gillies, 1991: Fig. 9) and by longer $3^{\text {rd }}$ segment of labial palp. Imago of the new species differs from spinosa $[T$.] by characteristic brown maculae on abdominal terga. Larva of the new species differs from gorillora $[T$.] by row of long setae occupying whole length of hind tibia, by presence of subapical setae on claws of all legs and by onesegmented paracercus.

\section{C.1.2.1-2. Tanzaniops/g(1) spinosa [Tanzaniella]}

(Fig. 140) iops.

Systematic position: Acentrella/fg1—Jubabaetis/g1-Tanzan-

Original binomen: Tanzaniella spinosa Gillies, 1991.

Possible binomina:

- Tanzaniops spinosa;

- Jubabaetis (Tanzaniops) spinosa;

- Acentrella (Tanzaniops) spinosa;

- Acentrella (Jubabaetis) spinosa;

- Baetis (Tanzaniops) spinosus;

- Baetis (Jubabaetis) spinosus;

- Baetis (Acentrella) spinosus.

REFERENCES: Tanzaniella spinosa Gillies, 1991 (larva, imago); Tanzaniops spinosa: McCafferty \& Barber-James, 2005.

MATERIAL. TANZANIA, Amani, 11.XII.1961, coll. M.T. Gillies: $4 \mathrm{IO}^{\top}$ (paratypes, colorless).

Comments. This species was described as male and female imagoes and larvae [Gillies, 1991]. More detailed figure of its genitals, based on paratype, is given here (Fig. 140).

\section{C.1.2.2. Jubabaetis/g2}

(Figs 141-187, 189-206) etis/g2.

Systematic position: Acentrella/fg1—Jubabaetis/g1—JubabaS/g2.

Hierarchical typified name: Jubabaetis/g2 (sine Tanzaniops; incl. Liebebiella, Platybaetis).

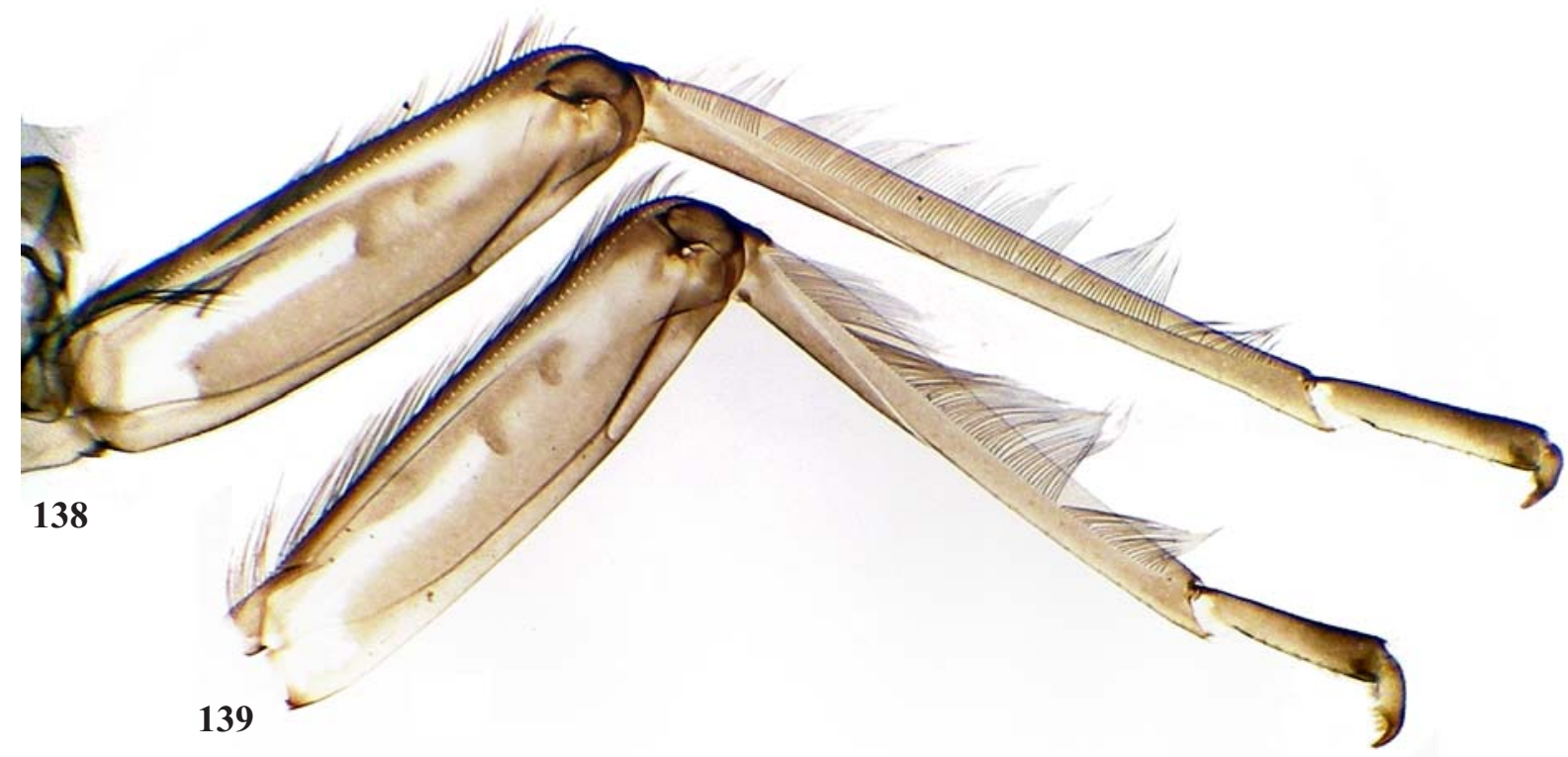

Figs 138-139. Tanzaniops/g1 lunamontana sp.n. [Acentrella (Tanzaniops)]. Exuviae of larval fore and hind legs (holotype).

Рис. 138-139. Tanzaniops/g1 lunamontana sp.n. [Acentrella (Tanzaniops)]. Экзувии передней и средней ног личинки (голотип). 


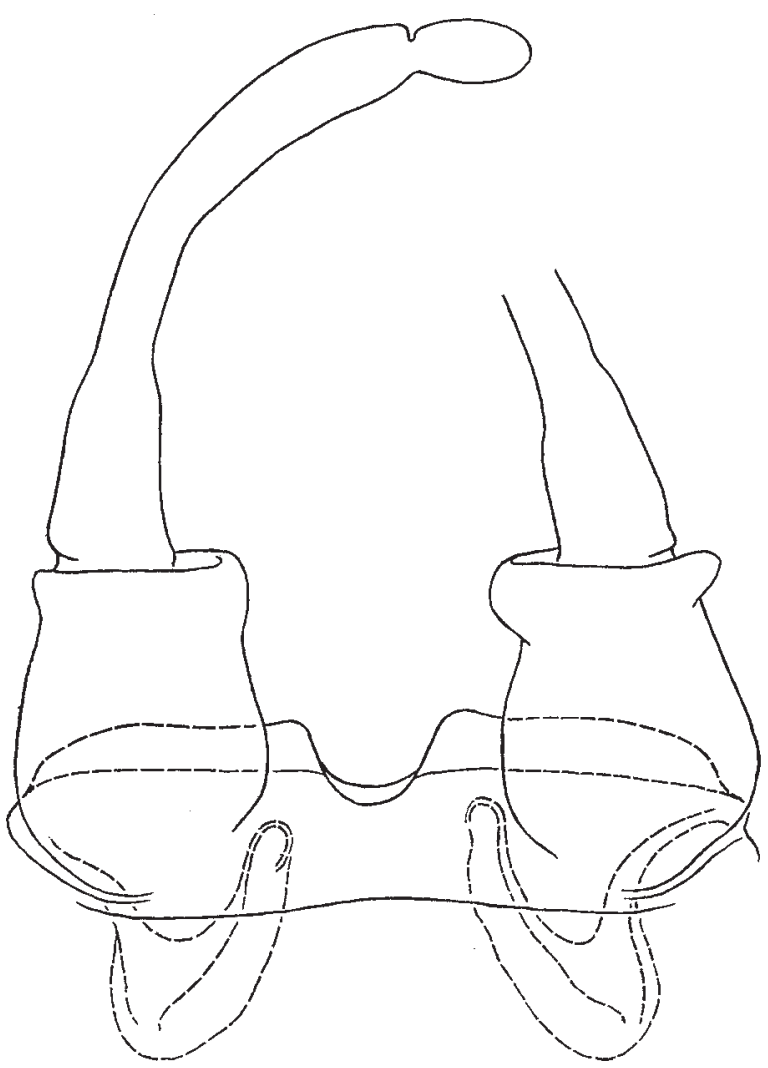

Fig. 140: Tanzaniops/g1 spinosa [Tanzaniella]. Genitals of male imago, ventral view (muscles not shown) (paratypus).

Рис. 140: Tanzaniops/g1 spinosa [Tanzaniella]. Гениталии самца имаго, вентрально (мышцы не показаны) (паратип).

Possible ranking names in non-phylogenetic classifications:

— genus Jubabaetis;

- subgenus Jubabaetis in genus Acentrella;

- subgenus Jubabaetis in genus Baetis.

This holophyletic taxon is circumscribed here for the first time. It consists of species formerly placed to the Oriental genera Liebebiella, Jubabaetis and Platybaetis.

Autapomorphy.

(1) Larval tarsus of each leg bears a long ventral subapical seta, which is much longer than all other setae on the tarsus. This seta is nearly always single; only for Jubabaetis/ g3 pescadori Müller-Liebenau, 1980 [Jubabaetis] two setae are described; another, undescribed species of Jubabaetis/g3 from East Malaysia, has a single seta on each leg.

Plesiomorphy. Unlike Tanzaniops, mentum has paraglossal muscle oblique and overlapping glossal muscle ventrally.

Distribution. Oriental Region.

DISCUSSION. Besides Jubabaetis/g2, the same subapical seta is known only for Papuanatula Lugo-Ortiz \& McCafferty, 1999. Systematic position of Papuanatula is unknown. Like Jubabaetis/g2 and all other Acentrella/fg1, Papuanatula has a regular row of setae on tibiae. Unlike Jubabaetis/g2 and other Baetofemorata, Papuanatula has no femoral patch. Mola of left mandible in Papuanatula has no features peculiar for Jubabaetis/g1 (see above). Genital structure of Papuanatula is unknown. I was able to examine a single female larva of undescribed species of Papuanatula from Sulawesi.
COMPOSITION. Jubabaetis/g2 is divided into plesiomorphon Liebebiella and holophyletic taxa Platybaetis and Jubabaetis/g3.

\section{C.1.2.2.1. Plesiomorphon Liebebiella/g(1), or Liebebiella}

(Figs 141-169, 171-175)

Systematic position: Acentrella/fg1-Jubabaetis/g1-g2pm.Liebebiella

Hierarchical typified name: Liebebiella/g(1) [g: Liebebiella Waltz \& McCafferty, 1987b, typus Pseudocloeon orientale MüllerLiebenau, 1982 (design. orig.)]

Possible ranking names in non-phylogenetic classifications:

— genus Liebebiella;

- subgenus Liebebiella in genus Jubabaetis;

- subgenus Liebebiella in genus Acentrella;

- subgenus Liebebiella in genus Baetis.

REFERENCE: Waltz \& McCafferty, $1987 \mathrm{~b}$ (larva)

Being characterized by plesiomorphies only, this taxon can be paraphyletic, i.e. ancestral to Jubabaetis/g3 and Platybaetis.

Plesiomorphies.

(1) Unlike Jubabaetis/g3, larval terga lack median hooks; they can be either smooth, or with small tubercles (Fig. 150).

(2) Unlike Platybaetis, larva has the same shape as in other Acentrella/fg1 (as in Fig. 18).

DISTRIBUTION. Oriental Region.

SPECIES COMPOSITION. The following species are described as larvae only: ambiguum Müller-Liebenau, 1982 [Pseudocloeon], atoki Müller-Liebenau, 1982 [Pseudocloeon], difficilum Müller-Liebenau, 1982 [Pseudocloeon], klapaleki Müller-Liebenau, 1982 [Pseudocloeon], orientale Müller-Liebenau, 1982 [Pseudocloeon], proximum MüllerLiebenau, 1984 [Pseudocloeon], siveci Braasch, 1983 [Pseudocloeon]. Here we describe larvae and adults of verum Müller-Liebenau, 1982 [Pseudocloeon] (= deigma Waltz \& McCafferty, 1987b [Liebebiella] syn.n.), bispinosa sp.n. [Acentrella (Liebebiella)] and cylindroculata sp.n. [Acentrella (Liebebiella)]. Species examined are reviewed below.

\section{C.1.2.2.1-1. Liebebiella/g(1) verum [Pseudocloeon]} (Figs 141-149, 171)

Systematic position: Acentrella/fg1-Jubabaetis/g1-g2Liebebiella.

Original binomen: Pseudocloeon verum Müller-Liebenau, 1982. Subjective synonym: Liebebiella deigma Waltz \& McCafferty, 1987b syn.n.

Possible binomina:

- Liebebiella vera;

- Jubabaetis (Liebebiella) verus;

- Acentrella (Liebebiella) vera

- Baetis (Liebebiella) verus;

- Baetis (Jubabaetis) verus;

- Baetis (Acentrella) verus.

REFERENCES: Pseudocloeon sp.1: Ulmer, 1939; Müller-Liebenau, 1981 (larva); 1982; Pseudocloeon kraepelini: Müller-Liebenau, 1981 (non Klapalek, 1904); group verum: Müller-Liebenau, 1982 (larva); Pseudocloeon verum Müller-Liebenau, 1982 (larva); Liebebiella vera and Liebebiella deigma: Waltz \& McCafferty, 1987b.

MATERIAL. INDONESIA: Java: Cipanas (30 km SE Bogor), 6-11.VIII.2009, coll. N. Kluge \& L. Sheyko: 4 L-S-IO', 4 L-S-I + , 26 L-S $\sigma^{7}, 8 \mathrm{~L}-\mathrm{S}+, 110$ larvae; the same place, 26.II.2006, coll. S. Melnitsky: $2 \mathrm{~S}^{7}, 1 \mathrm{~S}$. Bogor, botanic garden, 24.II.2008, coll. V. Ivanov: $3 \mathrm{I}^{7}, 67 \mathrm{I}+3 \mathrm{~S} \sigma^{\top}$. Mt. Sulak, Ciapus (near Bogor), 24.II.2008, coll. V. Ivanov: 6 larvae. Lombok: Senaru, Sindanggala waterfalls, 19-26.IX.2009, coll. N. Kluge \& L. Sheyko: 4 L-S-IO', 5 L-S-I $\bigcirc, 2$ L-S ${ }^{7}, 1$ L-S 9 , 14 larvae; the same place, 2.III.2008, coll. V. Ivanov: 17 I오. Sembulan, Lawang, 5.III.2008, coll. V. Ivanov: 13 I +. Manis waterfall, 7.III.2008, coll. S. Melnitsky: 1 I $9,1 \mathrm{~S}^{\top}$, 1S ${ }^{\circ}$. MALAYSIA, negeri Pahang, Cameron highlands, 1.IX.1994, coll. S.C. Kang: 7 larvae. 
MATERIAL PRESUMABLY ATTRIBUTED TO THIS SPECIES: THAILAND, Chiang Mai, mount Doi Suthen, 4-5.01.1998, coll. V. Ivanov: 2 larvae, 6 I,$+ 2 \mathrm{~S}+; 20 \mathrm{~km} \mathrm{~N}$ Chiang Mai, Queen Sirikit botanical garden, 7.I.1998, coll. V. Ivanov: $1 \mathrm{SO}^{7}$.

Larva. Described by Müller-Liebenau [1981, 1982] as Pseudocloeon sp.1, Pseudocloeon verum and 'group verum'.

Cuticular COlORATION: Head and thorax have cuticle brown with lighter and darker areas; pronotum has dark sigilla (as in Fig. 133). Thoracic pleura dark, sterna colorless. Abdominal terga brown with light blanks; medioposterior sigilla roundish, expressed on some segments as dark spots on blanks (as in Fig. 110); sterna at most part light. Each femur light in proximal and distal parts, with extreme base and apex dark, and with a large diffusive irregular dark macula in middle part. Cuticle of cerci uniformly brown.

Hypodermal coloration: Abdomen of mature larva can have characteristic contrasting reddish median marks on terga III and VI, as in imago (Figs 143, 171); these hypodermal marks can be better or worthier visible through cuticular coloration; in some specimens these marks absent.

SHAPE AND SETATION: Frons somewhat projected above clypeus, with very fine, short, colorless, dens setae directed dorsally and posteriorly (as in Fig. 124) (being very small and light, these setae poorly visible). Scapus of antenna slightly asymmetric, with median side longer than lateral side (as in

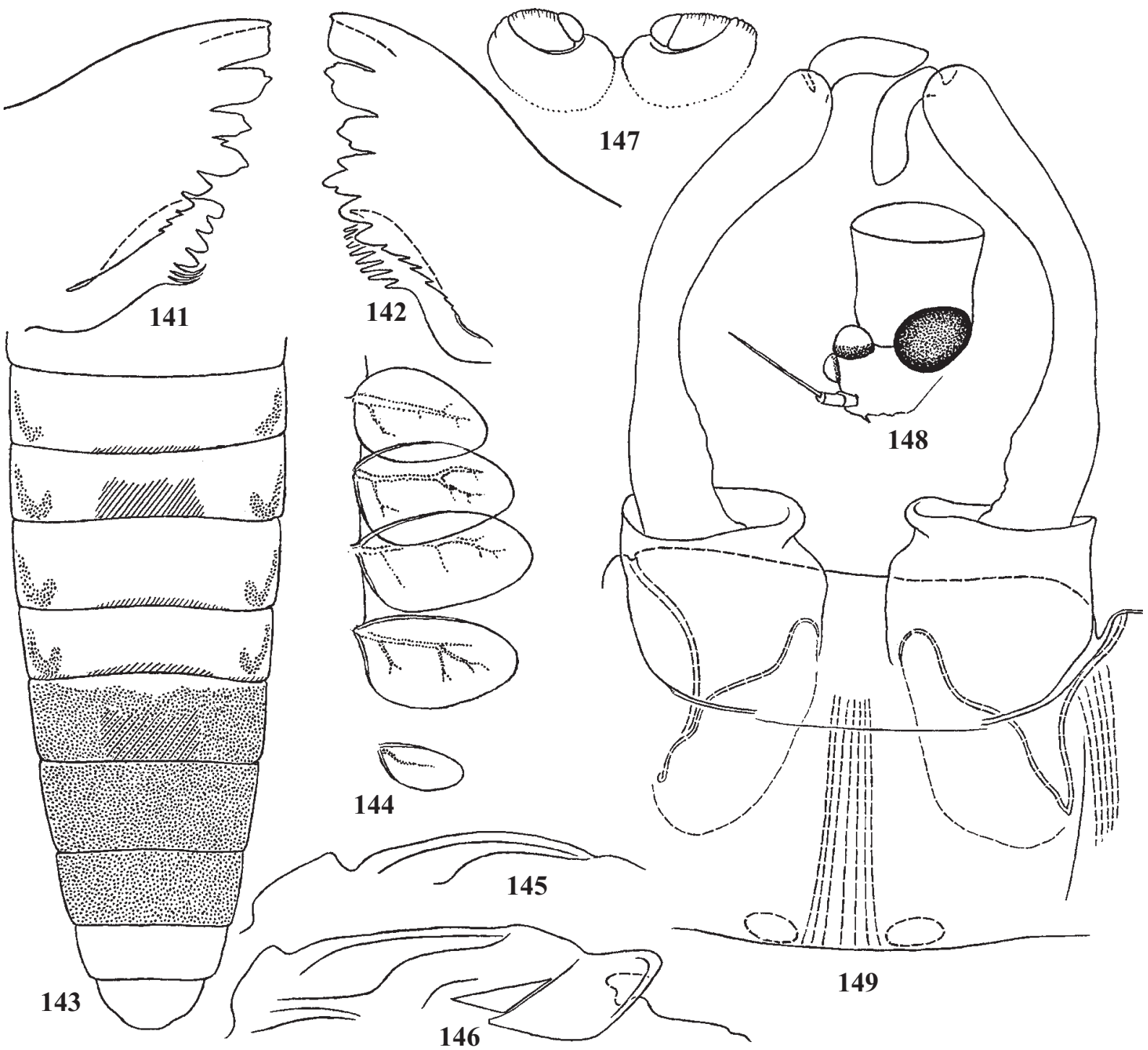

Figs 141-149. Liebebiella/g1 verum [Pseudocloeon]: 141-142 — apices of left and right mandibles (new cuticle before molt);143 abdominal terga of male imago, spread on slide (brown pigmentation shown by dots, red pigmentation shown by oblique lines); 144 - tergalii I-III and VII; 145-146 — imaginal mesonotum, lateral view; 147 — buds of subimaginal gonostyli folded under larval cuticle; 148 — head of male imago, lateral view; 149 - genitals of male imago, ventral view (gonostylar muscles and left gonovectal muscle not shown; for explanation see Fig. 3).

Рис. 141-149. Liebebiella/g1 verum [Pseudocloeon]: 141-142 - вершины левой и правой мандибул (новая кутикула перед линькой); 143 - тергиты брюшка самца имаго, расправленные на препарате (бурая пигментация показана пунктировкой, красная пигментация показана косыми линиями); 144 - тергалии I-III и VII; 145-146 — имагинальный мезонотум, латерально; 147 зачатки субимагинальных гоностилей, сложенные под личиночной кутикулой; 148 - голова самца имаго, латерально; 149 гениталии самца имаго, вентрально (гоностилярные мышцы и мышца левого гоновектиса не показаны; объяснение на рис. 3). 
Fig. 153). Labrum short and wide, narrowing toward apex [Müller-Liebenau, 1981: Fig.4a; 1982: Fig. 1a]. Mandibles not blade-like (Figs 141, 142) [Müller-Liebenau, 1981: Fig.4e; 1982: Fig. 1f]. Labium has paraglossal muscle oblique and fan-like; $2^{\text {nd }}$ palpomere has muscle (as in Fig. 152), $2^{\text {nd }}$ palpomere has length subequal to width, $3^{\text {rd }}$ palpomere has length less than width [Müller-Liebenau, 1981: Fig.4b; 1982: Fig. 1b]. Thoracic sterna have no prominent subfurcal protuberances. Hind protoptera have form of small vestiges (as in Fig. 125). Legs long. Femora of all legs have subequal length. On hind leg length of tibia subequal to length of femur; on middle and fore legs tibia longer, 7/6 of femur length. Tarsus of hind leg about 3 times shorter than tibia; tarsus of middle leg longer and tarsus of fore leg the longest, about 2.5 times shorter than tibia. On fore leg femur widest in proximal part, its width 0.3 of length; on middle and hind legs femur slightly thinner, equally wide at most its length. Tibiae thin, patella occupies less than $1 / 2$ of inner tibial margin. Setae forming the regular row on external margin of femur, have length more than $1 / 2$ of femur width. Setae forming the regular row on dorsal margin of tibia [see Acentrella/fg1 (3)] long, about 1.5 times exceeding tibia width. Hind tibia has a second (external) regular row of setae, which are as long as setae of dorsal row, but thinner and lighter. Setae forming the row on dorsal margin of tarsus much smaller and sparse. Inner margin of tarsus bears 2-4 short stout setae and a long subapical seta (characteristic for Jubabaetis/g2). Claw has 8-10 denticles; subapical setae vestigial. Abdominal terga widened: width of spread abdominal tergum II between tergalii bases 4-4.5 times exceeds its length. Abdominal terga with numerous long translucent scales. Denticles on posterior margins of terga vary individually from short and blunt to long and pointed. On abdominal sterna II-IX paired fields of dentate protuberances transverse, narrow, locate only laterad of medioposterior sigilla (as in Fig. 99). Tergalii elongate and asymmetric, sharply widened basally-posteriorly [MüllerLiebenau, 1982: Fig. 1]. In specimens from Lombok tracheae of tergalii very contrasting, dark brown; in specimens from Cipans tracheae lighter. Vestige of paracercus short, but multisegmented (consists of 10-15 segments); subimaginal vestige of paracercus develops in it with wastes. Cerci subequal to body length. Primary swimming setae developed: absent on several proximal segments; one or a few on each next segment; about 10 setae with strongly pressed transverse bases on each middle segment; absent on several last segments.

Subimago. Cuticular coloration. Thoracic sclerites brown; mesonotum brown with contrasting colorless medioparapsidal sutures. Cuticle of legs and abdomen light. Wings light.

Hypodermal coloration. As in imago.

Imago, male. Head yellowish with brownish. Turban eyes nearly cylindrical, very slightly widened apically (Fig. 148), uniformly red. Prothorax has notum brown; pleura, sterna and coxae whitish. Pterothorax has light brown and ocher maculae. Mesonotum ocher, lateral parts light brown; posterior margin of anteronotal protuberance, median suture and medioparapsidal sutures bordered by brown. Anteronotal protuberance has shape usual for Acentrella/fg1 (Figs 145, 146). Pleurites of meso- and metathorax have membranes ocher, sclerites brown. Coxae of middle and hind legs brown. Mesosternum at most brown, metasternum pale brownish. On fore leg femur has proximal half colorless, distal half brown or reddish, apex ocher; tibia colorless, with inner margin darkened; tarsus pale brownish. Middle and hind legs at most colorless, femur with more or less expressed light reddish band near apex. On fore leg legs femur slightly longer than in larva and subimago; tibia 1.7 of femur length; tarsus shorter than tibia, 1.4 of femur length. On middle and hind legs femur has the same length as in larva and subimago; tibia longer than in larva (the same in subimago); both on middle and hind legs tibia longer than femur; tarsus has the same length as in larva. On middle and hind legs tarsus has 3 apical spines: $1^{\text {st }}+2^{\text {nd }}, 3^{\text {rd }}$ and $4^{\text {th }}$ tarsomeres are spine-bearing (as in Fig. 5) [see Jubabaetis/g1 (2)]. Fore wing has basal sclerite light brown; veins light; pterostigma whitish, with 2-3 incomplete crossveins. Abdominal segments II-V translucent, at most colorless; each tergum II-V has a pair of lateral hook-like grayish-brown stripes; terga II-IX or a part of them with a narrow reddish or brown line on posterior margin; terga III and VI usually with a large median contrasting reddish macula; terga VI-VIII light brown; tergum IX whitish (Figs 143, 171). Sterna II-V colorless, sterna VI-IX brownish. Distal part of sternum IX and genitals colorless. Each unistyliger has median side convex, inner-distal margin projected; $2^{\text {nd }}$ segment of gonostylus widened apically, $3^{\text {rd }}$ segment elongate; penial bridge membranous; gonovectes colorless, very thin, long, sharply angulate, with characteristic undulation; styligeral muscle narrow (Fig. 149). Cerci uniformly light.

Imago, female. Head and thorax ocher-and-brown, as in male. Color of legs as in male. On fore leg tarsus has 2 apical spines: $2^{\text {nd }}$ and $3^{\text {rd }}$ tarsomeres are spine-bearing, while $4^{\text {th }}$ tarsomere (penultimate, with stretched apical-ventral angle) lacks apical-ventral spine; on middle and hind legs tarsus has 3 apical spines: $1^{\text {st }}+2^{\text {nd }}, 3^{\text {rd }}$ and $4^{\text {th }}$ tarsomeres are spinebearing (as in male) (as in Fig. 5) [see Jubabaetis/g1 (2)]. Abdomen ocher, terga VI-VIII darker, tergum IX lighter; some specimens have contrasting red maculae on terga III and VI; some specimens have reddish-brown lines on posterior margins of terga (similar to that of male).

Egg. Length about $0.10-0.11 \mathrm{~mm}$.

Dimension. Fore wing length $4 \mathrm{~mm}$; a few females are larger, with fore wing length up to $5 \mathrm{~mm}$.

DISTRIBUTION. Malacca Peninsula and island Sumatra, Java, Bali, Lombok.

COMMENT. Müller-Liebenau [1982] described the new species Pseudocloeon verum from Malaysia and redescribed the Ulmer's [1939] Pseudocloeon sp. 1 from Sumatra; the both species were known as larvae only and were distinguished one from another only by shape and size of the submarginal bristles near outer margin of femur. Actually, these bristles are nearly the same even on figures in her paper; individual variability of these bristles does not allow to find the difference. Waltz \& McCafferty [1987b] gave a new species name Liebebiella deigma for the Ulmer's [1939] Pseudocloeon sp. 1; they referred only to the descriptions made by Ulmer [1939] and Müller-Liebenau [1981, 1982], but did not give any new diagnosis. Thus, Liebebiella deigma Waltz \& McCafferty, 1987 is the junior synonym of Pseudocloeon verum Müller-Liebenau, 1982.

Müller-Liebenau [1982] united Pseudocloeon verum and Pseudocloeon sp. 1 to a group verum; among other characters of this group, she noted "serrated antennal segments". This serration represents very short dark setae, irregularly situated on one side of several proximal segments of flagellum; density of these setae varies individually. In other species flagellum also has small setae of this or that shape and density, so this character if difficult for use.

Male imagoes and subimagoes of verum [Pseudocloeon] can be determined by very slender and characteristically undulating gonovectes. Larvae can be determined by combination of characters (see Table 2). 


\section{C.1.2.2.1-2. Liebebiella/g(1) bispinosa sp.n. [Acentrella (Liebebiella)] \\ (Figs 150-161, 172)}

Systematic position: Acentrella/fg1-Jubabaetis/g1-g2-Liebebiella.

Original binomen: Acentrella (Liebebiella) bispinosa Kluge \& Novikova, sp.n.

Possible binomina:

- Liebebiella bispinosa;

- Jubabaetis (Liebebiella) bispinosus;

- Acentrella (Liebebiella) bispinosa;

- Baetis (Liebebiella) bispinosus;

- Baetis (Jubabaetis) bispinosus;

- Baetis (Acentrella) bispinosus.

MATERIAL. Holotype: L-S-IO', INDONESIA, Sulawesi, tributary of river Mamasa $5 \mathrm{~km}$ W Mamasa, 19.VIII.2009, coll. N. Kluge \& L. Sheyko, specimen [VIII](14)AA. Paratypes: the same locality, 15-27.VIII.2009: 5 L-S-I $\sigma^{7}, 2$ L-S-I,+ 4 L-S $\sigma^{7}, 9$ L-S +110 larvae.

Larva. Cuticular coloration: Head and thorax have cuticle brown with diffusive lighter and darker areas; pronotum dark, nearly unicolor, or with poorly expressed light sigilla. Cuticle of abdominal terga either nearly unicolor brown, or with diffusive blanks and dark roundish medioposterior sigilla; sometimes cuticle repeats hypodermal coloration (see below): terga IV-V and IX-X lighter and terga VIVIII darker. Abdominal sterna have cuticle light, darkened laterally. Each femur light in proximal and distal parts, with extreme base and apex dark, and with a large diffusive irregular dark macula in middle part. Cuticle of cerci uniformly brown.

HyPODERMAL COLORATION: Abdomen of mature larva has characteristic hypodermal color as in imago (see below).

SHAPE AND SETATION: Frons somewhat projected above clypeus, with very fine, short, colorless, dens setae directed dorsally and posteriorly (being very small and light, these setae poorly visible). Scapus of antenna slightly asymmetric, with median side longer than lateral side (Fig. 153). Labrum has medium proportions, its length somewhat exceeds $1 / 2$ of width. Mandibles blade-like: incisor very long and pointed; kinetodontium reduced to a few denticles, which lie on the same line with median margin of incisor (Fig. 154-155) (in most specimens incisor is wore out). Left prostheca more slender than in cylindtroculata $[A$.], denticles occupy less than $1 / 2$ of its length (Fig. 154). Labium has paraglossal muscle oblique and fanlike; $2^{\text {nd }}$ palpomere has length exceeding width, with muscle; $3^{\text {rd }}$ palpomere has length equal to width (Fig. 152). Thoracic sterna have no prominent subfurcal protuberances. Hind protoptera have form of small vestiges (as in Fig. 125). Legs long and thin. Femora of all legs have subequal length or hind femur slightly longer than fore femur. On hind leg length of tibia subequal to length of femur; on middle leg tibia longer and on fore leg tibia longest, 5/4 of femur length. Tarsus of hind leg about 2.5 times shorter than tibia; tarsus of middle leg has the same length, about 3 shorter than tibia; tarsus of fore legs slightly longer. On fore leg femur widest in proximal part, its width 0.34 of length; on middle and hind legs femur equally wide at most its length, its width 0.27 of length. Tibiae thin, with patella-tibial suture deep and wide; patella occupies more than $1 / 2$ of inner tibial margin. Setae forming the regular row on external margin of femur, have length more than 1/2 of femur width. Setae forming the regular row on dorsal margin of tibia [see Acentrella/fg1 (3)] long, their length 2 times exceeds tibia width; second (external) row of long setae absent. Setae forming the row on dorsal margin of tarsus much smaller and sparse. Inner margin of tarsus bears 2-4 short stout setae and a long subapical seta (characteristic for Jubabaetis/g2). Claw has 8-10 denticles; subapical setae vestigial. Abdominal terga widened: width of spread abdominal tergum II between tergalii bases 4.5 times exceeds its length. Abdominal terga bear submedian paired spines or protuberances, which are most high and prominent on anteriormost segments and disappear toward the last segments (Fig. 150). Abdominal terga have no scales; denticles on posterior margins of terga conic, developed on posterior segments, absent or irregular on anterior segments (Fig 150). On abdominal sterna II-IX paired fields of dentate protuberances transverse, narrow, locate only laterad of medioposterior sigilla (as in Fig. 99). Tergalii roundish; costal and anal ribs small; tergalius VII much smaller than others (Fig. 150). Vestige of paracercus short and one-segmented, subimaginal vestige of paracercus develops in it without wastes. Cerci subequal to body length. Segments of cerci lack marginal denticles. Primary swimming setae lost; their vestiges retained on middle segments as light spots (remnants of setae bases): each two segments have only one spot, so that segments with and without a spot alternate (Fig. 156); segments of proximal and distal part of cerci have no such spots.

Subimago. Cuticular COlORATION. Most part of cuticle light brownish. Prealar bridge, narrow sclerotization of epimeron, lateropostnotal crest, longitudinal stripe on junction of metanotum with metapleura and some other sclerites dark brown. Wings light.

Hypodermal coloration. As in imago.

Imago, male. Head and thorax brown. Turban eyes cylindrical (Fig. 160), uniformly red. Anteronotal protuberance low and blunt (Fig. 159), unlike most other Acentrella/fg1. On fore leg femur uniformly brown, tibia and tarsus light. On middle and hind legs femur in most part colorless, extreme base and apical 1/4 brown; tibia and tarsus light. On fore leg femur has the same length as in larva; tibia 1.6 of femur length; tarsus shorter than tibia, subequal to femur length. On middle and hind leg length of femur, tibia and tarsus as in larva: their femora equal; on hind leg tibia equal to femur; on middle leg tibia longer than femur. On middle and hind legs tarsus has 3 apical spines: $1^{\text {st }}+2^{\text {nd }}, 3^{\text {rd }}$ and $4^{\text {th }}$ tarsomeres are spine-bearing (as in Fig. 5) [see Jubabaetis/g1 (2)]. Fore wing has basal sclerite light brown; veins light; pterostigma whitish, with 3-4 incomplete crossveins. Abdominal terga II-III can bear small paired protuberances, which correspond to larval spines. Abdominal segments II-VI translucent. Abdominal terga have characteristic contrasting dark brown maculae on whitish background (Figs 158, 172): tergum II has a pair of dark brown maculae; tergum III has dark brown median part; terga VI and $\mathrm{V}$ at most part light; terga VI-VIII at most part dark brown; tergum IX at most part light; lateral tracheal trunks bordered with brown. Sterna II-VI colorless; sterna VII-IX light brownish. Styliger and $1^{\text {st }}$ segments of gonostyli light brownish, $2^{\text {nd }}$ $3^{\text {rd }}$ segments of gonostyli colorless. Each unistyliger has median side convex, inner-distal margin projected; $1^{\text {st }}$ segment of gonostylus parallel-sided; $2^{\text {nd }}$ segment long and nearly parallelsided, slightly widened apically; $3^{\text {rd }}$ segment small; penial bridge light brownish, incised medially; gonovectes brown, thin and long, sharply angulate, with a small thin hook-like sclerite arising from angle; styligeral muscle narrow (Fig. 161). Cerci uniformly light.

Imago, female. Head and thorax ocher-brown, lighter than in male. Color of legs as in male. On fore leg tarsus has 2 apical spines: $2^{\text {nd }}$ and $3^{\text {rd }}$ tarsomeres are spine-bearing, while $4^{\text {th }}$ tarsomere (penultimate, with stretched apical-ventral angle) lacks apical-ventral spine; on middle and hind legs tarsus has 3 apical spines: $1^{\text {st }}+2^{\text {nd }}, 3^{\text {rd }}$ and $4^{\text {th }}$ tarsomeres are spine-bearing (as in male) (as in Fig. 5) [see Jubabaetis/g1 (2)]. Abdomen ocher, with contrasting dark brown maculae similar to that of male. 


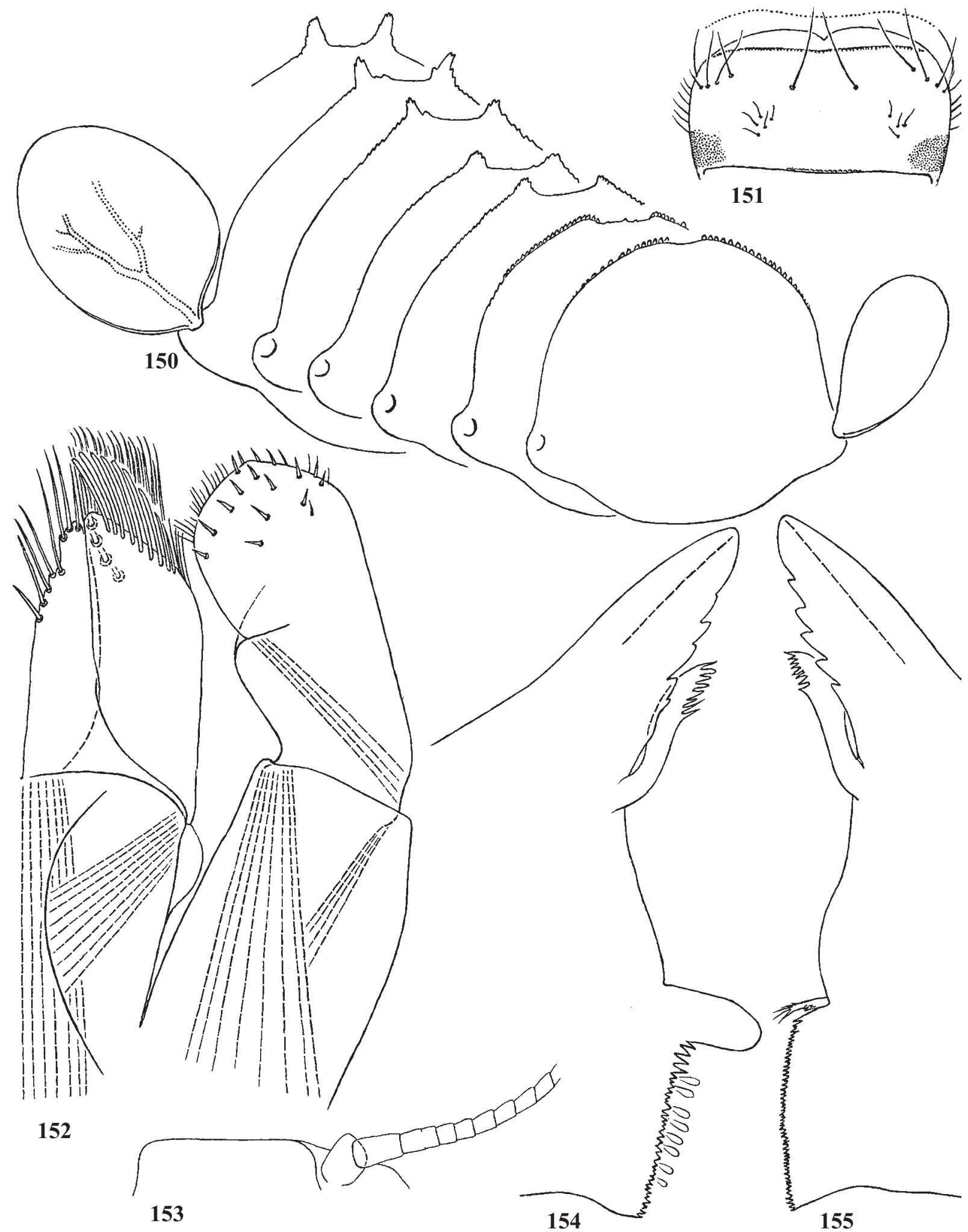

Figs 150-155. Liebebiella/g1 bispinosa sp.n. [Acentrella (Liebebiella)], larva: 150 — abdominal segments I-VII, view from behind; 151 — labrum; 152 — half of labium, ventral view (muscles shown by interrupted lines); 153 — frons and base of right antenna; 154-155 — left and right mandibles.

Рис. 150-155. Liebebiella/g1 bispinosa sp.n. [Acentrella (Liebebiella)], личинка: 150 - I-VII сегменты брюшка, вид сзади; 151 верхняя губа; 152 - половина нижней губы, вентрально (мышцы показаны прерывистыми линиями); 153 - лоб и основание правой антенны; 154-155 — левая и правая мандибулы. 
Egg. Length about $0.10-0.11 \mathrm{~mm}$.

Dimension. Fore wing length $4 \mathrm{~mm}$.

COMPARISON. Larva of the new species differs from all other known species of Acentrella/fg1 by paired spines on anterior abdominal terga; terga of other species either have no spines, or have unpaired spines. Imago of the new species can be recognized by characteristic contrasting brown maculae on abdomen.

\section{C.1.2.2.1-3. Liebebiella/g(1) cylindroculata sp.n. [Acentrella (Liebebiella)]}

(Figs 162-169, 173)

Systematic position: Acentrella/fg1-Jubabaetis/g1-g2-Liebebiella.

Original binomen: Acentrella (Liebebiella) cylindroculata Kluge \& Novikova, sp.n.

Possible binomina:

- Liebebiella cylindroculata:
- Jubabaetis (Liebebiella) cylindroculatus;

- Acentrella (Liebebiella) cylindroculata;

- Baetis (Liebebiella) cylindroculatus.

- Baetis (Jubabaetis) cylindroculatus.

- Baetis (Acentrella) cylindroculatus.

MATERIAL. Holotype: L-S-IO, INDONESIA, Sulawesi, tributary of river Mamasa $5 \mathrm{~km}$ W Mamasa, 19.VIII.2009, coll. N. Kluge \& L. Sheyko, specimen [VIII](14)AB. Paratypes: the same locality, 15-27.VIII.2009, 2 L-S ${ }^{7}, 4$ L-S,+ 58 larvae.

Larva. Cuticular coloration: Head and thorax have cuticle brown with diffusive lighter and darker areas; pronotum dark, nearly unicolor, or with poorly expressed light sigilla. Cuticle of abdominal terga nearly unicolor brown, or with diffusive blanks and dark roundish medioposterior sigilla; terga IX-X lighter than others or colorless. Abdominal sterna have cuticle light, darkened laterally. Each femur light in proximal and distal parts, with extreme base and apex dark, and with a large diffusive irregular dark macula in middle part. Cuticle of cerci uniformly brown.

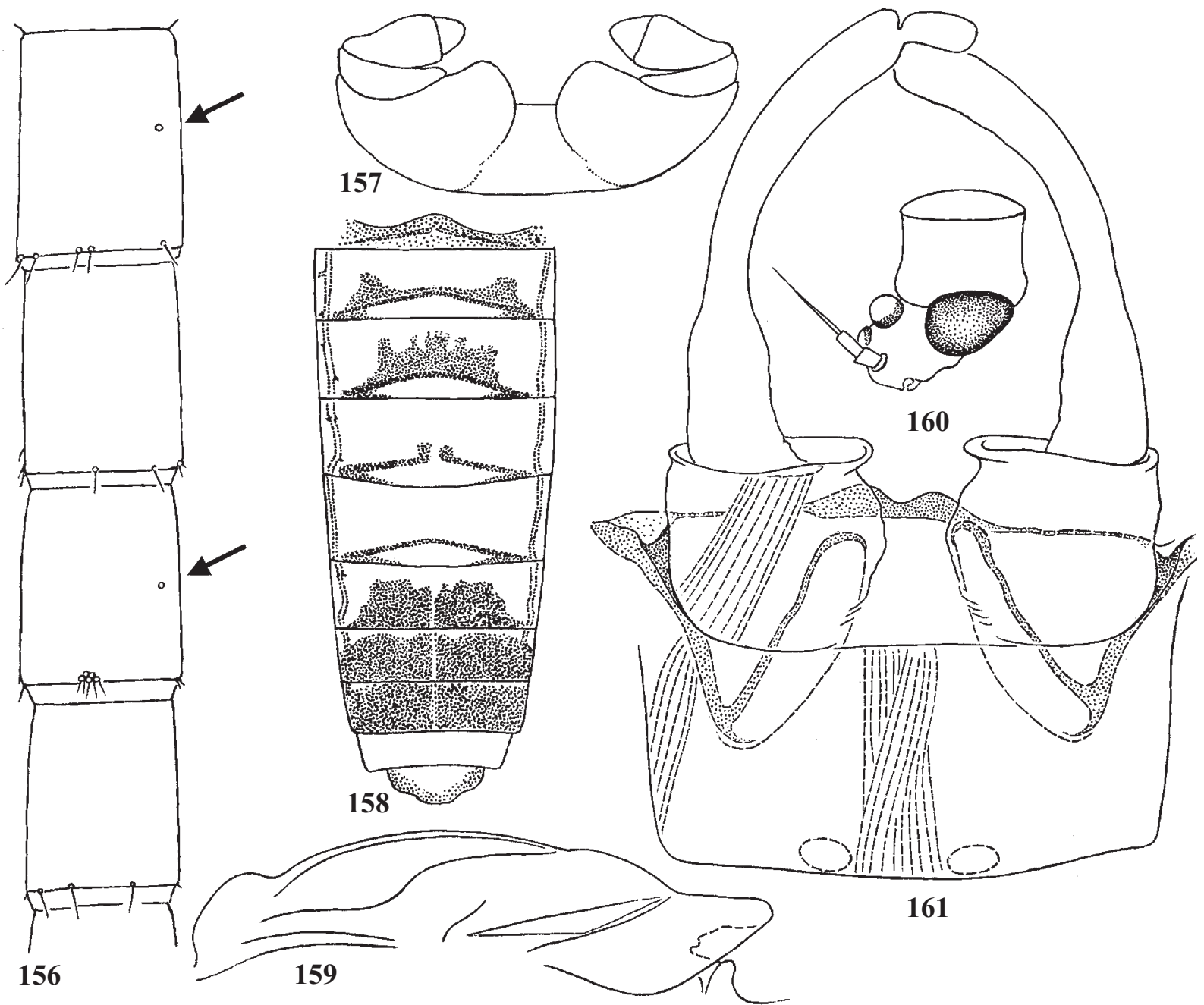

Figs 156-161. Liebebiella/g1 bispinosa sp.n. [Acentrella (Liebebiella)]: 156 - middle part of larval cercus (arrows show vestigial bases of primary swimming setae) (holotype); 157 — buds of subimaginal gonostyli folded under larval cuticle; 158 — abdominal terga of male imago, spread on slide (brown pigmentation shown by dots); 159 - imaginal mesonotum, lateral view; 160 — head of male imago, lateral view; 161 - genitals of male imago, ventral view (right gonostylar muscle and right gonovectal muscle not shown; for explanation see Fig. 3).

Рис. 156-161. Liebebiella/g1 bispinosa sp.n. [Acentrella (Liebebiella)]: 156 - средняя часть церка (стрелки показывают вестигии оснований первичных плавательных щетинок) (голотип); 157 - зачатки субимагинальных гоностилей, сложенные под личиночной кутикулой; 158 - тергиты брюшка самца имаго, расправленные на препарате (бурая пигментация показана пунктировкой); 159 имагинальный мезонотум, латерально; 160 - голова самца имаго, латерально; 161 — гениталии самца имаго, вентрально (гоностилярные мышцы и мышца правого гоновектиса не показаны; объяснение на рис. 3). 


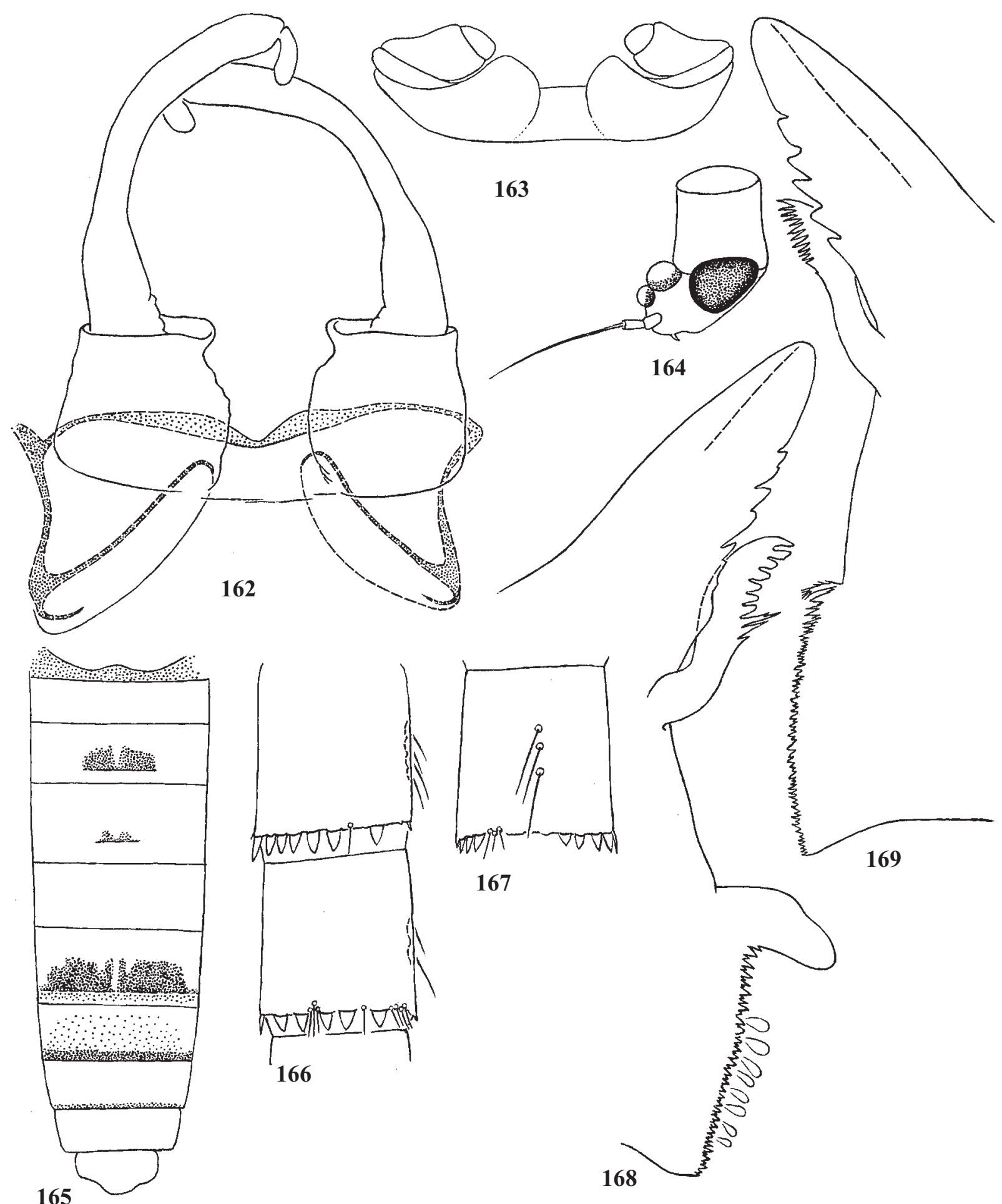

Figs 162-169. Liebebiella/g1 cylindroculata sp.n. [Acentrella (Liebebiella)]: 162 - genitals of male imago, ventral view (muscles not shown) (holotype); 163 — buds of subimaginal gonostyli folded under larval cuticle; 164 - head of male imago, lateral view; 165 abdominal terga of male imago, spread on slide (brown pigmentation shown by dots); 166 — middle part of larval cercus, dorsal view (holotype); 167 - segment from middle part of larval cercus, median view; 168-169 - left and right mandibles.

Рис. 162-169. Liebebiella/g1 cylindroculata sp.n. [Acentrella (Liebebiella)]: 162 - гениталии самца имаго, вентрально (мышцы не показаны) (голотип); 163 - зачатки субимагинальных гоностилей, сложенные под личиночной кутикулой; 164 - голова самца имаго, латерально; 165 - тергиты брюшка самца имаго, расправленные на препарате (бурая пигментация показана пунктировкой); 166 - средняя часть церка личинки, дорсально (голотип); 167 - членик из средней части церка личинки, вид с медиальной стороны; $168-169$ - левая и правая мандибулы. 
Hypodermal COLORATION: Abdomen of mature larva has characteristic hypodermal color as in imago (see below).

Shape and SETATION: Frons somewhat projected above clypeus, with very fine, short, colorless, dens setae directed dorsally and posteriorly (as in Fig. 124) (being very small and light, these setae poorly visible). Scapus of antenna slightly asymmetric, with median side longer than lateral side (as in Fig. 153). Labrum has medium proportions, its length somewhat exceeds $1 / 2$ of width. Mandibles blade-like: incisor very long and pointed; kinetodontium reduced to a few denticles, which lie on the same line with median margin of incisor (Fig. 168-169) (in most specimens incisor is wore out). Left prostheca more robust than in bispinosa [A.], denticles occupy not less than $1 / 2$ of its length (Fig. 168). Labium has paraglossal muscle oblique and fan-like; $2^{\text {nd }}$ palpomere has length exceeding width, with muscle; $3^{\text {rd }}$ palpomere has length equal to width (as in Fig. 152). Thoracic sterna have no prominent subfurcal protuberances. Hind protoptera have form of small vestiges (as in Fig. 125). Legs long and thin. Femora of all legs have subequal length or hind femur slightly longer than fore femur; on hind leg length of tibia subequal to length of femur; on middle and fore leg tibia longer, 5/4 of femur length; tarsus of hind leg about 2.5 times shorter than tibia; tarsus of middle leg has the same length, about 3 shorter than tibia; tarsus of fore legs slightly longer. On fore leg femur widest in proximal part, its width 0.3 of length; on middle and hind legs femur equally wide at most its length, its width 0.26 of length. Tibiae thin, with patellatibial suture deep and wide; patella occupies more than $1 / 2$ of inner tibial margin. Setae forming the regular row on external margin of femur, have length more than $1 / 2$ of femur width. Setae forming the regular row on dorsal margin of tibia [see Acentrella/fg1 (3)] long, their length 2 times exceeds tibia width; second (external) row of long setae absent. Setae forming the row on dorsal margin of tarsus much smaller and sparse. Inner margin of tarsus bears 2-5 short stout setae and a long subapical seta (characteristic for Jubabaetis/g2). Claw has 7-9 denticles; subapical setae vestigial. Abdominal terga widened: width of spread abdominal tergum II between tergalii bases 5 times exceeds its length. Unlike bispinosa [A.], abdominal terga have no spines or protuberances. Abdominal terga have no scales; denticles on posterior margins of terga conic. On abdominal sterna II-IX paired fields of dentate protuberances transverse, narrow, locate only laterad of medioposterior sigilla (as in Fig. 99). Tergalii roundish; costal and anal ribs small; tergalius VII much smaller than others (as in Fig. 150). Vestige of paracercus short and one-segmented, subimaginal vestige of paracercus develops in it without wastes. Cerci subequal to body length. Primary swimming setae lost; their vestiges retained on middle segments as rows of 1-6 light concave spots (remnants of setae bases) on each segment; some of these spots bear vestigial seta (Figs 166167); segments of proximal and distal part of cerci lack any remnants of swimming setae.

Subimago. Cuticular coloration. Most part of cuticle light brownish. Prealar bridge, narrow sclerotization of epimeron, lateropostnotal crest, longitudinal stripe on junction of metanotum with metapleura and some other sclerites dark brown. Wings light.

Hypodermal colotation. As in imago.

Imago, male. Head and thorax brown. Turban eyes cylindrical and high (Fig. 164), uniformly red. Anteronotal protuberance low and blunt (as in Fig. 159), unlike most other Acentrella/fg1. On fore leg femur uniformly brown, tibia and tarsus light. On middle and hind legs femur in most part colorless, extreme base and apical $1 / 4$ brown; tibia and tarsus light. On fore leg femur has the same length as in larva; tibia 1.8 of femur length; tarsus 1.25 to femur length. On middle and hind leg length of femur, tibia and tarsus are as in larva: their femora are equal; on hind tibia equal to femur; on middle leg tibia longer than femur. On middle and hind legs tarsus has 3 apical spines: $1^{\text {st }}+2^{\text {nd }}, 3^{\text {rd }}$ and $4^{\text {th }}$ tarsomeres are spine-bearing (as in Fig. 5) [see Jubabaetis/g1 (2)]. Fore wing has basal sclerite light brown; veins light; pterostigma whitish, with 3 incomplete crossveins. II-VI abdominal segments translucent. Abdominal terga with characteristic contrasting dark brown maculae on whitish background (Fig. 165): tergum II either entirely light, or with a small median macula; tergum III with dark brown median macula; tergum V either entirely light, or with small median macula; tergum V entirely light; tergum VI at most part dark brown; terga VII-VIII either also at most part dark, or light; tergum IX entirely light.

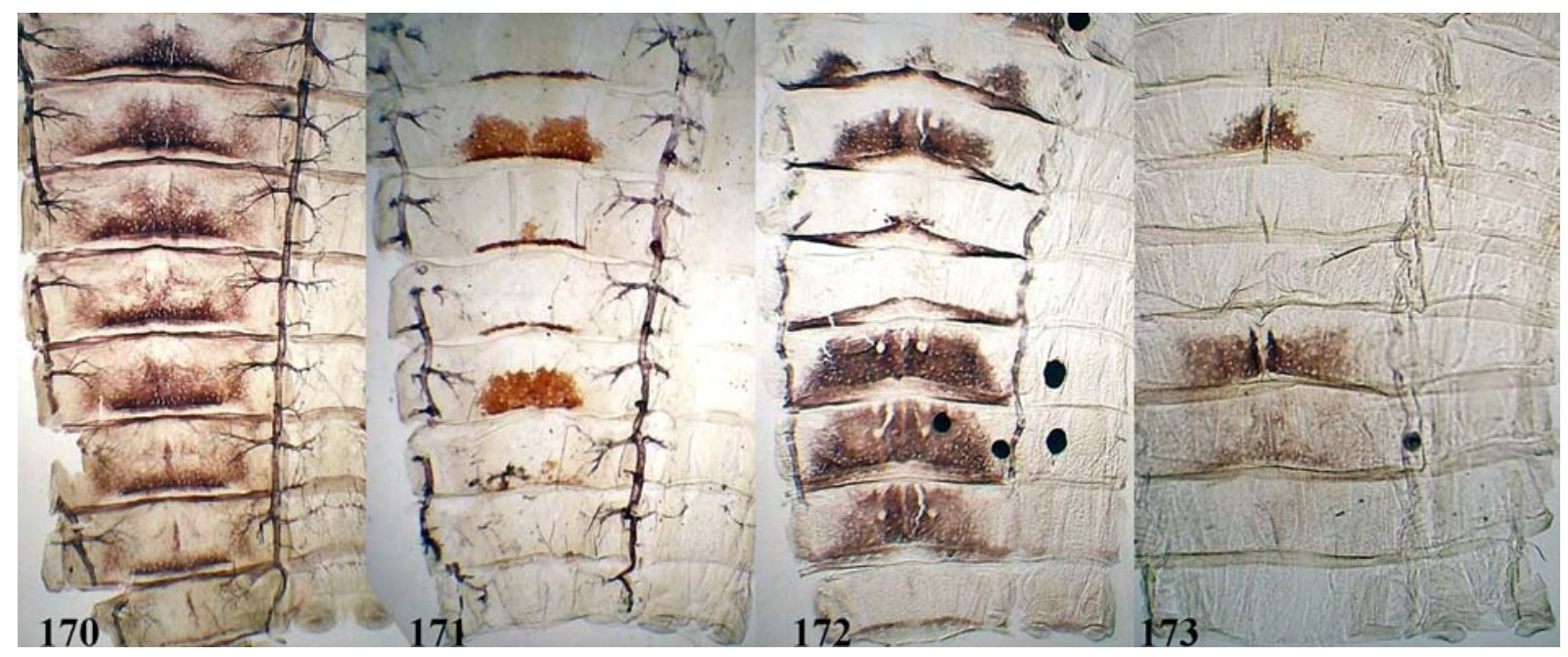

Figs 170-173. Abdomen of male subimago, spread on slide: 170 — lunamontana sp.n. [Acentrella (Tanzaniops)]; 171 — verum [Pseudocloeon]; 172 - bispinosa sp.n. [Acentrella (Liebebiella)]; 173 - cylindroculata sp.n. [Acentrella (Liebebiella)].

Рис. 170-173. Брюшко самца субимаго, расправленное на препарате: 170 — lunamontana sp.n. [Acentrella (Tanzaniops)]; 171 verum [Pseudocloeon]; 172 — bispinosa sp.n. [Acentrella (Liebebiella)]; 173 — cylindroculata sp.n. [Acentrella (Liebebiella)]. 
Sterna II-VI colorless; sterna VII-IX light brownish. Styliger and proximal parts of gonostyli light brownish, distal parts of gonostyli colorless. Each unistyliger has median side convex, inner-distal margin projected; $1^{\text {st }}$ segment of gonostylus nearly parallel-sided; $2^{\text {nd }}$ segment long and nearly parallel-sided, slightly widened apically; $3^{\text {rd }}$ segment small; penial bridge light brownish, incised medially; gonovectes brown, thin and long, sharply angulate, with a small thin hook-like sclerite arising from angle (Fig. 162). Styligeral muscle narrow (as in Fig. 161). Cerci uniformly light.

Imago, female. Unknown. Judging by subimago, similar to female of bispinosa [A.], but contrasting dark brown maculae on abdomen smaller, as in male (see above). On fore leg tarsus has 2 apical spines: $2^{\text {nd }}$ and $3^{\text {rd }}$ tarsomeres are spine-bearing, while $4^{\text {th }}$ tarsomere (penultimate, with stretched apical-ventral angle) lacks apical-ventral spine; on middle and hind legs tarsus has 3 apical spines: $1^{\text {st }}+2^{\text {nd }}, 3^{\text {rd }}$ and $4^{\text {th }}$ tarsomeres are spine-bearing (as in male) (as in Fig. 5) [see Jubabaetis/g1 (2)].

Egg. Length about $0.10-0.11 \mathrm{~mm}$.

Dimension. Fore wing length $4 \mathrm{~mm}$

COMPARISON. The new species cylindroculata $[A$.$] is$ closely related and very similar to the sympatric species bispino$s a[A$.$] ; it differs from bispinosa [A$.] by the following characters: larva has no paired spines on abdominal terga; middle segments of larval cerci have rows of vestiges of swimming setae; left prostheca is thicker, with longer row of denticles; in imago and subimago brown markings on abdominal terga are smaller; turban eyes of male imago are higher.

\section{C.1.2.2.1-4. Liebebiella/g(1) proximum [Pseudoc- loeon]}

(Fig. 174)

Systematic position: Acentrella/fg1—Jubabaetis/g1—g2—Liebebiella. 1984.

Original binomen: Pseudocloeon proximum Müller-Liebenau,

Possible binomina:

- Liebebiella proxima;

- Jubabaetis (Liebebiella) proximus;

- Acentrella (Liebebiella) proxima;

- Baetis (Liebebiella) proximus;

- Baetis (Jubabaetis) proximus;

- Baetis (Acentrella) proximus.
REFERENCES: Pseudocloeon proximum Müller-Liebenau, 1984 (larva); Liebebiella proxima: Waltz \& McCafferty, 1987 b.

MATERIAL. MALAYSIA, Sabah, Liwagu river, Kundsson, 16.VIII.1972, coll. G.F. Edmunds: 5 mature larvae.

Larva. Described by Müller-Liebenau [1984]. Some characters are shown in Table 2.

Imago and subimago. Unknown. Judging by subimaginal parts developed in mature larva, on middle and hind legs tarsus has 3 apical spines: $1^{\text {st }}+2^{\text {nd }}, 3^{\text {rd }}$ and $4^{\text {th }}$ tarsomeres are spine-bearing (as in Fig. 5); on fore leg of female tarsus has 2 apical spines: $2^{\text {nd }}$ and $3^{\text {rd }}$ tarsomeres are spine-bearing, while $4^{\text {th }}$ tarsomere (penultimate, with stretched apical-ventral angle) lacks apical-ventral spine [see Jubabaetis/g1 (2)]. Subimaginal genital buds folded under larval cuticle are shown in Fig. 174. Styligeral muscle narrow (as in Fig. 149).

\section{C.1.2.2.1-5. Liebebiella/g(1) sp. P}

(Fig. 175)

Systematic position: Acentrella/fg1—Jubabaetis/g1-g2-Liebebiella.

MATERIAL. PHILIPPINES, Luzon island, Nueva Ecija $10 \mathrm{~km}$ N Puncan, 3.V.1994, coll. S.C. Kang: 1 male larva.

Larva. By vestiges of swimming setae on cerci this species is similar to cilyndoculata [A.], but differs from cilyndoculata $[A$.] by absence of dense setae on frons (Table 2 ).

Imago, male. Unknown. Subimaginal genital buds folded under larval cuticle are shown in Fig. 175. Styligeral muscle narrow (as in Fig.149).

\section{C.1.2.2.2. Jubabaetis/g3}

(Fig. 176)

Systematic position: Acentrella/fg1-Jubabaetis/g1-g2-g3. Hierarchical typified name: Jubabaetis/g3 (sine Liebebiella, Platybaetis).

Possible ranking names in non-phylogenetic classifications:

- genus Jubabaetis;

- subgenus Jubabaetis in genus Jubabaetis;

- subgenus Jubabaetis in genus Acentrella;

- subgenus Jubabaetis in genus Baetis.

REFERENCE: genus Jubabaetis Müller-Liebenau, 1980 (larva).

Autapomorphy.

(1) Larval abdominal terga I-IX each with conspicuous, caudally directed, median hook near hind margin; long soft setae locate on median part of each tergum in front of the hook.
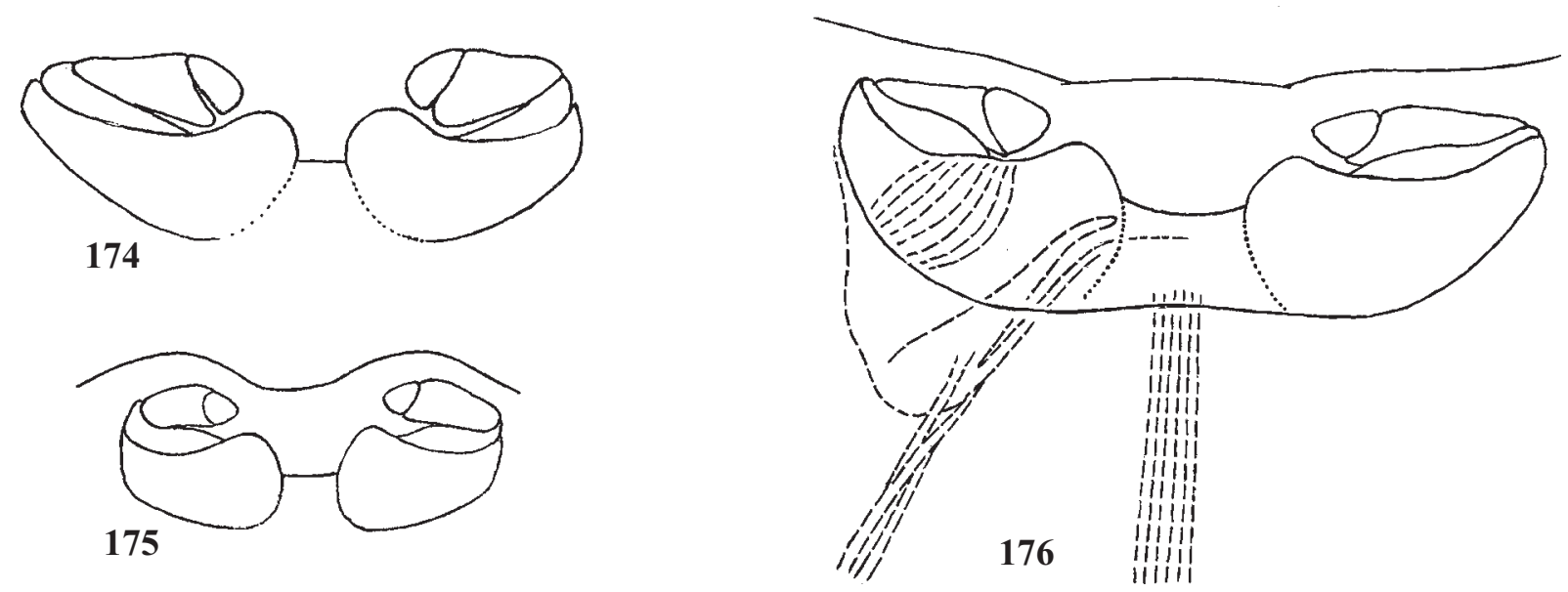

Figs 174-176. Buds of subimaginal gonostyli folded under larval cuticle: 174 — Liebebiella/g1 proximum [Pseudocloeon]; 175 — Liebebiella/g1 sp. (Philippines); 176 — Jubabaetis/g3 sp. (East Malaysia).

Рис. 174-176. Зачатки субимагинальных гоностилей, сложенные под личиночной кутикулой: 174 — Liebebiella/g1 proximum [Pseudocloeon]; 175 — Liebebiella/g1 sp. (Филиппины); 176 - Jubabaetis/g3 sp. (восточная Малайзия). 
Additional characters.

(2) In the both known species larval frons is widened, so that either touches bases of antennae (in species from Malaysia) or covers them from above (in pescadori $[\mathrm{J}$.$] ); its margin$ is covered by very dense, fine, colorless setae curved posteriorly. Nature of these setae is the same as in lunamontana $[A$. (Fig. 124), verum $[P$.], bispinosa $[A$.$] and cylindroculata [A]$. [see Jubabaetis/g1 (4)], but in Jubabaetis/g3 these setae are somewhat larger.

DISTRIBUTION. Oriental Region.

SPECIES COMPOSITION. Not less than 2 species pescadori Müller-Liebenau, 1980 [Jubabaetis] in Philippines, and an undescribed species in East Malaysia (see below).

\section{C.1.2.2.2-1. Jubabaetis/g3 sp. B1}

$$
\text { (Fig. 176) }
$$

Systematic position: Acentrella/fg1—Jubabaetis/g1—g2—g3. MATERIAL. MALAYSIA, Borneo, Sabah, Kundssang, Ranau, 4-9.IX.1999, coll. S.C. Kang: 6 larvae.

Larva. Like pescadori $[\mathrm{J}$.$] , it has long hooked pointed$ projections on abdominal terga I-IX, long soft setae anteriad of them and large tergalii.

Differs from pescadori $[\mathrm{J}$.$] by the following characters:$ Frontal shield is not so wide, does not cover antennal bases from above. Mouthpart structure is not so specialized as in pescadori $[J$.$] . Pronotum and mesonotum each bears a pair of$ long submedian projections near hind margin. Each tarsus with one long subapical seta [see Jubabaetis/g2 (1)]. Hind margin of abdominal terga with pointed denticles. Vestige of paracercus multisegmented.

Other characters as shown in Table 2. Unlike most Acentrella/fg $1,2^{\text {nd }}$ segment of labial palp lacks muscle (as in the group sibiricum).

Imago and subimago. Unknown. Judging by subimaginal parts developed in mature larva, on middle and hind legs tarsus has 3 apical spines: $1^{\text {st }}+2^{\text {nd }}, 3^{\text {rd }}$ and $4^{\text {th }}$ tarsomeres are spine-bearing (as in Fig. 5); on fore leg of female tarsus has 2 apical spines: $2^{\text {nd }}$ and $3^{\text {rd }}$ tarsomeres are spine-bearing, while $4^{\text {th }}$ tarsomere (penultimate, with stretched apical-ventral angle) lacks apical-ventral spine [see Jubabaetis/g1 (2)]. Styligeral muscle narrow (Fig.176).

\section{C.1.2.2.3. Platybaetis/g(1), or Platybaetis}

$$
\text { (Figs 177-187, 189-206) }
$$

Systematic position: Acentrella/fg1—Jubabaetis/g1-g2Platybaetis.

Hierarchical typified name: Platybaetis/g(1) [g: Platybaetis Müller-Liebenau, 1980, typus $P$. edmundsi Müller-Liebenau, 1980 (design. orig.)].

Possible ranking names in non-phylogenetic classifications:

— genus Platybaetis;

- subgenus Platybaetis in genus Jubabaetis;

— subgenus Platybaetis in genus Acentrella;

- subgenus Platybaetis in genus Baetis.

REFERENCE: genus Platybaetis Müller-Liebenau, 1980 (larva).

Holophyletic taxon, whose larvae have outstanding autapomorphic characters: they lost specialization peculiar for all other Acentrella/fg1 and got a new unusual specialization. Basing on this, Platybaetis can be opposed to all other Acentrella/fg1. For the purpose of convenience, in newly established original binomina of Platybaetis/g(1) we use the generic name Platybaetis, while in all newly established original binomina of other Acentrella/fg 1 we use the generic name Acentrella (see above).

\section{Autapomorphies.}

(1) Glossae and paraglossae, besides usual long pointed setae, have stout, blunt setae: apex of each glossa has 2 very thick, short, stout, blunt setae; apex of each paraglossa has a row of about 7 long, stout, blunt setae [Müller-Liebenau, 1980: Fig. 5e].

(2) Larva is adapted for crawling and feeding on wet rock surfaces out of the water: head is wide and flattened (see below); prothorax has unique modification (see below); abdomen is not diminished, but, vice verse, elongate, resembling the primitive siphlonuroid type [see (3)]; tergalii are very wide and spread laterally (Fig. 177). So general shape of larva strongly differs from that of other Acentrella/fg1 (compare with Fig. 18).

Prothorax (Figs 186-187) has sternal area expanded laterally, so that most part of its pleura are visible from above by sides of pronotum. Coxa of fore legs are very widely separated. Trochantins (which in mayflies are present on prothorax only) are V-shape, so that each trochantin consists of two thin stripe-like sclerites (Fig. 187: tr.a and tr.p) connected under acute angle; this angle is inserted into concavity under a peculiar paired sternal flap (Fig. 187: s.f), which projects from sternum anteriorly. Membranous area, which is bordered by coxa, episternum and trochantin, is unusually enlarged and projected anteriorly, forming a peculiar paired anterior prothoracic projection (Figs 186, 187: app). Among two stripe-like sclerites, into which trochantin is divided, the anterior one (Fig. 187: tr.a) borders the medio-anterior margin of the anterior prothoracic projection, while the posterior one (Fig. 187: tr.p) forms a lever which runs in transverse direction and connects the sternal flap with coxa. Both stripelike sclerites, which constitute trochantin, are weakly sclerotized and pale brownish. The rest sternal area, including the anterior prothoracic projections and the anterior sternal flaps, is membranous, soft and colorless. Each anterior sternal projection is thick, soft and has roundish-cone shape; most part of its surface is membranous and colorless.

Head capsule is widened and flattened, so that its hind part lies on pronotum, while its lateral parts lie on the anterior sternal projections (Fig. 177). Mouth parts, being directed ventrally, locate between the anterior sternal projections. Probably, this construction allows larva to use its mouthparts for feeding when larva lies on wet stone out of the water, being covered by a film of water, which presses its body and head to the stone. At least in the species examined, frons is not projected above clypeus (unlike all other Acentrella/fg1) and has no dense setation (unlike most other Jubabaetis/g1).

In most cases larvae of mamasae $[P$.$] and wallacei [P$.], observed in nature, were found on stones projected from the water, either just at boundary of water and air (Fig. 199), or above the water level. In the last case, larva crawls by wet stone surface, being covered by a film of water. They prefer permanently wet substrates, which are found mainly on shad sides of large stones near small waterfalls. Larva, which locates far from the water, being frightened, does not jump (unlike Mayobaetis), but runs quickly toward the water. Such running is impossible for most other mayfly larvae (including Mayobaetis) and, probably, is served by peculiar structure of prothorax and strong legs.

Besides Platybaetis, there are some other mayflies whose larvae crawl out of the water. Larvae of Neotropical Mayobaetis have usual Baetis-like appearance, but with more robust legs; they crawl by wet stones like Platybaetis; unlike Platybaetis, larvae of Mayobaetis, being frightened, do not run toward the water, but jump very far, using unusually strong abdomen. Structure of prothorax of Platybaetis is not repeated in other mayfly larvae which crawl out of the water; it is unique among mayflies and insects in general.

(3) Abdomen [initially shortened - see Acentrella/fg1 (2)] is secondarily elongate. Abdominal terga II-IX have 
medioanterior sigilla separated from anterior margin and forming oblique maculae (Fig. 190) (that resembles the primitive condition). Sterna II-VIII, besides medioanterior and medioposterior sigilla, have additional pair of sigilla located behind-mediad of the medioposterior sigilla (Fig. 191) (in species examined all three pairs of sternal sigilla are noncolored and poorly visible). Presence of additional muscles on abdominal sterna testifies about its secondarily elongation.

Characters of unclear phylogenetic status (non-unique apomorphies).

(4) Tarsus of middle and hind leg of imago and subimago has only 2 apical spines: only $2^{\text {nd }}$ and $3^{\text {rd }}$ tarsomeres are spinebearing; $4^{\text {th }}$ tarsomere (penultimate, with stretched apicalventral angle) lacks apical-ventral spine (Fig. 185). Fore tarsus of female also has 2 apical spines [see Jubabaetis/fg1 (2)].

(5) Imago and subimago of both species examined at rest keep their wings spread laterally (Fig. 201) (unlike all other Acentrella/fg1, which keep their wings raised up, as most mayflies); wings of both species have crossveins darkened (Figs 198, 201). Adults of other species are unknown, so it is unclear if these characters belong to all Platybaetis, or to certain species only.

DISTRIBUTION. Oriental Region.

SPECIES COMPOSITION. 8 species: 1 species in Nepal - uenoi Müller-Liebenau, 1980 [Platybaetis]; 1 species in Indochina (Vietnam and western Malaysia) - bishopi Müller-Liebenau, 1980 [Platybaetis]; 2 species in Borneo (Malaysia) — probus Müller-Liebenau, 1984 [Platybaetis] (see below) and sp. (see below); 1 species in Philippines edmundsi Müller-Liebenau, 1980 [Platybaetis]; 3 species in
Sulawesi - sulawesiensis Tong \& Dudgeon, 1999 [Platybaetis], wallacei Tong \& Dudgeon, 1999 [Platybaetis] and mamasae sp.n. [Platybaetis] (Table 3). Species examined are reviewed below.

REMARK. Species described as Platybaetis gagadjuensis Suter, 2001 from Australia, does not belong to Platybaetis: its shape of labial palp is different from that of Acentrella/fg1; tarsus has no subapical seta characteristic for Jubabaetis/g1; claw has one large seta, which is never found in Acentrella/fg1.

\section{C.1.2.2.3-1. Platybaetis/g(1) mamasae sp.n. [Platybaetis]}

(Figs 177-187, 189-201)

Systematic position: Acentrella/fg1—Jubabaetis/g1-g2Platybaetis.

Original binomen: Platybaetis mamasae Kluge \& Novikova, sp.n.

Possible binomina:

- Platybaetis mamasae;

- Jubabaetis (Platybaetis) mamasae;

- Acentrella (Platybaetis) mamasae;

- Baetis (Platybaetis) mamasae;

- Baetis (Jubabaetis) mamasae

- Baetis (Acentrella) mamasae.

MATERIAL Holotype: L-S-IO', INDONESIA, Sulawesi, tributary of river Mamasa $5 \mathrm{~km}$ W Mamasa, 26.VIII.2009, coll. N. Kluge \& L. Sheyko, specimen [XV](16)B. Paratypes: the same locality, 15-27.VIII.2009: 4 L-S ${ }^{7}, 1$ L-S , 59 larvae.

Larva. Cuticular COloration: Dorsal surface, including head capsule, pronotum, mesonotum, metanotum, thoracic pleura, dorsal (morphologically anterior) surfaces of femora and abdominal terga, has cuticular pigmentation in a form of brown marks and lighter blanks, partly diffusive, partly distinctly outlined. Occipit between oculi has paired

Table 3. Selected larval characters of known species of Platybaetis Таблица 3. Некоторые личиночные признаки известных видов Platybaetis

\begin{tabular}{|c|c|c|c|c|c|c|c|c|c|}
\hline 1 & 2 & 3 & 4 & 5 & 6 & 7 & 8 & 9 & 10 \\
\hline species & 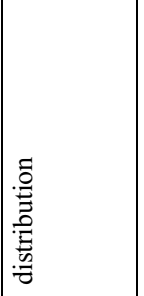 & 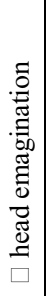 & 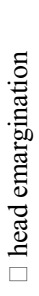 & 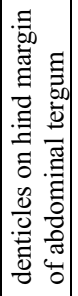 & 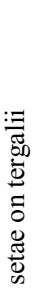 & 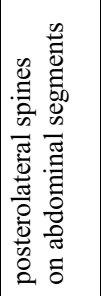 & 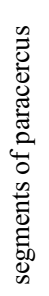 & 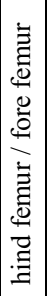 & 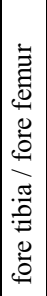 \\
\hline uenoi [Platybaetis] & Himalaya & $?$ & $?$ & $?$ & $?$ & $?$ & 5 & $?$ & $?$ \\
\hline bishopi [Platybaetis] & Indochina & $?$ & $?$ & UUU & - & - & 1 & $?$ & $?$ \\
\hline probus $[$ Platybaetis $]{ }^{*}$ & Borneo & + & + & TTT & - & VIII-IX & 9 & 0.8 & 0.6 \\
\hline sp. B2 * & Borneo & + & + & VVV & - & II-IX & 9 & 0.8 & 0.6 \\
\hline edmundsi [Platybaetis] & Philippines & $?$ & + & VVV & - & - & $6-7$ & $?$ & $?$ \\
\hline sulawesiensis [Platybaetis] & Sulawesi & - & + & VVV & + & $?$ & 1 & $?$ & $?$ \\
\hline wallacei $[\text { Platybaetis }]^{*}$ & Sulawesi & - & + & UUU & - & - & 1 & 1 & 0.8 \\
\hline mamasae sp.n. [Platybaetis] * & Sulawesi & - & + & IIIIII & - & - & 1 & 1 & 1 \\
\hline
\end{tabular}

Table legend. 1 - species (species examined are indicated by asterisks); 2 — distribution; 3 and $\mathbf{4}$ (emargination on hind margin of head in male and female) _ " "+" present (Fig. 180); "-" absent (Fig. 179); 5 (denticles on hind margin of abdominal tergum) — "UUU" blunt; "VVV" pointed; "TTT" spine-like; "IIIIII" palisade (Fig. 196); 6 (setae on tergalii) _ " "+" present; "_" absent; 7 _ abdominal segments which bear posterolateral spines; 8 - number of segments of larval paracercus; 9 - ratio of hind femur length to fore femur length; $\mathbf{1 0}$ ratio of fore tibia length to fore femur length.

Пояснение к таблице. 1 - вид (исследованные виды отмечены звездочками); 2 - распространение; 3 и 4 (вырезка на заднем крае головы у самца и самки) _ “+” имеется (рис. 180); “-” отсутствует (рис. 179); 5 (зубчики на заднем крае тергита брюшка) "UUU” тупые; "VVV” заостренные; “ТТT” шиповидные; “ІІІІІ” палисадные (рис. 196); 6 (щетинки на тергалиях) — “+” имеются; “_” отсутствуют; 7 - сегменты брюшка, несущие постеролатеральные шипы; 8 - число члеников парацерка; 9 - отношение длины заднего бедра к длине переднего бедра; 10 - отношение длины передней голени к длине переднего бедра. 
contrasting dark sigilla on lighter background. Pronotum and mesonotum have characteristic color pattern (Fig. 200). Abdominal terga have diffusive brown marks and light blanks; medioanterior and medioposterior sigilla brown; medioanterior sigilla oblique drop-like; medioposterior sigilla round (Figs 190, 199). Each femur light, with a short (1/4 of femur length) dark longitudinal stripe parallel to outer margin and with large diffusive macula in median part. Ventral surface, including thoracic and abdominal sterna and ventral (morphologically posterior) surfaces of femora, has cuticle colorless. Cuticle of cerci light, unicolor.
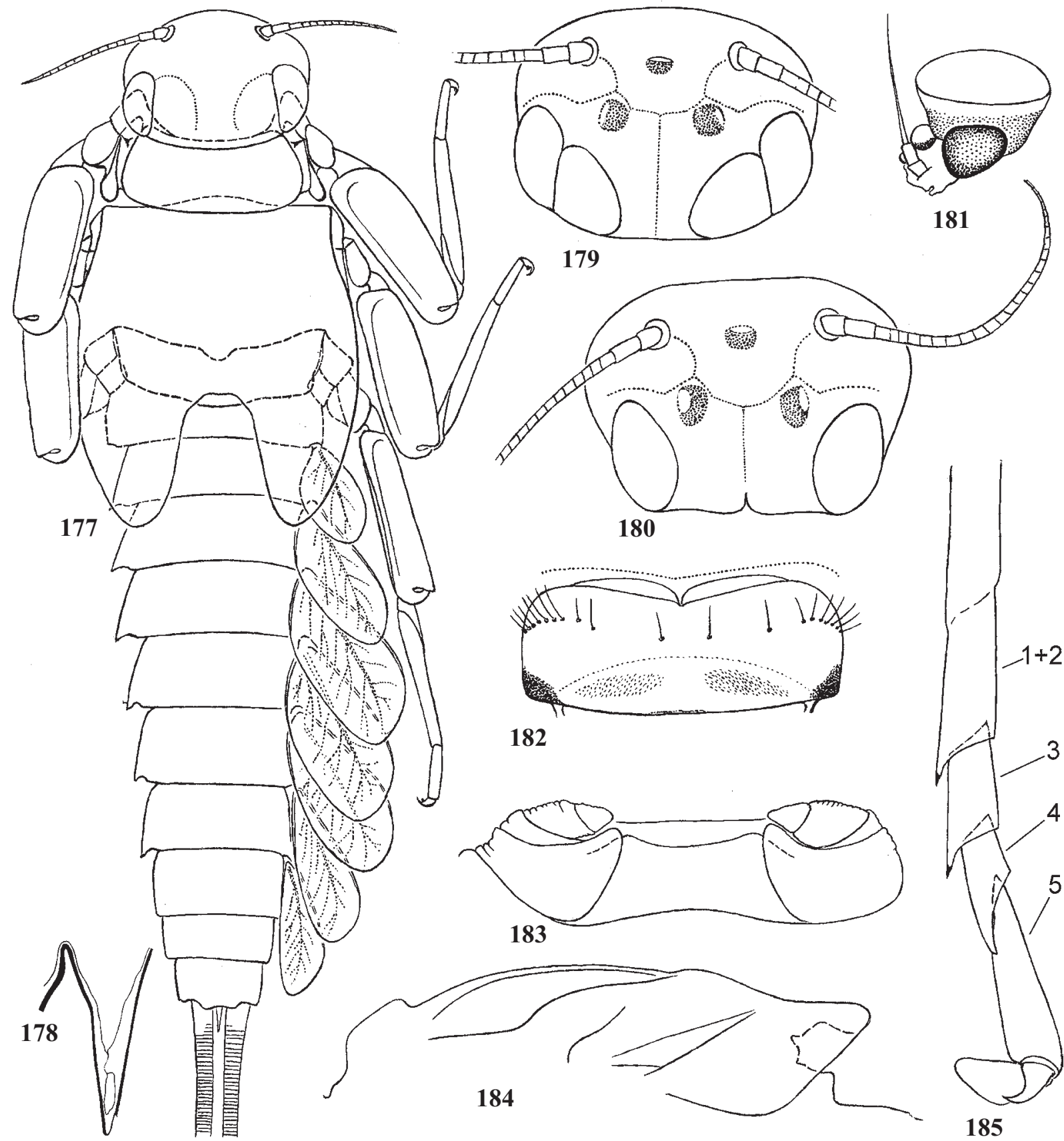

Figs 177-185. Platybaetis/g(1) mamasae sp.n. [Platybaetis]: 177 - mature male larva, dorsal view; 178 - developing of subimaginal paracercus under larval cuticle; 179 — head of mature male larva; 180 — head of mature female larva; 181 - head of male imago, lateral view (holotype); 182 - labrum; 183 — buds of subimaginal gonostyli folded under larval cuticle; 184 — imaginal mesonotum, lateral view (holotype); 185 - tarsus of middle leg of male imago (holotype)'; $\mathbf{1 + 2}$ - completely fused $1^{\text {st }}$ and $2^{\text {nd }}$ tarsomeres; $\mathbf{3}, \mathbf{4}, \mathbf{5}-3^{\text {td }}, 4^{\text {th }}$ and $5^{\text {th }}$ tarsomeres.

Рис. 177-185. Platybaetis/g(1) mamasae sp.n. [Platybaetis]: 177 — зрелая личинка самца, дорсально; 178 — развитие субимагинального парацерка под кутикулой личинки; 179 - голова зрелой личинки самца; 180 — голова зрелой личинки самки; 181 - голова самца имаго, латерально (голотип); 182 — верхняя губа; 183 - зачатки субимагинальных гоностилей, сложенные под личиночной кутикулой; 184 - имагинальный мезонотум, латерально (голотип); 185 - лапка средней ноги самца имаго (голотип);

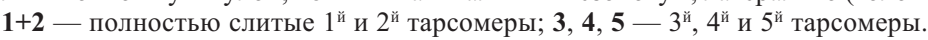



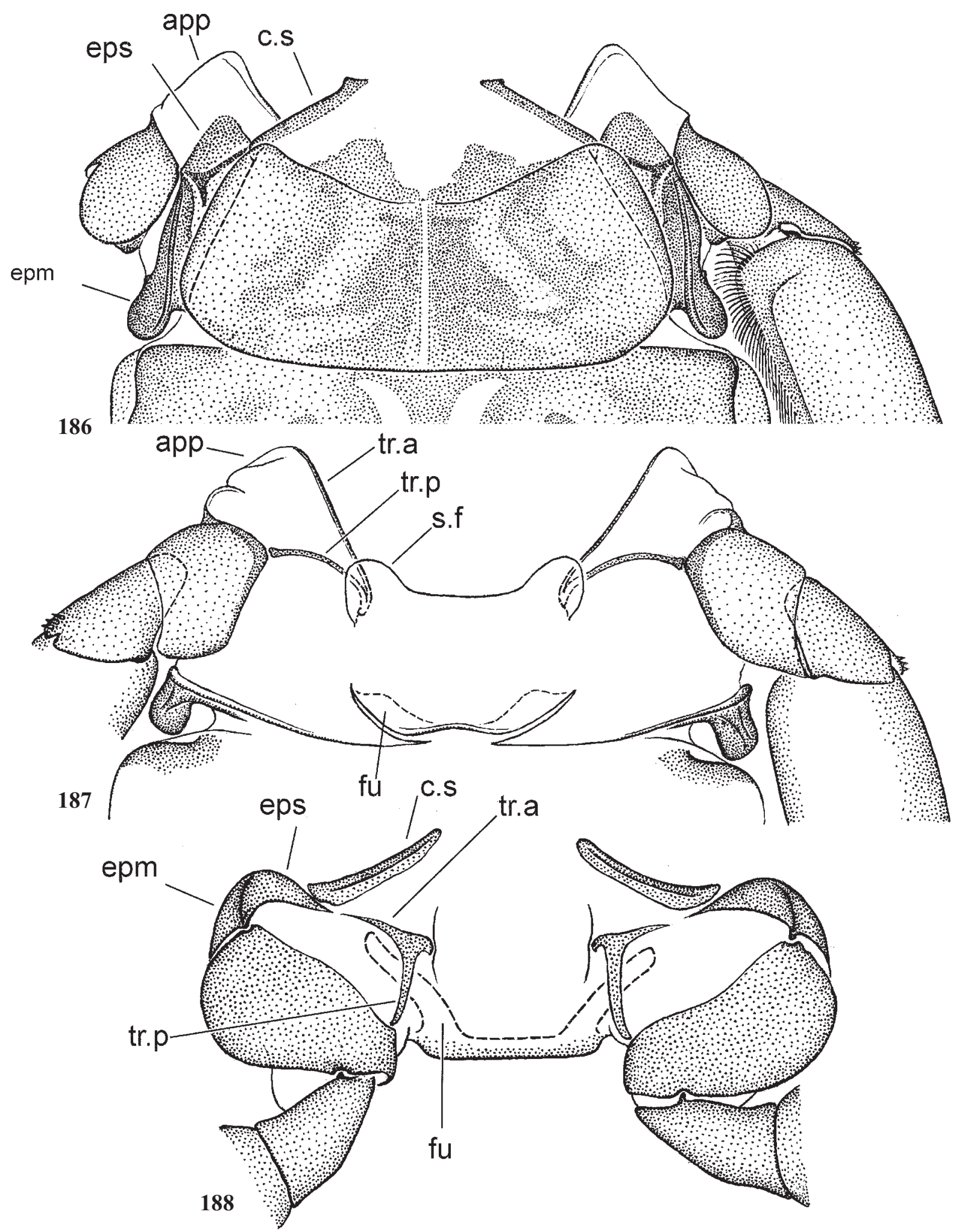

Figs 186-188. Structure of larval prothorax: 186 — Platybaetis/g(1) mamasae sp.n. [Platybaetis], dorsal view; 187 - the same, ventral view; 188 - ventral view of prothorax of lapponica [Acentrella], as example of non-modified structure; app — anterior prothoracic projection; c.s - cervical sclerite; epm - epimeron; eps - episternum; fu — sternal apodeme (furca); tr.a — anterior stripe-like sclerite of trochantine; tr.b - posterior stripe-like sclerite of trochantine; s.f — sternal flap.

Рис. 186-188. Строение переднегруди личинки: 186 - Platybaetis/g(1) mamasae sp.n. [Platybaetis], дорсально; 187 — то же, вентрально; 188 - вентральный вид переднегруди lapponica [Acentrella] как пример немодифицированного строения; app передний выступ переднегруди; c.s — шейный склерит; epm — эпимерон; eps — эпистернум; fu — стернальная аподема (фурка); tr.a - передний полосовидный склерит трохантина; tr.b - задний полосовидный склерит трохантина; s.f - стернальная лопасть. 

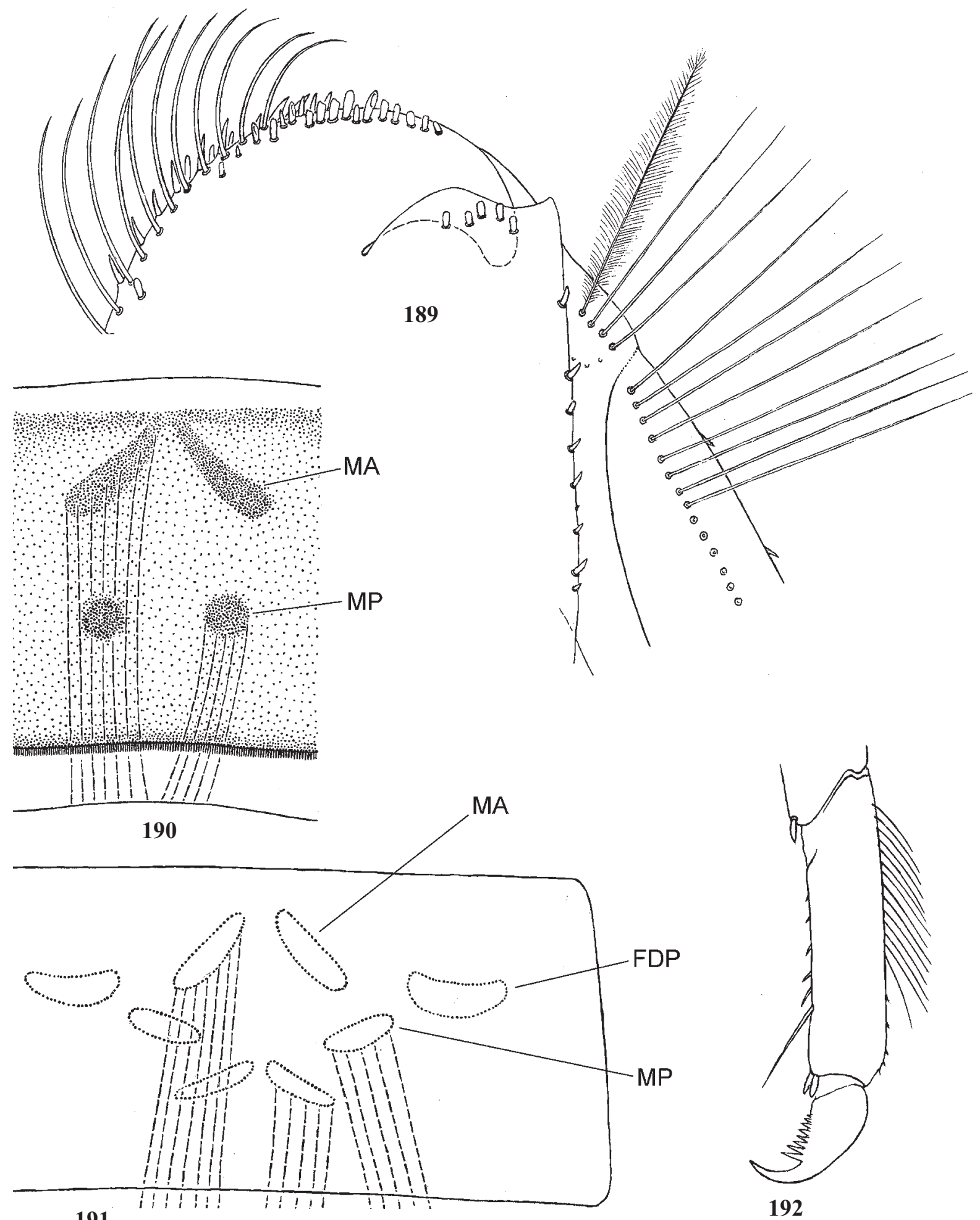

191

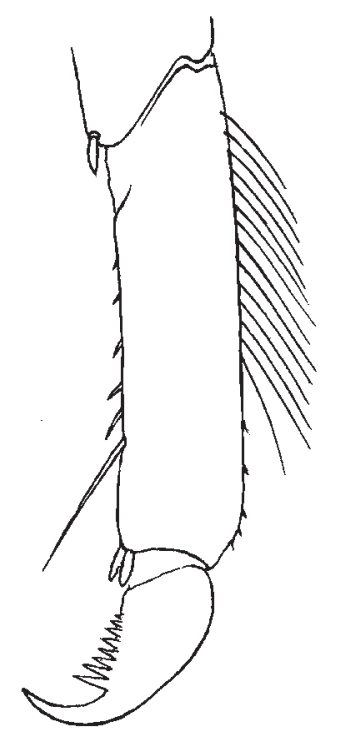

192

Figs 189-192. Platybaetis/g(1) mamasae sp.n. [Platybaetis], larva: 189 - articulation of femur and tibia, dorsal view (one tibial seta shown with fine processes, which are thicker than in reality; processes of other setae not shown); 190 — median part of larval tergum V and anterior margin of tergum VI (two muscles shown by interrupted lines); 191 - median part of larval sternum V (three muscles shown by interrupted lines); 192 — tarsus and claw. Abbreviations as in Fig. 99.

Рис. 189-192. Platybaetis/g(1) mamasae sp.n. [Platybaetis], личинка: 189 - сочленение бедра и голени, дорсально (на одной щетинке голени тонкие отростки показаны более толстыми, чем в действительности; отростки на других щетинках не показаны); 190 - медиальная часть V тергита и передний край VI тергита (две мышцы показаны прерывистыми линиями); 191 - медиальная часть V стернита брюшка (три мышцы показаны прерывистыми линиями); 192 — лапка и коготок. Сокращения как на рис. 99. 

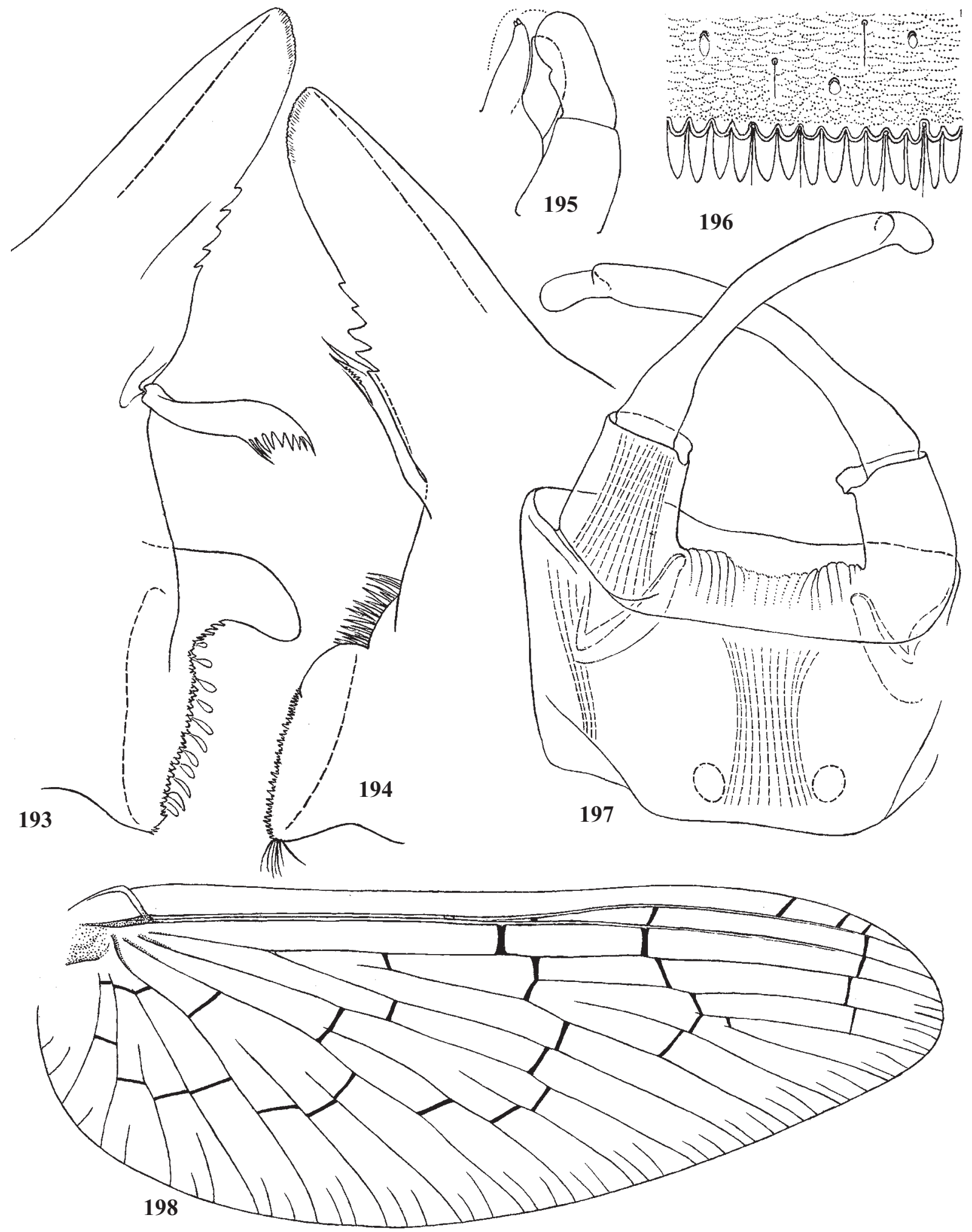

Figs 193-198. Platybaetis/g(1) mamasae sp.n. [Platybaetis]: 193-194 — left and right mandibles; 195 — half of labium; 196 - posterior margin of larval abdominal tergum VI (holotype); 197 - genitals of male imago, ventral view (right gonostylar muscle and right gonovectal muscle not shown; for explanation see Fig. 3) (holotype); 198 - fore wing.

Рис. 193-198. Platybaetis/g(1) mamasae sp.n. [Platybaetis]: 193-194 - левая и правая мандибулы; 195 — половина нижней губы; 196 - задний край VI тергита брюшка личинки (голотип); 197 — гениталии самца имаго, вентрально (правая гоностилярная мышца и мышца правого гоновектиса не показаны; объяснение на рис. 3) (голотип); 198 - переднее крыло. 
HYPODERMAL COLORATION: Hypoderm either colorless, or with pale markings invisible through cuticle. Fore protoptera of immature larva have hypoderm light with all veins lighter: crossveins widened, but not darkened (unlike darkened and widened in imago).

SHAPE AND SETATION: Head wide and flattened; frons not projected above clypeus, has no dense setation. Occipit of male has no incision (Fig. 179), in female has deep incision (Fig. 180) Scapus of antenna symmetric (Figs 179, 180). Labrum short and wide, with length 3 times less than width (Fig. 182). Mandibles blade-like: incisor very long, nearly parallel-sided, without large denticles, semicylindrical, at apex obliquely tapered and round- ed; kinetodontium reduced to 5 small denticles, which lie nearly on the same line with median margin of incisor (Figs 193, 194) (in most specimens incisor is more or less shortened, being wore out, so only new-molted specimens should be examined). Labium has paraglossal muscle oblique and fan-like; $2^{\text {nd }}$ palpomere has muscle (as in Fig. 152). $2^{\text {nd }}$ palpomere has length exceeding width, $3^{\text {rd }}$ palpomere has length equal to width (Fig. 195). Thoracic sterna have no prominent subfurcal protuberances. Hind protoptera either reduced to very small vestiges (smaller than in Fig. 125), or completely absent; they can be present and absent on left and right sides of the same specimen. Legs thick. All legs have equal length of femora and equal length of

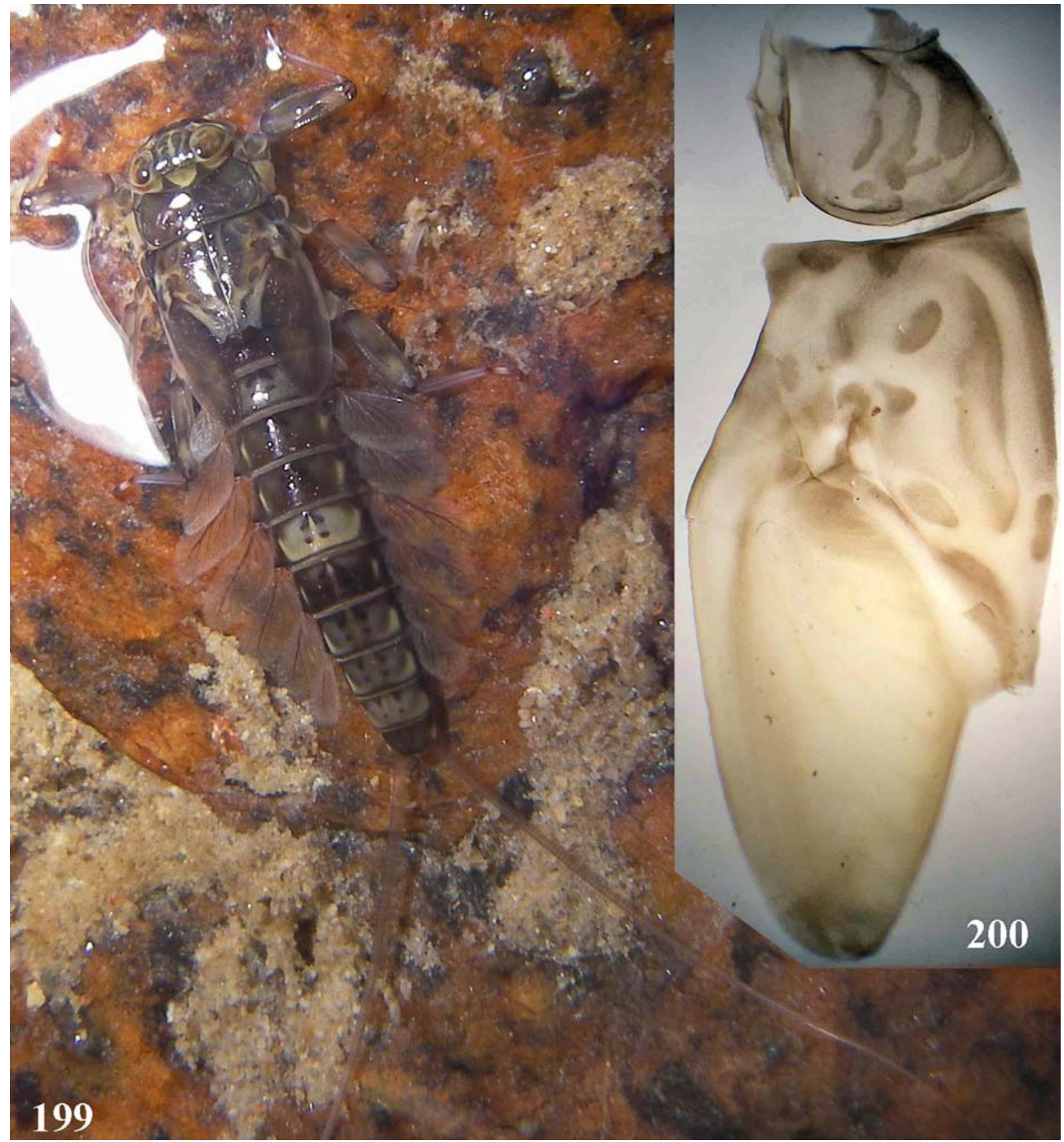

Figs 199-200. Platybaetis/g(1) mamasae sp.n. [Platybaetis], larva: 199 — natural position on wet stone; 200 - exuviae of left part of pronotum and mesonotum.

Рис. 199-200. Platybaetis/g(1) mamasae sp.n. [Platybaetis], личинка: 199 - естественное положение на мокром камне; 200 экзувий левой половины пронотума и мезонотума. 
tibiae; on all legs length of tibia equal to length of femur; tarsus about 3.5 times shorter than tibia; on fore leg of male larva tarsus slightly longer, about 3 times shorter than tibia (Fig. 177). Femur width about 0.3 of femur length; on fore leg femur widest in proximal part, on other legs femur equally wide at most its length. Tibia width $0.08-0.1$ of tibia length. Patella occupies less than $1 / 2$ of inner tibial margin. Long setae forming the regular row on external margin of femur, have length about 0.4 of femur width; each seta bears fine long processes. Besides them, external margin of femur bears sparse, short stout spinelike setae; on apical margin of femur short spine-like setae are very dense (Fig. 189) (unlike other species). Setae forming the regular row on dorsal margin of tibia [see Acentrella/fg1 (3)] long, their length exceeds tibia width; each seta bears fine long processes; second (external) row of long setae absent. Setae forming the row on dorsal margin of tarsus, similar to that on tibia, but somewhat smaller; inner margin of tarsus bears a row of short stout setae, terminated by a long subapical seta (characteristic for Jubabaetis/g2) (Fig. 192). Claw has 8 denticles; subapical setae vestigial. All abdominal segments lack posterolateral spines (Fig. 177). Abdominal terga not wide and much longer than in most Acentrella/fg1 other than Platybaetis: width of spread abdominal tergum II between tergalii bases 4 times exceeds its length; width of spread abdominal tergum III between tergalii bases 3 times exceeds its length. Abdominal terga lack long scales, have very small sparse scales only; denticles on posterior margins of terga palisade: unusually long, dense and regular, with tips pointed or blunt (Fig. 196). On abdominal sterna II-IX paired fields of dentate protuberances transverse, narrow, locate only laterad of medioposterior sigilla (Fig. 191) Tergalii very large, spread laterally, tergalius I smaller than other
(Fig. 177) (the same in other Platybaetis). Vestige of paracercus short and one-segmented; in spite of this, subimaginal vestige of paracercus develops in it with wastes (Fig. 178). Cerci subequal to body length. Primary swimming setae developed: one or few setae on each proximalmost segment; 16-18 setae with pressed transverse bases on each middle segment; absent in distal parts of cerci.

Subimago and imago. At rest keep wings spread laterally. The same in wallacei [Platybaetis].

Subimago. Cuticular COLORATION. Most part of cuticle colorless; wing articulation and basal plate darkened with brownish; thoracic pleura with a few brown markings, the largest of which a dark brown paired longitudinal stripe on junction of metanotum with metapleura. Wings light; in young subimago crossveins as light as longitudinal veins, later become dark brown as in imago. Cuticle of tibiae looks somewhat darkened, because its microtrichiae darker than microtrichiae on femora and body.

Hypodermal coloration. As in imago.

Imago, male. Head, thorax, abdomen, legs and caudalii light, at most yellowish. Turban eyes wide (Fig. 181), yellow, with stem brownish. Anteronotal protuberance flattened (Fig. 184), less prominent than in most Acentrella/fg1. Thorax yellow, with a few small diffusive brownish maculae on pleura. All legs pale yellowish; femur with large, diffusive, orange macula near apex; last tarsal segment either as pale as others, or tinged with light brownish. On fore leg femur 8/7 longer than in larva and subimago; tibia 1.7 of femur length; tarsus shorter than tibia, 1.2 of femur length. On middle and hind legs femur has length equal to larval and subimaginal; tibia 1.4-1.5 of femur length; tarsus three times shorter than tibia, 0.5 of femur length. On

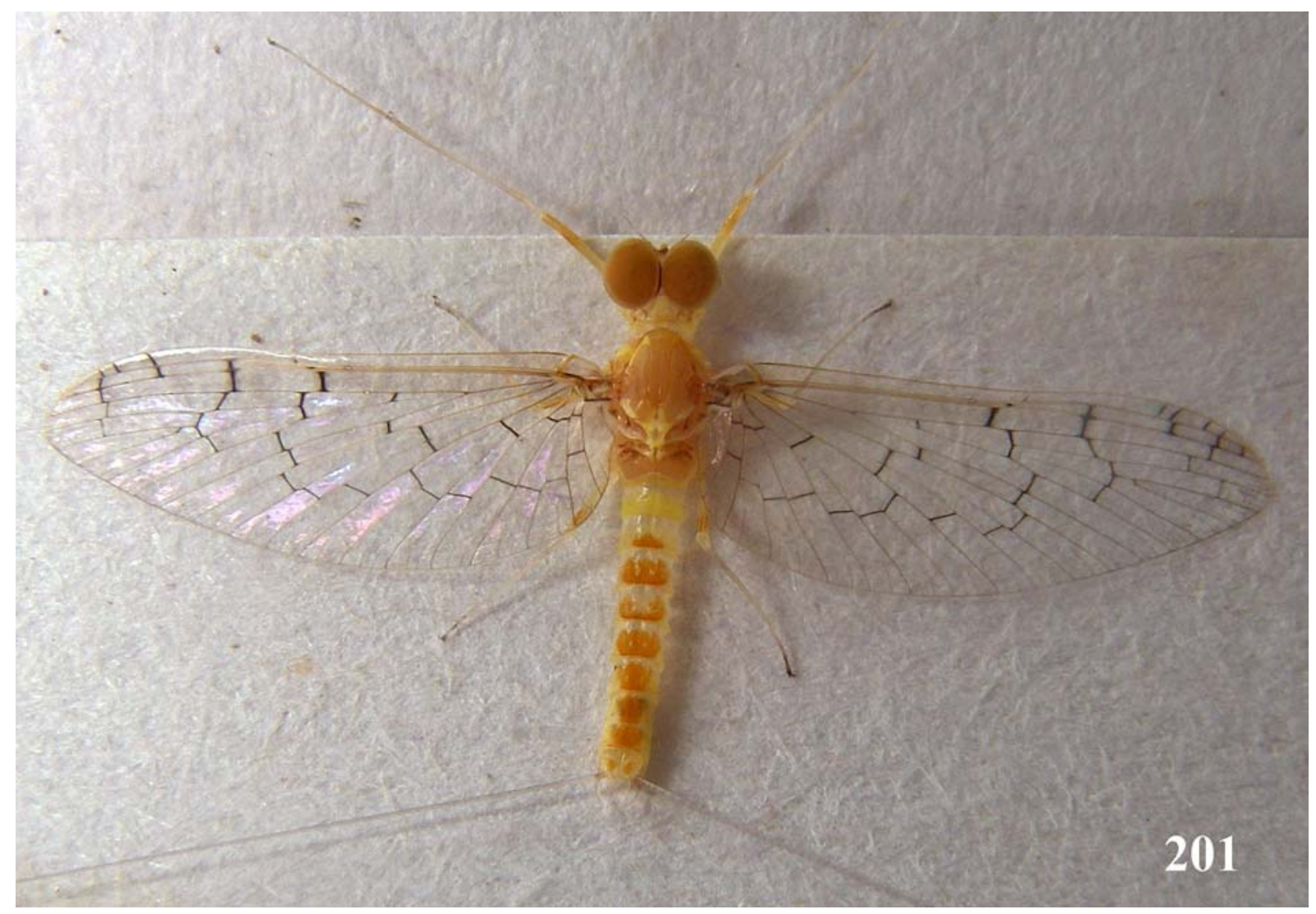

Fig. 201. Platybaetis/g(1) mamasae sp.n. [Platybaetis], male imago at rest (holotype).

Pис. 201. Platybaetis/g(1) mamasae sp.n. [Platybaetis], самец имаго в покое (голотип). 
middle and hind legs tarsus has 2 apical spines: $1^{\text {st }}+2^{\text {nd }}$ and $3^{\text {rd }}$ tarsomeres are spine-bearing, while $4^{\text {th }}$ tarsomere (penultimate, with stretched apical-ventral angle) lacks apical-ventral spine (Fig. 185) [see Platybaetis (3)]. Fore wing has base light brownish; longitudinal veins yellowish; bulla colorless; crossveins widened and dark brown; pterostigma whitish, with a few thickened dark brown crossveins (Fig. 198, 201). Abdomen at most part very pale yellowish, nearly colorless; each tergum IIIIX has large orange-yellow macula medially; on tergum 3 this macula smaller and occupies less than $1 / 2$ of tergum length; on each tergum IV-IX this macula large and occupies most part of tergum length (Fig. 201). Genitals colorless. Styliger wide; unistyligers long, cylindrical, with inner-distal margin widened; $1^{\text {st }}$ segment of gonostylus conic; $2^{\text {nd }}$ segment long and parallelsided, not widened apically; $3^{\text {rd }}$ segment short; penial bridge non-sclerotized, lacks projections; gonovectes small, colorless and poorly visible; styligeral muscle relatively wide (Fig. 197). Cerci uniformly pale.

Imago, female. Unknown. Judging by female subimago, has coloration similar to male. On fore leg tarsus has 2 apical spines: $2^{\text {nd }}$ and $3^{\text {rd }}$ tarsomeres are spine-bearing, while $4^{\text {th }}$ tarsomere (penultimate, with stretched apical-ventral angle) lacks apical-ventral spine; on middle and hind legs tarsus also has 2 apical spines (as in male, Fig. 185) [see Platybaetis (3)].

Egg. Unknown.

Dimension. Fore wing length $9 \mathrm{~mm}$.

COMPARISON. Male imago the new species differs from wallacei $[$ Platybaetis] by yellow turban eyes and absence of distal projection on unistyliger (Fig. 197). Larva differs from all Platybaetis by palisade denticles on posterior margins of abdominal terga (Fig. 196) and blade-like mandibles (Figs 193-194); from species examined differs also by dense short stout setae on tips of femora (Fig. 198).

\section{C.1.2.2.3-2. Platybaetis/g(1) wallacei [Platybaetis]} (Figs 202-205)

Systematic position: Acentrella/fg1-Jubabaetis/g1-g2Platybaetis.

Original binomen: Platybaetis wallacei Tong \& Dudgeon, 1999. Possible binomina:

- Platybaetis wallacei;
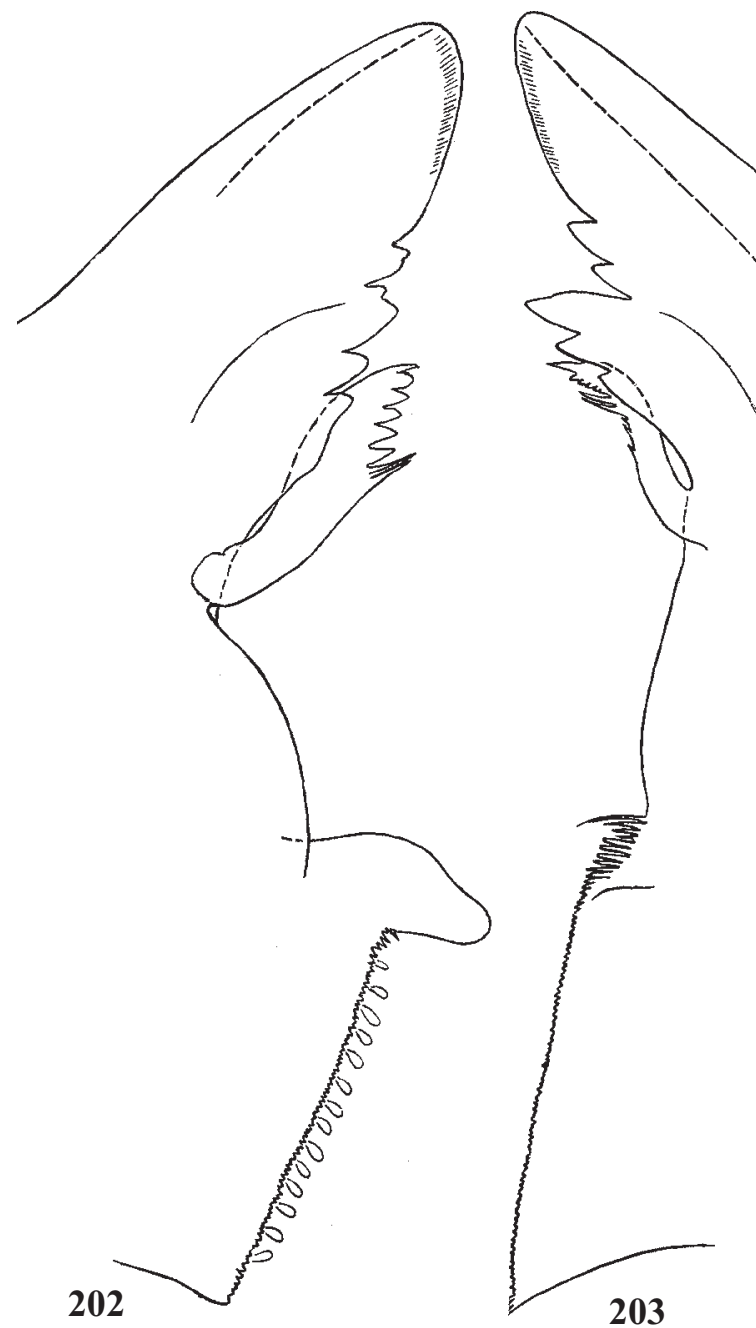
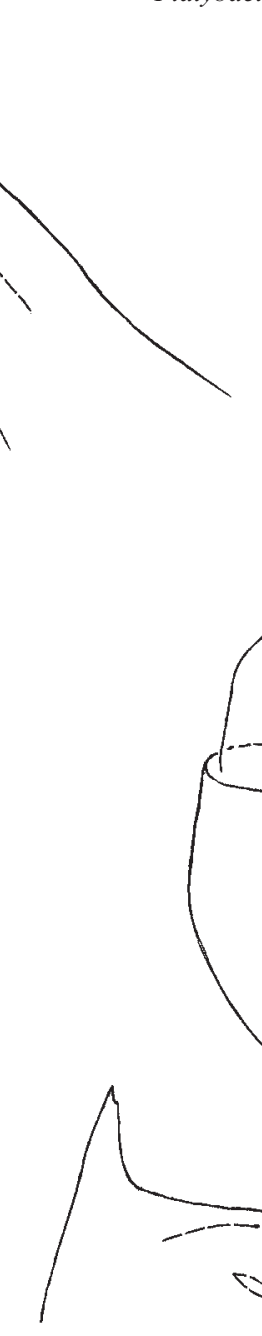
- Jubabaetis (Platybaetis) wallacei;

- Acentrella (Platybaetis) wallacei;

- Baetis (Platybaetis) wallacei;

- Baetis (Jubabaetis) wallacei;

- Baetis (Acentrella) wallacei.

REFERENCE: Platybaetis wallacei Tong \& Dudgeon, 1999 (larva)

MATERIAL. INDONESIA, Sulawesi, tributary of river Mamasa $5 \mathrm{~km} \mathrm{~W}$ Mamasa, 15-27.VIII.2009, coll. N. Kluge \& L. Sheyko: 3 L-S-I $\sigma^{\top}, 2$ L-S $\sigma^{\top}, 2$ L-S +47 larvae.

Larva. Described by Tong \& Gudgeon [1999]. Differs from $P$. mamasae by the following characters: Incisor of mandible not so long; kinetodontium projected, especially on right mandible (Figs 202-203). Labial palp shorter (Fig. 204). Legs thicker and shorter: femur width about 0.35 of femur length; tibia shorter than femur, about 0.9 of femur length, tibia width more than 0.1 of tibia length. Apex of femur bears only a few short spine-like setae. Row of long setae on outer side of tarsus irregular and expressed at proximal part of tarsus only. Denticles on posterior margins of terga shorter, with length subequal to width.

Imago, male. Very similar to mamasae $[P$.]; differs by the following characters: Turban eyes light orange, with stem reddish. Each unistyliger on median-dorsal side of its distal margin bears a flat projection, directed distally (Fig. 205).

\section{C.1.2.2.3-3. Platybaetis/g(1) probus [Platybaetis]}

(Fig. 206)

Systematic position: Acentrella/fg1-Jubabaetis/g1-g2Platybaetis.

Original binomen: Platybaetis probus Müller-Liebenau, 1984.

Possible binomina:

- Platybaetis probus;

- Jubabaetis (Platybaetis) probus.;

- Acentrella (Platybaetis) proba;

- Baetis (Platybaetis) probus;

- Baetis (Jubabaetis) probus;

- Baetis (Acentrella) probus.

REFERENCE: Platybaetis probus Müller-Liebenau, 1984 (larva).

MATERIAL. MALAYSIA, Borneo, Sabah: Liwangu river, SE of Kinabalu national park, 14-15.VIII.1972, coll. W.L. \& J.G. Peters: 1 male larva; Karagasan, Ranau, 6.IX.1994, coll. S.C. Kang: 4 larvae.

Larva. Well differs from all other species by unusual spines on hind margins of abdominal terga [Müller-Liebenau, 1984: Fig.1, 12]. Some other characters are given in Table 3.

\section{C.1.2.2.3-4. Platybaetis/g(1) sp. B2}

Systematic position: Acentrella/fg1-Jubabaetis/g1-g2Platybaetis.

MATERIAL. MALAYSIA, Borneo, Sabah, Karagasan, Ranau, 6.IX.1994, coll. S.C. Kang: 4 larvae.

Larva. Differs from other species examined by presence of posterolateral spines on all abdominal segments II-IX and by combination of other characters (Table 3 ).

ACKNOWLEDGEMENT. This work was supported by The Council for Grants from the President of Russian Federation and for State Support of Leading Scientific Schools (grant 3332.2010.4)

\section{References}

Alba-Tercedor J. \& McCafferty W.P. 2000. Acentrella feropagus, new species (Ephemeroptera: Baetidae): formal new name for North American A. lapponica sensu Morihara and McCafferty // Entomological News. Vol.111. P.137-139.

Bengtsson S. 1912. Neue Ephemeriden aus Schweden // Entomologisk Tidskrift. Bd.33. S.107-117.

Bogoescu C.D. 1931. Une nouvelle espèce d'Acentrella Bgtss. (Éphémétoptère) Acentrella sinaica n.sp. // Bulletin de la Section Scientifique de l'Académie Roumaine Vol.14. P.197-202.
Bogoescu C. 1951. Dona specii noi de ephemeroptere in R.P.R. [Deux nouvelles espèces d'Éphémétoptères dans la R.P.R.] // Comun. Acad. Repub. Rom. Vol.1. N.8. P.781-786.

Bogoescu C. 1958. Fauna Republicii Socialiste România. Volume VII. Insecta (I). Fasc 3. Ephemeroptera // Buccuresti, Academia Republicii Socialiste România. 187p.

Bogoescu C., Tabacaru I. 1957. Etude comparée des nymphes d'Acentrella et de Pseudocloeon. Considérations phylogénétiques concernant la famille Baetidae (Ephemeroptera) // Beiträge zur Entomologie. T.7. P.483-492.

Braasch D. \& Soldán T. 1983. Baetidae in Mittelasien III (Ephemeroptera) // Entomologische Nachrichten und Berichte. Bd.27. Nr.6. S.266-271.

Eaton A.E. 1883-1888. A revisional monograph of recent Ephemeridae or mayflies // Transactions of the Linnean Society of London. (2). Vol.3. P.1-352, 65 pl.

Gillies M.T. 1991.A diphyletic origin for the two-tailed baetid nymphs occurring in East African stony streams with a description of the new genus and species Tanzaniella spinosa gen.nov. sp.nov. // J. Alba-Tercedor \& A. Sanchez-Ertega (eds). Overview and strategies of Ephemeroptera and Plecoptera (Proc. $6^{\text {th }}$ Int. Congf. Ephemeroptera \& 10th Int. Symp. Plecoptera, 24-30 July 1989, Granada, Spain). Sandhill Crane Press. P.175-187.

Gose K. 1964. Description of some mayfly nymphs from Congo // Kontyû. Vol.32. No.1. P.55-64.

Grandi M. 1948. Contributi allo studio degli "Efemeroidei" italiani. X. Baetis atrebatinus Eaton // Bollettino dell'Istituto di Entomologia della Università di Bologna. Vol.17. P.62-75.

Grandi M. 1956. Contributi allo studio degli Efemeroidei italiani. XXI. Intorno ai generi Acentrella Bgtss. e Baetis Leach // Bollettino dell'Istituto di Entomologia della Università di Bologna (1957). Vol.22. P.119-124.

Grandi M. 1960a. Ephemeroidea // Fauna d'Italia. Bologna. 472 p.

Grandi M. 1960b. Contributi allo studio degli Efemeroidei italiani. XXIII. Gli organi genitali esterni maschili degli Efemeroidei // Bollettino dell'Istituto di Entomologia della Università di Bologna. Vol.24. P.67-120.

Grandi M. 1960c. Particolare contituzione degli organi genitali esterni nei maschi dei Betidi (Insecta - Ephemeroidea) // Accademia Nazionale dei Lincei (Classe di Scienze Fisiche, Matematiche e Naturali). (8). Vol.28. P.86-91.

Jacob U. (1990)1991. Ephemeroptera: Zur Systematic der europäischen Baetidae aus Gattungsbene // Verhandlungen der Westdeutschen Entomologischen Tagung 1990. S.271-290.

Jacob U. 2003. Baetis Leach 1815, sensu stricto oder sensu lato. Ein Beitrag zum Gattungskonzept auf der Grundlage von Artengruppen mit Bestimmungsschlüsseln // Lauterbornia. Bd.47. S.59-129.

Jacobus L.M. \& McCafferty W.P. 2006. A new species of Acentrella Bengtsson (Ephemeroptera: Baetidae) from Great Smoky Mountains National Park, USA // Aquatic Insects. Vol.28. P.101-111.

Kazlauskas R.S. 1963. [New and little-known may flies (Ephemeroptera) from the USSR] // [Entomologicheskoe Obozrenie $=$ Revue d'Entomologie de l'URSS]. Vol.42. No.3. P.582-592 (in Russian).http://www.famu.org/mayfly/pubs/pub_k/ pubkazlauskasr1963p582.pdfhttp://www.famu.org/mayfly/ pubs/pub_j/pubjacobus12006p101.pdf

Kazlauskas R.S. 1972. Neues über das System der Eintagsfliegen der Familie Baetidae (Ephemeroptera) // Proc. XIII Int. Congr. Entomol. Moscow, 2-9 August 1968. Vol.3. P.337-338.

Kazlauskas R.S. 1977. [Ephemeroptera] // L.A. Kutikova \& Ya.I. Starobogotov (eds.). Key to freshwater invertebrates of the European part of the USSR Leningrad: Gidrometeoizdat. P.288303 [in Russian].

Klapálek F. 1905. Plecopteren und Ephemeriden aus Java, gesammelt von Prof. K. Kraepelin 1904 // Mitteilungen aus dem Naturhistorischen Museum in Hamburg. Bd.22. P.103-107.

Kluge N.J. 1980. [To the knowledge of mayflies (Ephemeroptera) of Taimyr National District] // [Entomologicheskoe Obozrenie $=$ Revue d'Entomologie de 1'URSS]. Vol.59. No.3. P.561-579 [in Russian].

Kluge N.J. 1981. [A new species of the genus Baetis (Ephemeroptera, Baetidae) from Kazakhstan] // [Zoologicheskiy Zhurnal]. Vol.60. No.9. P.1418-1419 [in Russian].

Kluge N.J. 1983. [New and little known mayflies of the family Baetidae (Ephemeroptera) from Primorye Territiry] // [Entomologicheskoe Obozrenie $=$ Revue d'Entomologie de 1'URSS]. Vol.61. No.1. P. 65-79 [in Russian]. 
Kluge N.J. 1995. [A catalogue of the type-specimens in the collection of the Zoological Institute, Russian Academy of Sciences. Insecta, Ephemeroptera] . St.Petersburg: Zoological Institute Rus. Acad. Sci. 52 p. [in Russian]. http://www.famu.org/mayfly/pubs/pub_k/pubklugen1995p1.pdf

Kluge N.J. 1997a. Classification and phylogeny of the Baetidae (Ephemeroptera) with description of the new species from the Upper Cretaceous resins of Taimyr // P. Landolt \& M. Sartori (eds.). Ephemeroptera \& Plecoptera. Biology-Ecology-Systematics (Proc. VIII Int. Conf. on Ephemeroptera and XII Int. Symposium on Plecoptera, August 1995, Losanne). Fribourg/ Switzerland: Mauron+ Tinguely \& Lacht SA. P.527-535.

Kluge N.J. 1997b. [Ephemeroptera] // S.J. Tsalolikhin (ed.). Key to frashwater invertebrates of Russia and adjacent lands. St.Petersburg. Vol.3. P.176-220 [in Russian].

Kluge N.J. 2000. [Modern systematics of insects. Part I. Principles of systematics of living organisms and general system of insects with classification of primary wingless and paleopterous insects]. St.-Petersburg: Lan'. 336 p. [in Russian]

Kluge N.J. 2004. The phylogenetic system of Ephemeroptera // Kluwer Academic Publishers. 456 p.

Kluge N.J. 2010. Circumscriptional names of higher taxa in Hexapoda. // Bionomina. No.1. P.15-55.

Kopelke J.-P. \& Müller-Liebenau I. 1982. Eistrukturen bei Ephemeroptera und deren Bedeutung für die Aufstellung von Artengruppen am Beispiel der europäischen Arten der Gattung Baetis Leach, 1815, (Insecta: Baetidae). Teil I: alpinus-, lutheri-, pavidus- und lapponicus-Gruppe // Gewässer und Abwässer. Bd.68/69. S.7-25.

Landa V. \& Soldán T. 1985. Phylogeny and higher classification of the order Ephemeroptera: a discussion from the comparative anatomical point of view // Academia - Studie CSAV (Czechoslovak Acad. Sci.). Vol.4. P.1-121.

Lugo-Ortiz C.R. \& McCafferty W.P. 1997. A new genus and redescriptions for African species previously placed in Acentrella (Ephemeroptera: Baetidae) // Proceedings of the Entomological Society of Washington. Vol.99. No.3. P.429-439.

Lugo-Ortiz C.R. \& McCafferty W.P. 1998. A new North American genus of Baetidae (Ephemeroptera) and key to Baetis complex genera // Entomological News. Vol.109. No.5. P.345-353.

McCafferty W. P. 2002. Gose's African ephemeroptera (Baetidae, Heptageniidae) // Entomological News. Vol.113. No.5. P.294-302.

McCafferty W.P. \& Barber-James H.M. 2005. Tanzaniops, replacement name for certain African Baetidae (Ephemeroptera) / Proceedings of the Entomological Society of Washington. Vol.197. P.238.

McCafferty W.P. \& Waltz R.D. \& Webb J.M. 2009. Acentrella nadineae, a new species of small minnow mayflies (Ephemeroptera: Baetidae) // Proceedings of the Entomological Society of Washington. Vol.111. No.1. P.12-17.

McCafferty W.P. \& Wigle M.J. \& Waltz R.D. 1994. Systematics and biology of Acentrella turbida (McDunnough) (Ephemeroptera: Baetidae) // Pan-Pacific Entomologist. Vol.70. No.4. P.301308.

Morihara D.K. \& McCafferty W.P. 1979. The Baetis larvae of North America (Ephemeroptera: Baetidae) // Transactions of the American Entomological Society. Vol.105. No.2. P.139-221.

Müller-Liebenau I. 1965. Revision der von Simon Bengtsson aufgestellten Baetis-Arten (Ephemeroptera) // Opuscula Entomologica. Vol.30. No.1-2. P 79-123.

Müller-Liebenau I. 1969. Revision der europäischen Arten der Gattung Baetis Leach, 1815 (Insecta, Ephemeroptera)// Gewässer und Abwasser. Bd.66/67. S.95-101.

Müller-Liebenau I. 1980. Jubabaetis gen.n. and Platybaetis gen.n., two new genera of the family Baetidae from the Oriental Region // J.F. Flannagan \& K.E. Marshall (eds.). Advances in Ephemeroptera Biology (Proc. $3^{\text {rd }}$ Int. Conf. Ephemeroptera, 4-10 July 1979 Winnipeg, Canada). N.Y.: Plenum. P.103-114.

Müller-Liebenau I. 1981. Review of the original material of the baetid genera Baetis and Pseudocloeon from the Sunda Islands and the Philippines described by G. Ulmer, with some general remarks (Insecta: Ephemeroptera) // Mitteilungen aus dem Hamburgischen Zoologischen Museum und Institut. Bd.78. S.197-208. http://www.famu.org/mayfly/pubs/pub_1/publugoc1997p429.pdf

Müller-Liebenau I. 1982. Five new species of Pseudocloeon Klapálek,
1905, (Fam. Baetidae) from the Oriental Region (Insecta, Ephemeroptera) with some general remarks on Pseudocloeon // Archiv für Hydrobiologie. Bd.95. Nr.1-4. S.283-295.

Müller-Liebenau I. 1984. Baetidae from Sabah (East Malaysia) (Ephemeroptera) // V. Landa, T. Soldán \& M. Tonner (eds.). Proceedings of the $4^{\text {th }}$ International Conference on Ephemeroptera. Ceské Budejovice: Institute of Entomology, Czechoslovak Academy of Sciences. P.85-99.

Müller-Liebenau I. 1985. Baetidae from Taiwan with remarks on Baetiella Ueno, 1931 (Insecta, Ephemeroptera) // Archiv für Hydrobiologie. Bd.104. Nr.1. S.93-110.

Novikova E.A. 1987. [Mayflies of the family Baetidae (Ephemeroptera) of the USSR fauna]. Dissertaciya na soiskanie uchenoi stepeni kandidata biologicheskikh nauk. Leningrad: Leningradskii Gosudarstvennyi Universitet. [Unpublished manuscript].

Novikova E.A. \& Kluge N.J. 1987. [Systematics of the genus Baetis (Ephemeroptera, Baetidae), with description of new species from Middle Asia] // Vestnik Zoologii. No.4. P.8-19 [in Russian].

Sroka P. \& Arnekliev J.V. 2010. Two new species of Acentrella Bengtsson, 1912 (Ephemeroptera, Baetidae) from Kazakhstan with notes on the Palaearctic fauna // Zootaxa. No.2693. P.1-20.

Sukackiene I.K. 1962. [Mayflies (Ephemeroptera) of the Angara River and its tributaries in the area of the Bratsk Hydro-electric Station Reservoir] // Lietuvos TSR Mokslu Akad. Darbai. (Ser.C). Vol.2. P.107-122 [in Russian]

Suter P.J. 2001. Platybaetis gagadjuensis, a new species from Northern Australia (Ephemeroptera: Baetidae) // E. Dominguez (ed.). Trends in research in Ephemeroptera and Plecoptera (Proc. IX Int. Conf. on Ephemeroptera \& XIII Int. Symp. on Plecoptera, 16-23 Aug. 1998, Tafi de Valle, Tucuman, Argentina). N.Y.: Kluwer Academic/Plenum Press. P.359-364.

Tong X.-L. \& Dudgeon D. 1999. Two new species of Platybaetis (Ephemeroptera, Baetidae) from Sulawesi, Indonesia // Entomological News. Vol.110. Nr.5. P.290-296.

Tshernova O.A. 1928. Neue Ephemeropteren aus Russland // Zoologischer Anzeiger. Bd.75. Hf.11-12. S.319-323.

Tshernova O.A. 1964. [Ephemeroptera] // G.Ya. Bey-Bienko (ed.). Opredelitel' nasekomyh evropeyskoy chasti SSSR. Vol.1.P.110136 [in Russian].

Tshernova O.A., Kluge N.J., Sinitshenkova N.D. \& Belov V.V. 1986. [Ephemeroptera] // Opredelitel' nasekomyh Dalnego Vostoka SSSR, Leningrad: Nauka. Vol.1. P.99-142 [in Russian].

Újhelyi S. 1959. Kérészek Ephemeroptera//Fauna Hungariae. Vol.49. $96 \mathrm{p}$.

Ulmer G. 1939. Eintagsfliegen (Ephemeropteren) von den SundaInseln // Archiv für Hydrobiologie. Supplement 16. S.443-692. Fig. 1-469. 4 tab.

Waltz R.D. 1994. Field recognition of adult Acentrella and Heterocloeon (Ephemeroptera: Baetidae) // Great Lakes Entomologist. Vol.26. No.4. P.321-323.

Waltz R.D. \& McCafferty W.P. 1985. Redescription and new lectotype designation for the type species of Pseudocloeon, $P$. kraepelini Klapalek (Ephemeroptera: Baetidae) // Proceedings of the Entomological Society of Washington. Vol.87. No.4. P.800-804.

Waltz R.D. \& McCafferty W.P. 1987a. New genera of Baetidae for some Nearctic species previously included in Baetis Leach (Ephemeroptera) // Annals of the Entomological Society of America. Vol.80. No.5. P.667-670.

Waltz R.D. \& McCafferty W.P. 1987b. Systematics of Pseudocloeon, Acentrella, Baetiella, and Liebebiella, new genus (Ephemeroptera: Baetidae) // Journal of the New York Entomological Society. Vol.95. No.4. P.553-568.

Weidner H. 1972. Karl und Emil Kraepelin's Studienreise nach Indien und Java im Jahr 1904 // Abhandlungen und Verhandlungen des Naturwissenschaftlichen Vereins in Hamburg. (N.F.). Bd.16. S.19-72.

Wiersema N.A. 2000. A new combination for two North American small minnow mayflies (Ephemeroptera: Baetidae) // Entomological News. Vol.111. No.2. P.140-142.

Zimmermann W. \& Braasch D. 1979. Baetis joosti n.sp., eine neue Eintagsfliege aus Armenien (UdSSR) (Ephemeroptera, Baetidae) // Reichenbachia. Bd.17. Hf.10. S.75-84. http://www.wkap.nl/ $\operatorname{prod} / \mathrm{b} / 1-4020-1974-2$. 